\title{
A Critical Review on the Development of Ionic Liquids-Based Nanofluids as Heat Transfer Fluids for Solar Thermal Energy
}

\author{
Titan C. Paul ${ }^{1, *,+}{ }^{,}$Amitav Tikadar ${ }^{2,+}$, Rajib Mahamud ${ }^{3}$, Azzam S. Salman ${ }^{4}$, A. K. M. Monjur Morshed ${ }^{5}$ \\ and Jamil A. Khan 4 \\ 1 Department of Mathematical Sciences, University of South Carolina Aiken, Aiken, SC 29801, USA \\ 2 The G.W. Woodruff School of Mechanical Engineering, Georgia Institute of Technology, \\ Atlanta, GA 30332, USA; atikadar@gatech.edu \\ 3 Department of Aerospace Engineering, Texas A\&M University, College Station, TX 77843, USA; \\ mahamud@tamu.edu \\ 4 Department of Mechanical Engineering, University of South Carolina, Columbia, SC 29208, USA; \\ asalman@email.sc.edu (A.S.S.); khan@cec.sc.edu (J.A.K.) \\ 5 Department of Mechanical Engineering, Bangladesh University of Engineering \& Technology (BUET), \\ Dhaka 1000, Bangladesh; monjur_morshed@me.buet.ac.bd \\ * Correspondence: titanp@usca.edu \\ + Equal contribution.
}

check for

updates

Citation: Paul, T.C.; Tikadar, A.; Mahmud, R.; Salman, A.S.; Morshed, A.K.M.M.; Khan, J.A. A Critical Review on the Development of Ionic Liquids-Based Nanofluids as Heat Transfer Fluids for Solar Thermal Energy. Processes 2021, 9, 858. https://doi.org/10.3390/pr9050858

Academic Editor: Hussein A. Mohammed

Received: 14 April 2021

Accepted: 30 April 2021

Published: 13 May 2021

Publisher's Note: MDPI stays neutral with regard to jurisdictional claims in published maps and institutional affiliations.

Copyright: (c) 2021 by the authors. Licensee MDPI, Basel, Switzerland. This article is an open access article distributed under the terms and conditions of the Creative Commons Attribution (CC BY) license (https:// creativecommons.org/licenses/by/ $4.0 /)$.

\begin{abstract}
In recent years, solar thermal energy (STE) has attracted energy researchers because of its higher efficacy compared to the photovoltaic solar cell. STE is one of the forms of solar energy whereby heat is transferred via a secondary medium called heat transfer fluids (HTFs). Therefore, the overall performance of STE depends on the thermophysical properties and thermal performance of the HTFs. Traditional HTFs suffer from low decomposition temperature, high melting point, and higher vapor pressure. To overcome these limitations, researchers have recently begun working on new HTFs for STE. Ionic liquids (ILs) are considered as a potential candidate for the next generation of HTFs because of their enhanced thermophysical properties, such as thermal stability at high temperature, insignificant vapor pressure, and high ionic conductivity. In addition, thermophysical properties and thermal performance of ILs can be further enhanced by dispersing nanoparticles, which is one of the emerging research interests to improve the efficiency of the solar thermal system. This paper summarizes the recent study of ILs-based nanofluids as HTFs. These summaries are divided into two sections (i) thermophysical properties studies, such as density, viscosity, thermal conductivity, and heat capacity, and (ii) thermal performance studies such as natural convection and forced convection. Synthesis of ILs-based nanofluids and thermophysical properties measurement techniques are also discussed. Based on these state-of-the-art summaries, we offer recommendations for potential future research direction for ILs-based nanofluids.
\end{abstract}

Keywords: ionic liquids (ILs); ILs-based nanofluids; density; viscosity; specific heat; thermal conductivity; heat transfer coefficient

\section{Introduction}

Environmental and energy-related researchers are continuously working on alternative renewable energy sources and solar energy is already showing its potential as a renewable energy source. There are two forms of solar energy conversion: (i) photovoltaic, where sunlight is directly converted to electricity by using semiconductor and photovoltaic effect, and (ii) solar thermal energy (STE), where sunlight is stored in secondary heat transfer fluids (HTFs) [1]. There are three different fields of study, receiver technology, concentrator design, and advanced high temperature HTFs, used to increase the efficiency of STE [2]. Thermal oil, Therminol VP-1, and molten salts are commonly used as HTFs, however, all of them have their own drawbacks, such as low decomposition temperature, 
high vapor pressure at high temperature, and a higher melting temperature [3]. Therefore, there is an active need for new HTFs for solar thermal applications.

Ionic Liquids (ILs), which are liquid at room temperature and consist of organic cations as well as organic/inorganic anions, gained attention as HTFs because of their excellent thermophysical properties [4]. These properties include negligible vapor pressure and volatility, high thermal stability, low melting point, high ionic conductivity, high solvating capability, and a tendency toward air and moisture stability. Other than in use as HTFs, ILs have many industrial and engineering applications, such as solvents in chemical plants, gas handling, coal processing, and pharmaceuticals, etc. [5-9]. Figure 1 presents the Web of Science [10] report of ILs-related publications, including journals, conferences, patents, and others over the last 20 years.

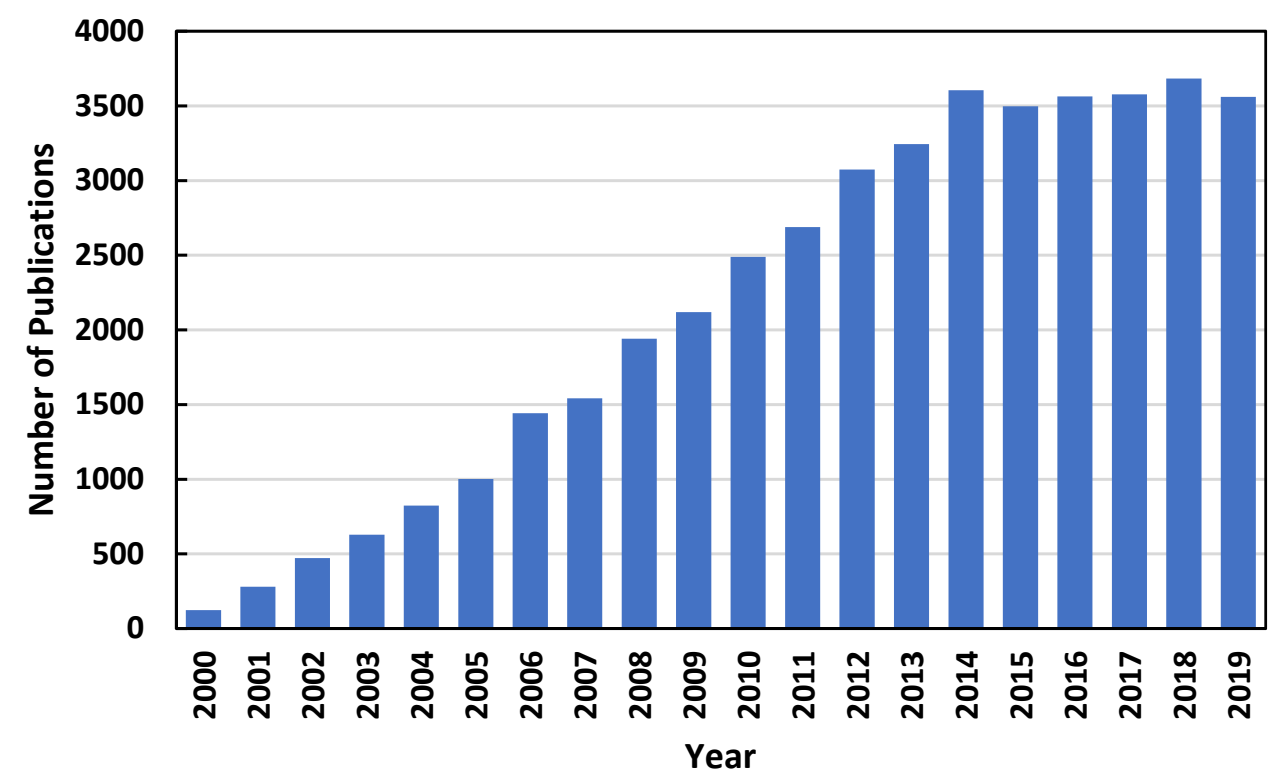

Figure 1. Web of Science record of ionic liquids related publications [10].

Those studies include thermophysical properties, such as melting point, density, viscosity, thermal conductivity, heat capacity, and thermal performance. For example, the melting point of different ILs were studied by Ngo et al. [11] and it was found that with increasing cations size, the melting point of ILs decreases. Another study suggested that cations with a higher chain length have potential for solar cell applications [12]. Murray et al. [13] reported that the increasing alkyl length of cations decreases the density of ILs. Viscosity also increases with the alkyl chain length of cations [14]. Ge et al. [15] experimentally measured the thermal conductivity of ILs within a temperature range of $20^{\circ} \mathrm{C}$ to $80^{\circ} \mathrm{C}$, and found that the thermal conductivity decreases slightly with temperature. Natural convection and forced convection heat transfer performance of different ILs was studied by Paul et al. [16,17]. The convective heat transfer coefficient of ILs is lower than DI-water, whereas the Nusselt number is higher than DI-water because of the higher viscous force and lower thermal conductivity of ILs compared to the DI-water. Moreover, the forced convection behavior of ILs followed the established Shah's and Gnielinski's [18,19] heat transfer correlation for laminar and turbulent flow conditions, respectively. Similar behavior for forced convection heat transfer of 1-butyl-3-methylimidazolium bis (trifluoromethanesulfonyl) imide ([C $\left.\left.\mathrm{C}_{4} \mathrm{mim}\right]\left[\mathrm{NTf}_{2}\right]\right)$ ILs under a laminar flow regime was reported by Chen et al. [20]. He et al. [21] have studied the heat transfer and flow behavior (laminar) of 1-hexyl-3-methylimidazolium tetrafluoroborate $\left(\left[\mathrm{C}_{6} \mathrm{mim}\right]\left[\mathrm{BF}_{4}\right]\right)$ ILs in microfins and smooth tubes, and reported a 5.6\% increment of friction factor, and 5.4-11.3\% enhancement of Nusselt number for finned tubing compare to smooth tube. Wang et al. [22] performed a numerical study of $\left[\mathrm{C}_{4} \mathrm{mim}\right]\left[\mathrm{NTf}_{2}\right]$ ILs flowing through both smooth and corrugated 
tube, and found an increased Nusselt number with an increasing corrugation height to diameter ratio. Wadekar [23] studied the assessment of ILs as a heat transfer fluid in common heat exchangers configurations, and found that ILs have a lower heat transfer coefficient compared to the other HTFs.

Another promising research area is nanofluids, which consist of base fluids such as water or ethylene glycol, and small volume/weight percentage of nanoparticles. Nanofluids have diversified applications, such as industrial cooling, nuclear reactor, extraction of geothermal power, automotive coolant, nanodrug delivery, and sensing and imaging [24]. Figure 2 presents the Web of Science report of nanofluid-related publications, including journal, conference, patents, and other over the last 20 years [10]. Nanofluids have already shown enhanced thermophysical properties [25-29] and thermal performance [30-35]. Enhancement of thermal conductivity and viscosity of nanofluids can be attributed to the Brownian motion, interfacial boundary layer of the nanoparticles, and nanoparticles aggregation [25-29]. The heat transfer coefficient of nanofluids increases in forced convection, which is due to enhanced thermal conductivity, particle migration in the boundary layer, and reduction in boundary layer thickness [30-33]. Conversely, experimental natural convection in nanofluids shows lower heat transfer coefficients compared to base fluids, owing to the sedimentation of nanoparticles on the heated surfaces [34,35]. However, numerical studies of natural convection show enhanced behavior, since in numerical studies the sedimentation effect is not accounted for.

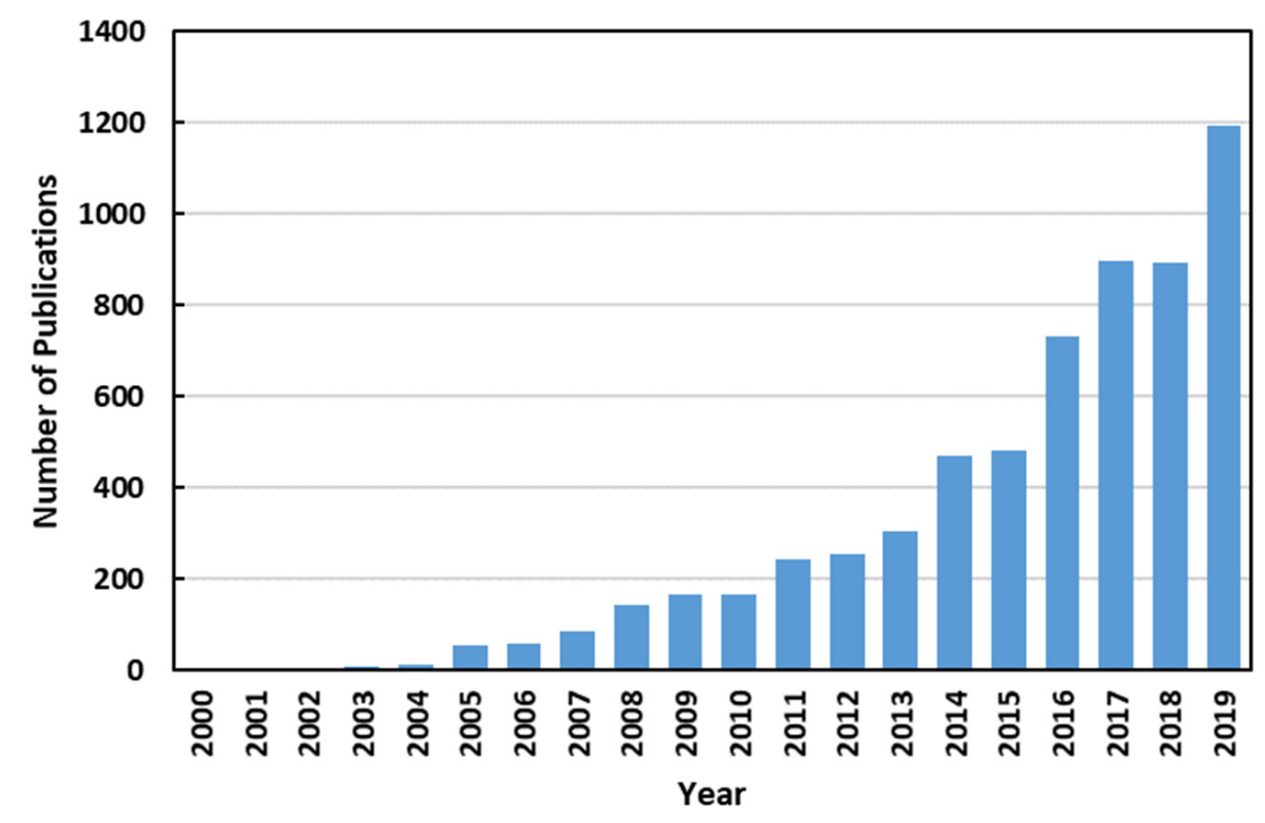

Figure 2. Web of Science record of nanofluids related publications [10].

The concept of nanofluids is used to enhance the thermophysical properties of ionic liquids (ILs) by dispersing a small volume/weight percentage of nanoparticles into base ILs and formed ILs-based nanofluids. Therefore, ILs-based nanofluids have gained interest as HTFs [36-45]. Several research groups are working on ILs-based nanofluids, and to date, several attempts have been made to quantify their thermophysical properties, such as thermal stability, rheological behavior, thermal conductivity, heat capacity, and thermal performance under natural and forced convection conditions.

Bridges et al. [36] studied the density and heat capacity of 1-Butyl-2,3-dimethylimidazo lium bis (trifluoromethylsulfonyl) imide ([C $\mathrm{C}_{4}$ mmim] [NTf $\left.\mathrm{N}_{2}\right]$ ) ILs with $\mathrm{Al}_{2} \mathrm{O}_{3}$ nanoparticles, and reported an enhanced heat capacity. The rheological behavior of $\mathrm{SiO}_{2}$ nanoparticleenhanced ILs was studied by Wittmar et al. [37], and reported that the hydrophobicity of ILs strongly affects the rheological behavior of ILs-based nanofluids. Franca et al. [38] studied the thermal conductivity of $\left[\mathrm{C}_{4} \mathrm{mim}\right]\left[\left(\mathrm{NTf}_{2}\right]\right.$ and $\left[\mathrm{C}_{2} \mathrm{mim}\right]\left[\mathrm{EtSO}_{4}\right] \mathrm{ILs}$ with $0.5 \mathrm{wt} \%$, 
$1 \mathrm{wt} \%$, and $3 \mathrm{wt} \%$ multiwalled carbon nanotubes (MWCNTs). The authors reported a maximum $26 \%$ enhancement of thermal conductivity for $3 \mathrm{wt} \%$ ILs-based nanofluids. Atashrouz et al. [39] developed a mathematical model to characterize the thermal conductivity of ionanofluids using a group method of data handling, and found that the modified geometric mean model better predicts the thermal conductivity of ionanofluids. Chereches et al. [40] studied the thermal conductivity and viscosity of nanodiamond and 1-butyl-3methylimidazolium tetrafluoroborate $\left(\left[\mathrm{C}_{4} \mathrm{mim}\right]\left[\mathrm{BF}_{4}\right]\right)$ ILs-based nanofluids with $0.36 \%$, $0.69 \%$, and $1.04 \%$ volume concentration, respectively. The authors reported a $9.3 \%$ thermal conductivity and $126 \%$ viscosity enhancement for a $1.04 \%$ nanoparticle concentration. Density and heat capacity of $\mathrm{Al}_{2} \mathrm{O}_{3}$ nanoparticles enhanced 1-Ethyl-3-methylimidazolium methanesulfonate $\left[\mathrm{C}_{2} \mathrm{mim}\right]\left[\mathrm{CH}_{3} \mathrm{SO}_{3}\right]$ ILs have been studied by Chereches et al. [41]. The authors concluded that density and heat capacity increases with nanoparticles concentration, and decreases with temperature. Alizadeh et al. [42] experimentally studied the viscosity, electrical conductivity, and surface tension of ILs-based nanofluids. The authors synthesized the ionanofluids by dispersing $1 \mathrm{wt} \%, 2 \mathrm{wt} \%$, and $3 \mathrm{wt} \%$ graphene nanoplatelets with 1-butyl-3-methylimidazolium hexafluorophosphate $\left.\left(\left[\mathrm{C}_{4} \mathrm{mim}\right]\right)\left[\mathrm{PF}_{6}\right]\right)$ ILs, and found that the viscosity and surface tension decreases with temperature and nanoparticles concentration and electrical conductivity increases with temperature and nanoparticles concentration. Joseph et al. [43] investigated the rheological behavior of 1-butyl-4-methylpyridinium chloride ILs-based iron oxide nanofluids, and reported a dendrite-like nanostructure and shear thinning behavior of ILs-based nanofluids. Pamies et al. [44] also reported the non-Newtonian shear thinning behavior of ILs-based nanofluids comprised of 1-ethyl-3-methylimidazolium ([EMIM][DCA]) ILs and $1 \mathrm{wt} \%$ carbon nanotubes (CNTs). Zhang et al. [45] reported a maximum $28.6 \%$ enhancement of thermal conductivity of ILs-based nanofluids containing 1-ethyl-3-methylimidazolium acetate $\left(\left[\mathrm{C}_{2} \mathrm{mim}\right] \mathrm{Ac}\right)$ ILs and $5 \mathrm{wt} \%$ graphene nanoparticles.

Based on the above-mentioned literature, it is clear that ILs-based nanofluids have potential thermophysical properties as HTFs for next generation solar thermal energy systems. There are many studies of ILs-based nanofluids with different combinations of base ILs and nanoparticles. Therefore, there is a need of critical review and future direction of the development of ILs-based nanofluids for solar thermal applications. This paper presents a critical review of the development of ILs-based nanofluids. Here, the reviews are divided into two major sections: (i) thermophysical properties studies (density, thermal conductivity, viscosity, and specific heat), and (ii) thermal performance studies (natural and forced convection). Numerical studies of thermophysical properties and thermal performance are also included.

\section{Synthesis and Thermophysical Property Characterizations of ILs-Based Nanofluids}

\subsection{State-of-the-Art Synthesis Technique}

ILs-based nanofluids are prepared by dispersing small amounts of nanoparticles into base ionic liquids (ILs), and, as seen in all of the studied literature, use the two-steps method [46] (see Figure 3). In the two-steps method, nanoparticles are prepared first in powder form, then dispersed into the base ILs. The preparation of ILs-based nanofluids was mainly done by vortex mixture or sonification to reduce possible agglomeration of nanoparticles.

Table 1 represents all the studied base ILs, while Table 2 represents the summary of studied ILs-based nanofluids with their nanoparticles concentrations. 


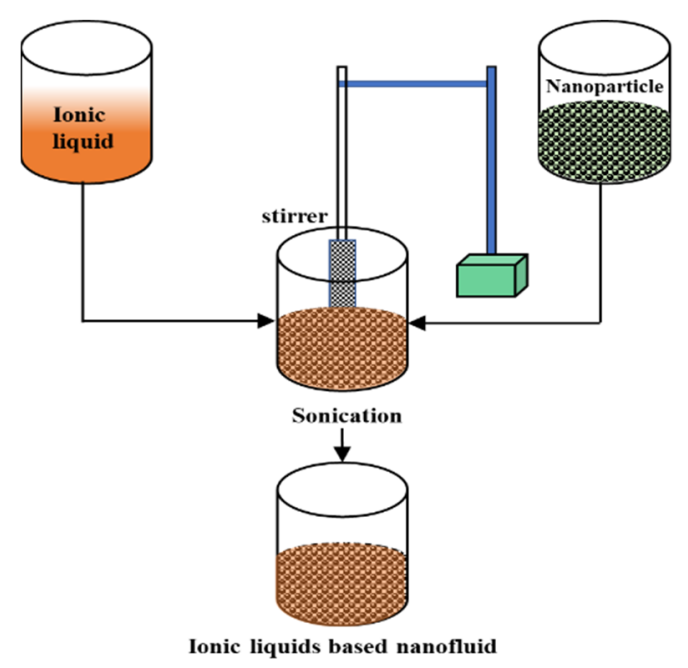

Figure 3. Schematic of two-steps method of ILs-based nanofluids preparation.

Table 1. List of the studied ionic liquids.

\begin{tabular}{|c|c|}
\hline Ionic Liquids & Abbreviations \\
\hline 1-butyl-2,3-dimethylimidazolium bis(trifluoromethylsulfonyl)imide & {$\left[\mathrm{C}_{4} \mathrm{mmim}_{[}\left[\mathrm{NTf}_{2}\right]\right.$} \\
\hline 1-butyl-3-methylimidazolium bis(trifluoromethanesulfonyl)imide & {$\left[\mathrm{C}_{4} \mathrm{mim}\right]\left[\left[\mathrm{NTf}_{2}\right]\right.$} \\
\hline 1-butyl-3-methylimidazolium hexafluorophosphate & {$\left[\mathrm{C}_{4} \mathrm{mim}\right]\left[\mathrm{PF}_{6}\right]$} \\
\hline 1-Butyl-3-methylimidazolium tetrafluoroborate & $\left.\left[\mathrm{C}_{4} \mathrm{mim}\right]\left[\mathrm{BF}_{4}\right]\right)$ \\
\hline N-butyl-N-methylpyrrolidiniumbis\{trifluoromethyl)sulfonyl\} imide & {$\left[\mathrm{C}_{4} \mathrm{mpyrr}\right]\left[\mathrm{NTf}_{2}\right]$} \\
\hline 1-butyl-3-methylimidazolium dicyanamide & {$\left[\mathrm{C}_{4} \mathrm{mim}\right][\mathrm{Dca}]$} \\
\hline 1-butyl-3-methylimidazolium trifluoromethanesulfonate & {$\left[\mathrm{C}_{4} \mathrm{mim}\right]\left[\mathrm{CF}_{3} \mathrm{SO}_{3}\right]$} \\
\hline 1-n-butyl-3-methyl-imidazolium thiocyanate & {$\left[\mathrm{C}_{4} \mathrm{mim}\right][\mathrm{SCN}]$} \\
\hline $\mathrm{N}$-butyl-N,N,N-trimetylammonium bis(trifluorme thylsulfonyl)imide & {$\left[\mathrm{N}_{4111}\right]\left[\mathrm{NTf}_{2}\right]$} \\
\hline 1-ethyl-3-methylimidazolium ethylsulfate & {$\left[\mathrm{C}_{2} \mathrm{mim}\right]\left[\mathrm{EtSO}_{4}\right]$} \\
\hline 1-ethyl-3-methylimidazolium methanesulfonate & {$\left[\mathrm{C}_{2} \mathrm{mim}\right]\left[\mathrm{CH}_{3} \mathrm{SO}_{3}\right]$} \\
\hline 1-ethyl-3-methylimidazolium dicyanamide & {$\left[\mathrm{C}_{2} \mathrm{mim}\right][\mathrm{DCA}]$} \\
\hline 1-ethyl-3-methylimidazolium acetate & {$\left[\mathrm{C}_{2} \mathrm{mim}\right] \mathrm{Ac}$} \\
\hline 1-ethyl-3-methylimidazolium diethylphosphate & {$\left[\mathrm{C}_{2} \mathrm{mim}\right][\mathrm{DEP}]$} \\
\hline 1-ethyl-3-methyl-imidazolium thiocyanate & {$\left[\mathrm{C}_{2} \mathrm{mim}\right][\mathrm{SCN}]$} \\
\hline 1-ethyl-3-methylimidazolium ethylsulfate & {$\left[\mathrm{C}_{2} \mathrm{mim}\right]\left[\mathrm{C}_{2} \mathrm{SO}_{4}\right]$} \\
\hline 1-ethyl-3-methyl-imidazolium tricyanomethanide & {$\left[\mathrm{C}_{2} \mathrm{mim}\right]\left[\mathrm{C}(\mathrm{CN})_{3}\right]$} \\
\hline 1-hexyl-3-methylimidazolium bis(trifluoromethylsulfonil)imide & {$\left[\mathrm{C}_{6} \mathrm{mim}\right]\left[\mathrm{NTf}_{2}\right]$} \\
\hline 1-hexyl-3-methylimidazolium tetrafloroborate & {$\left[\mathrm{C}_{6} \mathrm{mim}\right]\left[\mathrm{BF}_{4}\right]$} \\
\hline 1-hexyl-3-methylimidazolium hexafluorophosphate & {$\left[\mathrm{C}_{6} \mathrm{mim}\right]\left[\mathrm{PF}_{6}\right]$} \\
\hline 1-propyl-3-methylimidazolium Iodide & [PMII] \\
\hline Trihexyltetradecylphosphonium dicyanamide & {$\left[\mathrm{P}_{66614}\right]\left[\mathrm{N}-(\mathrm{CN})_{2]}\right.$} \\
\hline Trihexyltetradecylphosphonium bromide & {$\left[\mathrm{P}_{66614}\right][\mathrm{Br}]$} \\
\hline
\end{tabular}


Table 2. Summary of ionic liquids-based nanofluids.

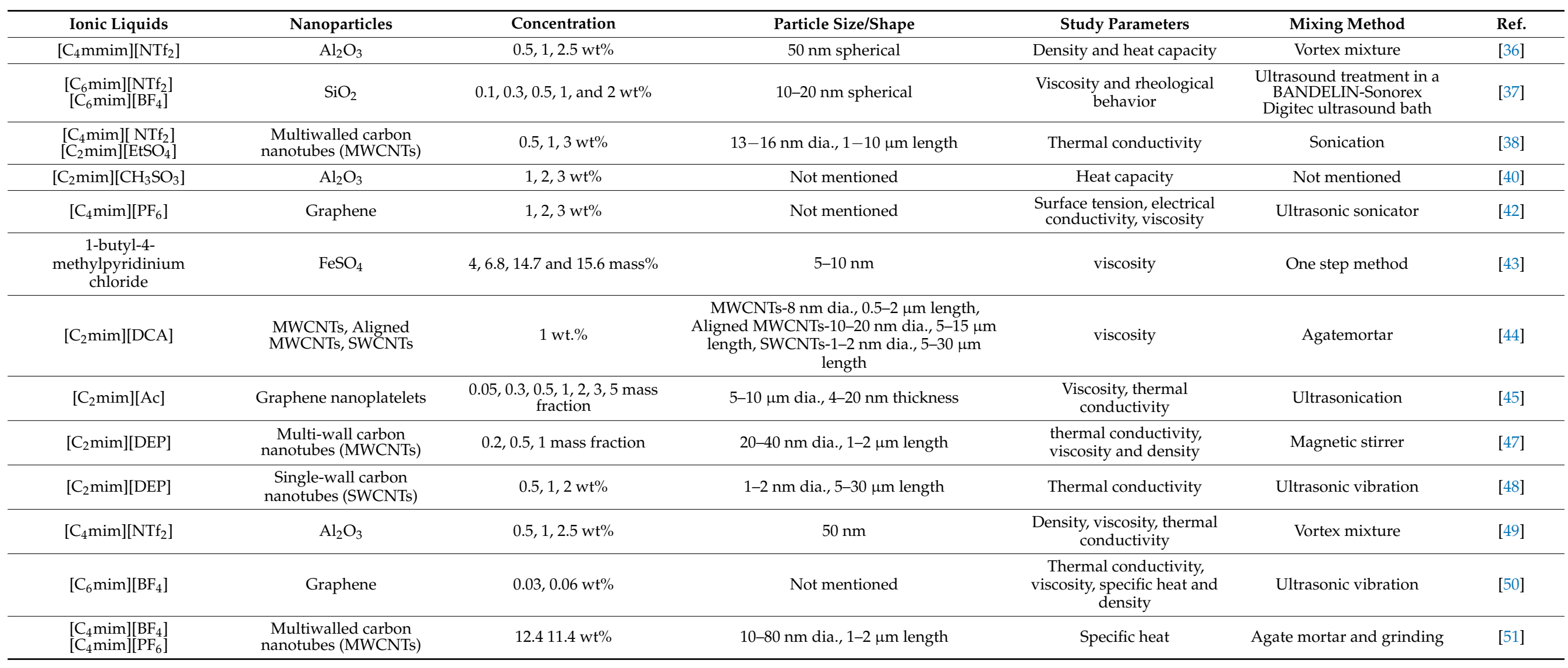


Table 2. Cont.

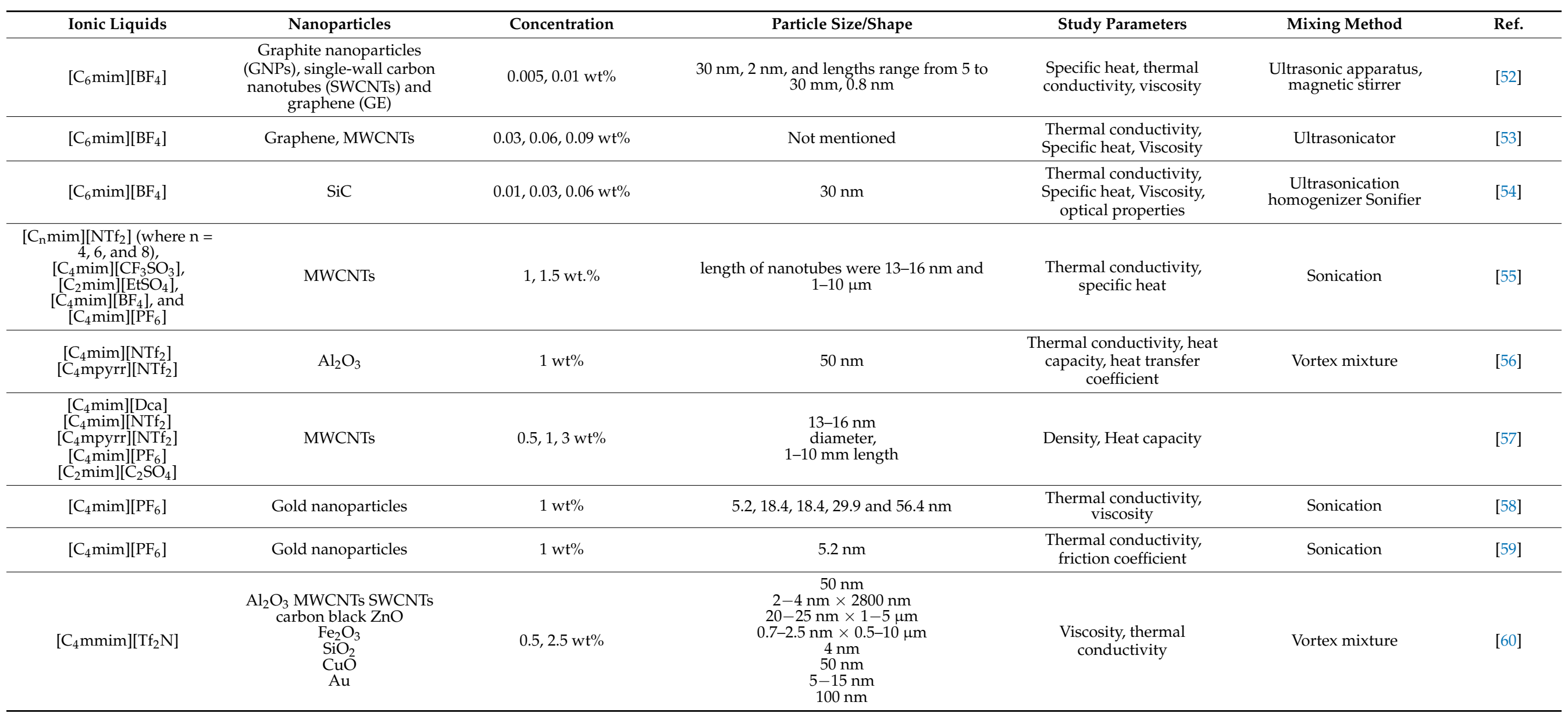


Table 2. Cont

\begin{tabular}{|c|c|c|c|c|c|c|}
\hline Ionic Liquids & Nanoparticles & Concentration & Particle Size/Shape & Study Parameters & Mixing Method & Ref. \\
\hline $\begin{array}{c}{\left[\mathrm{C}_{6} \operatorname{mim}\right]\left[\mathrm{BF}_{4}\right]} \\
{\left[\mathrm{C}_{4} \mathrm{mim}\right]\left[\mathrm{PF}_{6}\right]} \\
{\left[\mathrm{C}_{6} \mathrm{mim}\right]\left[\mathrm{PF}_{6}\right]} \\
{\left[\mathrm{C}_{4} \mathrm{mim}\right]\left[\mathrm{CF} \mathrm{SO}_{3}\right]} \\
{\left[\mathrm{C}_{4} \mathrm{mpyrr}\right]\left[\mathrm{NTF}_{2}\right]}\end{array}$ & MWCNTs & $1,1.5 \mathrm{wt} \%$ & $13-16 \mathrm{~nm}$ dia., $1-10 \mathrm{~mm}$ length & $\begin{array}{l}\text { Thermal conductivity, heat } \\
\text { capacity }\end{array}$ & Sonication & [61] \\
\hline $\begin{array}{c}{\left[\mathrm{C}_{4} \mathrm{mim}\right]\left[\mathrm{NTf}_{2}\right]} \\
{\left[\mathrm{C}_{4} \mathrm{mpyrr}\right]\left[\mathrm{NTf}_{2}\right]} \\
{\left[\mathrm{N}_{4111}\right]\left[\mathrm{NTf}_{2}\right]} \\
{\left[\mathrm{C}_{4} \mathrm{mmim}_{2}\right]\left[\mathrm{NTf}_{2}\right]}\end{array}$ & $\mathrm{Al}_{2} \mathrm{O}_{3}$ & $0.5,1,2.5 \mathrm{wt} \%$ & $50 \mathrm{~nm}$ & $\begin{array}{c}\text { Viscosity, thermal } \\
\text { conductivity, heat capacity }\end{array}$ & Vortex mixture & [62] \\
\hline $\begin{array}{c}{\left[\mathrm{P}_{66614}\right]\left[\mathrm{N}-(\mathrm{CN})_{2}\right]} \\
{\left[\mathrm{P}_{66614}\right][\mathrm{Br}]} \\
{\left[\mathrm{C}_{2} \mathrm{mim}\right][\mathrm{SCN}]} \\
{\left[\mathrm{C}_{4} \mathrm{mim}\right][\mathrm{SCN}]} \\
{\left[\mathrm{C}_{2} \mathrm{mim}\right]\left[\mathrm{C}(\mathrm{CN})_{3}\right]} \\
{\left[\mathrm{C}_{4} \mathrm{mim}\right]\left[\mathrm{C}(\mathrm{CN})_{3}\right]}\end{array}$ & MWCNTs & $0.5,1 \mathrm{wt} \%$ & 13-16 nm dia., $1-10 \mathrm{~mm}$ length & Thermal conductivity & Sonication & [63] \\
\hline$\left[\mathrm{C}_{4} \mathrm{mim}\right]\left[\mathrm{BF}_{4}\right]$ & Modified graphene & $\begin{array}{c}0.01 \%, 0.03 \% \text { and } 0.05 \% \\
\text { wt } \%\end{array}$ & Not mentioned & $\begin{array}{l}\text { Thermal conductivity, } \\
\text { Radiative properties }\end{array}$ & Mildly stirring & [64] \\
\hline$\left[\mathrm{C}_{4} \mathrm{mim}\right]\left[\mathrm{PF}_{6}\right]$ & MWCNTs & $0.05,0.1 \mathrm{wt} \%$ & Diameter, $20-40 \mathrm{~nm}$; length, 5-15 $\mu \mathrm{m}$ & Thermal conductivity & & [65] \\
\hline $\begin{array}{c}\left.\left[\left(\mathrm{C}_{6}\right)_{3} \mathrm{PC}_{14}\right)\right] \\
{[\mathrm{Phosph}]} \\
\left.\left[\left(\mathrm{C}_{4}\right)_{3} \mathrm{PC}_{1}\right)\right] \\
{\left[\mathrm{C}_{1} \mathrm{SO}_{4}\right]} \\
{\left[\left(\mathrm{C}_{6}\right)_{3} \mathrm{PC}_{14}\right]} \\
{\left[\mathrm{NTf}_{2}\right]}\end{array}$ & MWCNTs & $0.1,0.2 \mathrm{wt} \%$ & 13-16 $\mathrm{nm}$ dia., $1-10 \mathrm{~mm}$ length & $\begin{array}{l}\text { Thermal conductivity, } \\
\text { viscosity, heat capacity, } \\
\text { thermal stability }\end{array}$ & Sonication & [66] \\
\hline$\left[\mathrm{C}_{4} \mathrm{mim}\right]\left[\mathrm{PF}_{6}\right]$ & $\begin{array}{l}\text { Functionalized multiwalled } \\
\text { carbon nanotubes } \\
\text { (F-MWCNTs) }\end{array}$ & $0.01,0.02,0.04,0.06 \mathrm{wt} \%$ & $\begin{array}{l}\text { Diameter, } 20-40 \mathrm{~nm} ; \\
\text { length, } 5-15 \mu \mathrm{m}\end{array}$ & Viscosity & Ultrasonication & [67] \\
\hline [PMII] & MWCNTs & $0.1 \mathrm{wt} \%$ & $\begin{array}{l}\text { Outer diameter of } 8-15 \mathrm{~nm} \text {, inner diameter } \\
\text { of } 3-5 \mathrm{~nm} \text {, length of approximately } 50 \mu \mathrm{m}\end{array}$ & Viscosity & Not mentioned & [68] \\
\hline
\end{tabular}




\subsection{Experimental Measurements, and Theoretical and Empirical Correlation}

Density of ILs-based nanofluids is generally measured by using specific gravity balance [47], pycnometer [49], and Anton Paar DMA $4500 \mathrm{M}$ densitometer [57] within the temperature range of $298.15 \mathrm{~K}$ to $323.15 \mathrm{~K}, 283.15$ to $343.15 \mathrm{~K}$, and 298.15 to $363.15 \mathrm{~K}$, respectively. However, mixing theory [69] can be used to theoretically calculate the effective density of ILs-based nanofluids:

$$
\rho_{I N F}=\phi \rho_{n}+(1-\phi) \rho_{B L}
$$

where $\rho_{I N F}, \rho_{n}$, and $\rho_{B L}$ are the density of ILs-based nanofluids, nanoparticles, and base fluid, respectively, and $\phi$ is the nanoparticles' volume fraction.

The thermal conductivity of ILs-based nanofluids can be measured by using a KD2 pro thermal property analyzer (Decagon Device, Inc., Pullman, USA and Labcell Ltd., Alton, UK), [38,49,54-56,58-66], thermal conductivity measuring instrument TC 3010L (Xian Xiatech Co., Ltd., Xian, China) $[47,48]$, and thermal constants analyzer (Hot Disk TPS 2500S, Hot Disk AB, Sweden) [50,52,53]. The KD2 pro and TC 3010L operate based on the principle of the transient hot-wire method, while the Hot Disk TPS 2500S uses the transient plane source (TPS) method.

Aside from this, different theoretical models were considered by many researchers to calculate the thermal conductivity of ILs-based nanofluids. All of the used and proposed theoretical models and empirical correlations are listed in Tables 3 and 4, respectively.

Table 3. Commonly used theoretical models to calculate the effective thermal conductivity of ILs-based nanofluids.

\begin{tabular}{|c|c|c|}
\hline Models & Equations & Ref. \\
\hline Maxwell model [70] & $\frac{k_{I N F}}{k_{B L}}=\frac{k_{n}+2 k_{B L}-2 \phi\left(k_{B L}-k_{n}\right)}{k_{n}+2 k_{B L}+\phi\left(k_{B L}-k_{n}\right)}$ & {$[54,61,62,64,71]$} \\
\hline $\begin{array}{l}\text { Hamilton and Crosser } \\
\text { model [72] }\end{array}$ & $\frac{k_{I N F}}{k_{B L}}=\frac{k_{n}+(\alpha-1) k_{B F}-(\alpha-1)\left(k_{B F}-k_{n}\right) \phi}{k_{n}+(\alpha-1) k_{B F}+\left(k_{B F}-k_{n}\right) \phi}$ & {$[47,52,63,65,73]$} \\
\hline Bruggeman model [74] & $k_{I N L}=\frac{1}{4}\left[(3 \phi-1) k_{n}+(2-3 \phi) k_{B L}\right]+\frac{k_{B L}}{4} \sqrt{\Delta} \Delta=\left[(3 \phi-1)^{2}\left(\frac{k_{n}}{k_{B L}}\right)^{2}+(2-3 \phi)^{2}+2\left(2+9 \phi-9 \phi^{2}\right)\left(\frac{k_{n}}{k_{B L}}\right)\right]$ & {$[62]$} \\
\hline Aggregation model [75] & $\begin{array}{c}\frac{k_{I N F}}{k_{B L}}=\frac{k_{a}+2 k_{B L}-2 \phi_{a}\left(k_{B L}-k_{a}\right)}{k_{a}+2 k_{B L}+\phi_{a}\left(k_{B L}-k_{a}\right)} \\
\frac{k_{a}}{k_{B L}}=\frac{1}{4}\left\{\left(3 \phi_{i n}-1\right) \frac{k_{n}}{k_{B L}}+\left(3\left(1-\phi_{i n}\right)-1\right)+\left[\left(\left(3 \phi_{i n}-1\right) \frac{k_{n}}{k_{B L}}+\left(3\left(1-\phi_{i n}\right)-1\right)\right)^{2}+8 \frac{k_{n}}{k_{B L}}\right]^{1 / 2}\right\} \\
\text { where } \phi_{i n}\left(=\left(\frac{a_{a}}{a}\right)^{D-3}\right)\end{array}$ & [62] \\
\hline Interfacial layer [76] & $\begin{array}{c}k_{I N F}=\frac{\left(k_{n}-k_{l r}\right) \phi k_{l r}\left[2 \gamma_{1}^{2}-\gamma^{2}+1\right]+\left(k_{n}+2 k_{l r}\right) \gamma_{1}^{2}\left[\phi \gamma^{2}\left(k_{l r}-k_{B L}\right)+k_{B L}\right]}{\gamma_{1}^{2}\left(k_{n}+2 k_{l r}\right)-\left(k_{n}-k_{l r}\right) \phi\left[\gamma_{1}^{2}+\gamma^{2}-1\right]} \\
\text { where } k_{B L}<k_{l r}<k_{n} ; \text { here } k_{l r}=3 k_{B L} \text { considered. } \\
\gamma=1+\frac{h}{a} \gamma_{1}=1+\frac{h}{2 a}\end{array}$ & $\begin{array}{l}{[47,55,61-} \\
63,66,73]\end{array}$ \\
\hline
\end{tabular}

Table 4. Empirical correlations of effective thermal conductivity of ILs-based nanofluids.

\begin{tabular}{cc}
\hline Equations & Ref. \\
\hline$k_{I N F}=k_{B L}\left(1+C_{1} \phi+C_{2} \phi^{2}\right)$ & {$[71]$} \\
Where $C_{1}=4.36 \pm 0.11, C_{2}=-248.55 \pm 10.44$ & {$[49]$} \\
\hline$\frac{k_{I N F}}{k_{B L}}=12.496 \phi+1$ & {$[65]$} \\
\hline$\frac{k_{I N F}}{k_{B L}}=7.3 \phi+1$ & {[}
\end{tabular}

The viscosity of ILs-based nanofluids is commonly measured by using an Anton Paar Rheometer Physica MCR 301 [37], Brookfield-DVII+Pro [42], HAAKE MARS 2 rheometer (Thermo Fisher Scientific, Karlsruhe, Germany) [43], AR-G2 rotational rheometer from TA instruments (New Castle, Delaware, USA) [44], Viscotester iQ, Haake, Germany [45], capillary viscometer [47], cone and plate type rotary viscometer [49,53,54,62], viscometer (DVI, Brookfield, Middleboro, MA, USA) [50,52], HAAKE RS6000 (Germany) Rheometer [58], 
and controlled stress rheometer (Haake model RS1) [60]. It is worth noting that most of the viscosity measuring units have a cone and plate type arrangement.

Additionally, different theoretical models were considered by many researchers to calculate the viscosity of ILs-based nanofluids, and all of the used theoretical models and empirical correlations are listed in the Tables 5 and 6, respectively.

Table 5. Theoretical models of the effective viscosity of ILs-based nanofluids.

\begin{tabular}{ccc}
\hline Models & Equations & Ref. \\
\hline Einstein model [77] & $\frac{\mu_{I N F}}{\mu_{B L}}=1+2.5 \phi$ & {$[45,62]$} \\
\hline Brinkman model [78] & $\frac{\mu_{I N F}}{\mu_{B L}}=\frac{1}{(1-\phi)^{2.5}}$ & {$[45,47,62]$} \\
\hline Batchelor model [79] & $\frac{\mu_{I N F}}{\mu_{B L}}=6.5 \phi^{2}+2.5 \phi+1$ & {$[45,54,62]$} \\
\hline Nielson [80] & $\begin{array}{c}\frac{\mu_{I N F}}{\mu_{B L}}=(1+1.5 \phi) e^{\frac{\phi}{(1-\phi m)}} \\
\text { where } \phi_{m} \text { is the maximum particle packing } \\
\text { fraction which is typically considered 0.605. }\end{array}$ & {$[62]$} \\
\hline $\begin{array}{c}\text { Krieger-Dougherty (K-D) } \\
\text { model [81] }\end{array}$ & $\begin{array}{c}\frac{\mu_{I N F}}{\mu_{B L}}=\left(1-\frac{\phi}{0.605}\left(\frac{a_{a}}{a}\right)^{1.2}\right)^{-1.5125} \\
\text { where, } a_{a} \text { and } a \text { are the average radii of the } \\
\text { aggregate and primary nanoparticles, } \\
\text { respectively. }\end{array}$ & {$[62]$} \\
\hline & \multicolumn{2}{c}{} \\
\hline
\end{tabular}

Table 6. Empirical correlations of effective viscosity of ILs-based nanofluids.

\begin{tabular}{cc}
\hline Equations & Ref. \\
\hline$\frac{\mu_{I N F}}{\mu_{B L}}=1.1 \phi+1$ & {$[45]$} \\
\hline$\frac{\mu_{I N F}}{\mu_{B L}}=19088 \phi^{2}+3.733 \phi+1$ & {$[49]$} \\
\hline
\end{tabular}

Heat capacity of ILs-based nanofluids is commonly measured by using differential scanning calorimeter equipment, such as the DSC Q2000 [40,56,62], DSC, Q20 [50,52,53], TA Instruments, thermal analyzer (DSC823, Mettler-Toledo, Switzerland) [54], differential scanning calorimeter (DSC-111, Setaram, Lyon, France) [55,61], differential scanning calorimeter equipment, and Q100 TA instruments $[57,66]$. In all the techniques, the heating rate is $10^{\circ} \mathrm{C} / \mathrm{min}$. Additionally, to date, two different groups have proposed two different models to theoretically predict the heat capacity of ILs-based nanofluids as summarized in Table 7.

Table 7. Theoretical models of the heat capacity of ILs-based nanofluids.

\begin{tabular}{ccc}
\hline Models & Equations & Ref. \\
\hline Pak and Cho [82] & $C_{p, I N F}=\phi C_{p, n}+(1-\phi) C_{p, B L}$ & {$[41]$} \\
\hline Xuan and Roetzel [83] & $c_{p, I N F}=\frac{(1-\phi) \rho_{B L} C_{p, B L}+\phi \rho_{n} C_{p, n}}{(1-\phi) \rho_{B L}+\phi \rho_{n}}$ & {$[41,57,62,66]$} \\
\hline
\end{tabular}

\section{Literature Survey of Thermophysical Properties of ILs-Based Nanofluids}

\subsection{Density}

Although density has significant effect on the thermal-hydraulic characteristics of ILsbased nanofluids in terms of pumping power, especially for forced convection heat transfer, unfortunately, most researchers have ignored density in their studies to date. This can be attributed to the less significance of density toward the thermal performance of ILs-based nanofluids, less temperature dependency, and also the accurate prediction capabilities of some well-established rules for mixtures of ILs-based nanofluids' density. Xie et al. [47] 
studied the density variation of the aqueous solution of the $\left[\mathrm{C}_{2} \mathrm{mim}\right][\mathrm{DEP}]$ along with multi-wall carbon nanotubes [MWCNTs]. Paul et al. [84] and Chereches et al. [85] also experimentally studied the density of ILs-based nanofluids for $\left[\mathrm{C}_{4} \mathrm{mpyrr}\right]\left[\mathrm{NTf}_{2}\right]$ and $\left[\mathrm{C}_{2}\right.$ mim] $\left[\mathrm{CH}_{3} \mathrm{SO}_{3}\right] \mathrm{ILs}$ and $\mathrm{Al}_{2} \mathrm{O}_{3}$ nanoparticles, respectively. It is worth mentioning that the density of the ILs-based nanofluids were higher than the pure ILs because of the higher density of MWCNTs and $\mathrm{Al}_{2} \mathrm{O}_{3}$ nanoparticles when compared to base ILs. Moreover, from Figure 4, it can be seen that the density of the ILs-based nanofluids decrease with increasing temperature, regardless of the nanoparticle concentration. The effect of single-wall carbon nanotubes (SWCNTs) on the density of aqueous [ $\left.\mathrm{C}_{2} \mathrm{mim}\right][\mathrm{DEP}]$ were numerically studied by Li et al. [62]. Although the authors reported the same trend in density for SWCNTs as MWCNTs, but interestingly in case of SWCNT, the ILs density was less than the MWCNT dispersed ILs, even at higher concentration of the SWCNT.

The effect of ruthenium $(\mathrm{Ru})$ nanoparticles on the density of ILs having 1-Butyl3-methyl imidazolium cation $\left[\mathrm{C}_{4} \mathrm{mim}\right]^{+}$within a temperature range of $20{ }^{\circ} \mathrm{C}$ to $70{ }^{\circ} \mathrm{C}$ was experimentally studied by Patil et al. [86]. The experimental data showed a gradual reduction of the densities of the ILs-based nanofluids while temperature increased. On the contrary, unusual reduction of densities were reported with small increment of the $\mathrm{Ru}$ nanoparticles concentration. Liu et al. [64] studied graphene (GE)-dispersed nanofluids based on the $\left[\mathrm{C}_{4} \mathrm{mim}\right]\left[\mathrm{BF}_{4}\right]$ for a wide range of the working temperature. The authors claimed that the density of the ILs decreases with the increase in the temperature and mass fraction of GE. This tendency can be explained by the lower density of GE when compared to the base ILs. Similar behavior in density variation was also reported by Shevelyova et al. [51] for the nanofluids comprised of $\left[\mathrm{C}_{4} \mathrm{mim}\right]\left[\mathrm{BF}_{4}\right],\left[\mathrm{C}_{4} \mathrm{mim}\right]\left[\mathrm{PF}_{6}\right] \mathrm{ILs}$ and MWCNTs.

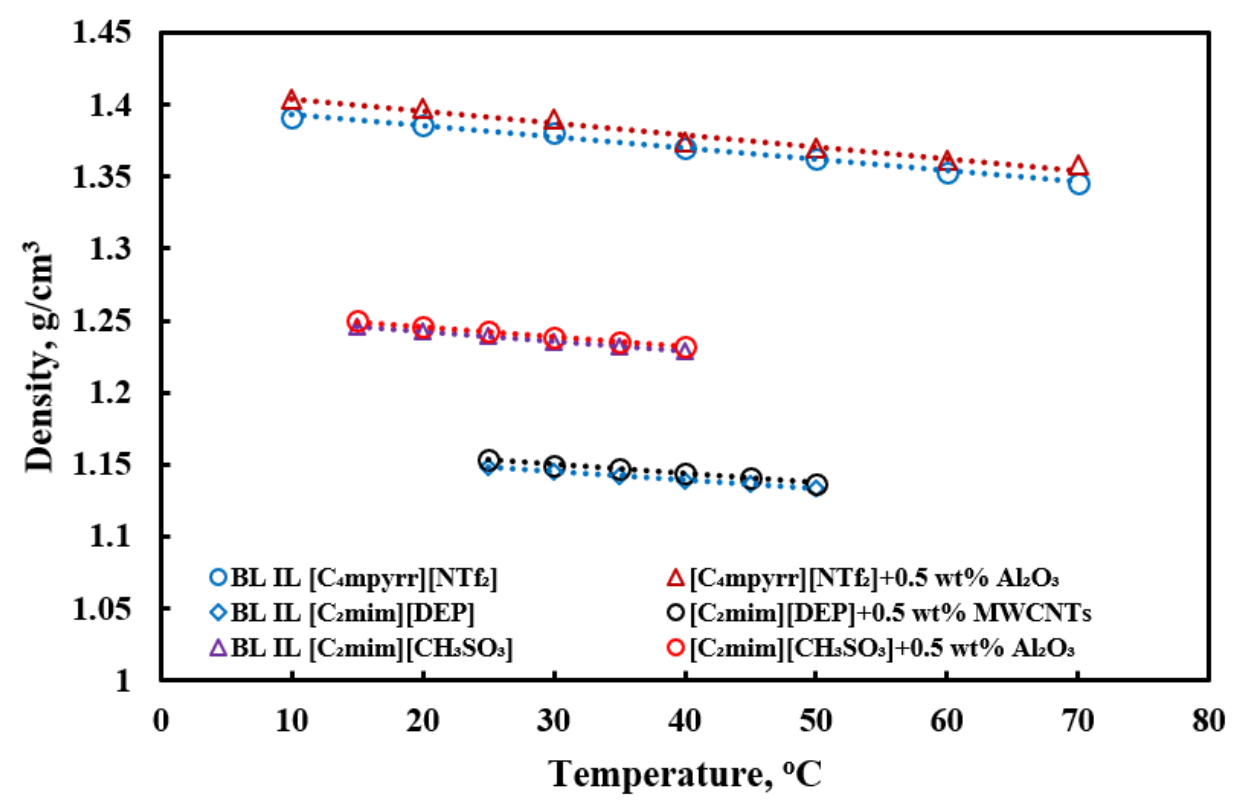

(a)

Figure 4. Cont. 


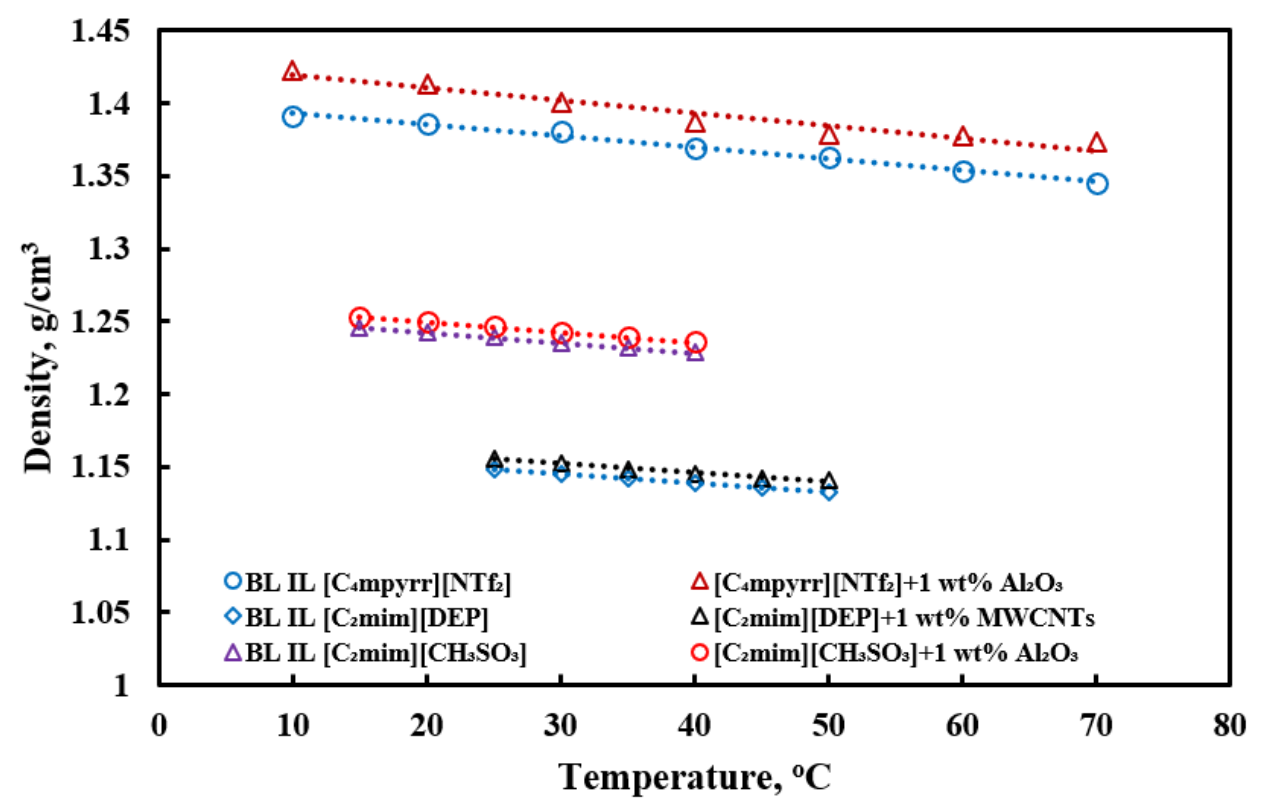

(b)

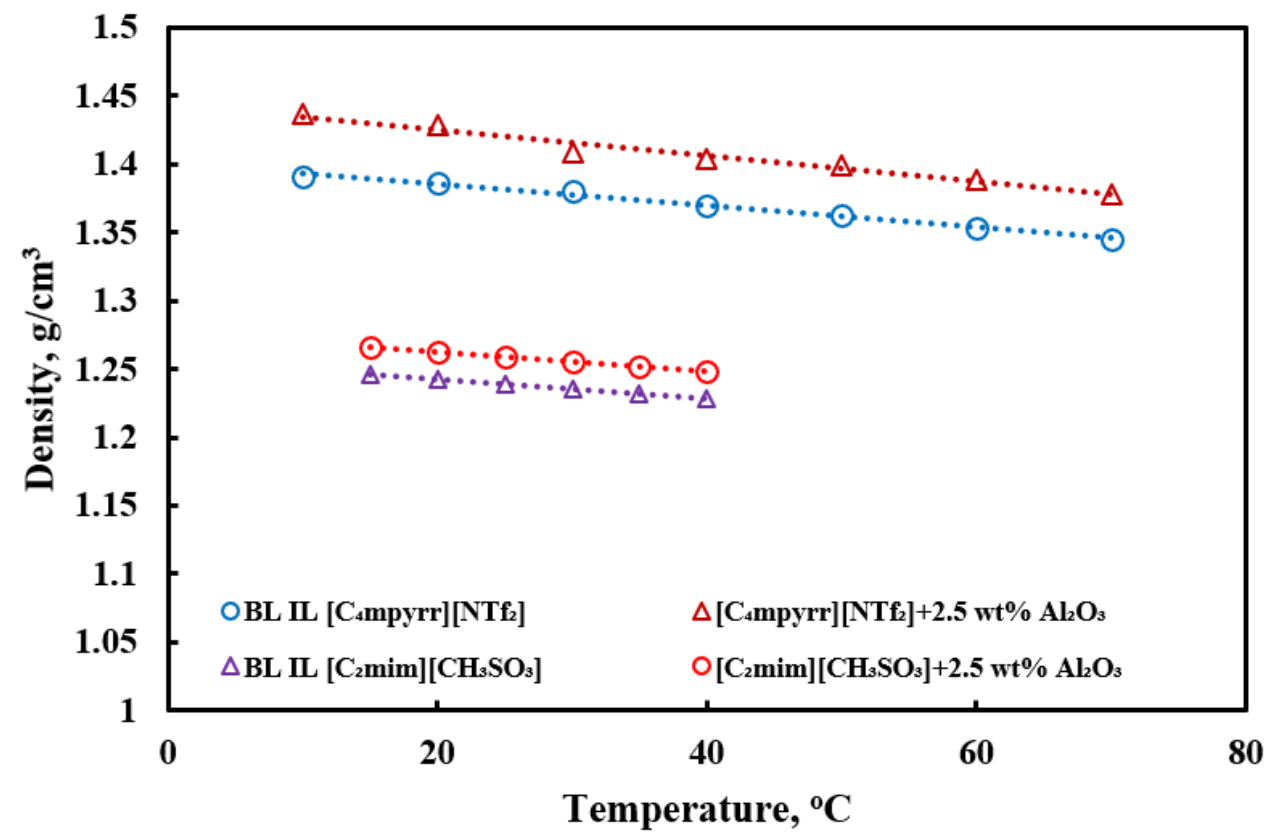

(c)

Figure 4. Density of base IL and ILs-based nanofluids as a function of temperature at the different nanoparticle concentrations (a) $0.5 \mathrm{wt} \%$, (b) $1 \mathrm{wt} \%$, and (c) $2.5 \mathrm{wt} \%$ [47,84,85]. Reproduced with permission from [Xie, Chereches, and Paul], [Chin. J. Chem. Eng., 2016, Int. J. Heat Mass Transf. 2015, J. Mol. Liq. 2019]; published by [Elsevier].

\subsection{Specific Heat}

One of the major applications of ILs in solar collectors is to store and transport thermal energy. Therefore, to ensure the effective use of ILs-based nanofluids in such applications, an in depth understanding of the specific heat of the ILs and also the effects of the nanoparticles on the base fluid's specific heat is desired. To date, numerous research works have been performed to address the characteristics of the specific heat of ILs-based nanofluids. For example, Zhang et al. [52] experimentally studied the $\left[\mathrm{C}_{4} \mathrm{mim}\right]\left[\mathrm{BF}_{4}\right]-$ based ILs along with the graphite nanoparticles (GNPs), single-wall carbon nanotubes (SWCNTs), and graphene (GE). The authors considered two different concentrations of all nanoparticles, such as 0.005 and $0.01 \mathrm{wt} \%$, and conducted an experiment within a 
temperature range of $30{ }^{\circ} \mathrm{C}-150{ }^{\circ} \mathrm{C}$. From Figure 5, it can be observed that specific heat of the ILs-based nanofluids containing the carbon nanomaterials is lower than that of the base liquid at any specific temperature. Although the underlying mechanism of this behavior is not yet fully explained/understood, the authors mainly identified the lower specific heat of the bulk carbon material compared to the pure ILs at the room temperature as the probable reason of this behavior. Additionally, from Figure 5, it can also be seen that the reduction in specific heat of GNPs-dispersed ILs is much lower than the SWCNTS and GE-dispersed ILs. This can be attributed to the fact that the zero-dimensional GNPs have higher thermal energy density than the two-dimensional GE and the one-dimensional SWCNTs. The gradual increment in specific heat is evident for all ILs-based nanofluids with temperature increment from $30^{\circ} \mathrm{C}$ to $140{ }^{\circ} \mathrm{C}$. Interestingly, due to the phase transition behavior of the ILs at temperatures above $140{ }^{\circ} \mathrm{C}$, a slight decline in specific heat of the ILs-based nanofluids was reported.

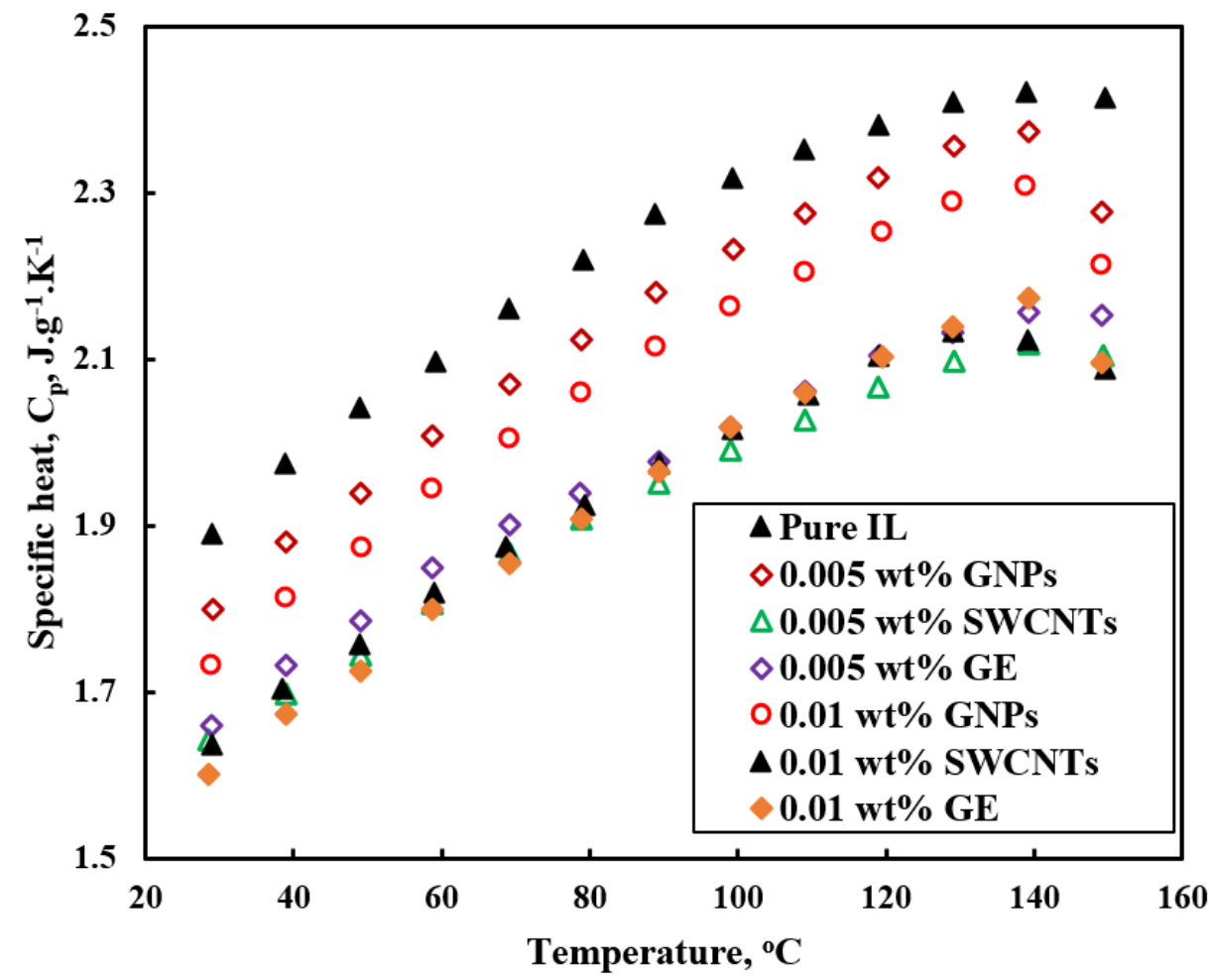

Figure 5. Variation of specific heat of $\left[\mathrm{C}_{4} \mathrm{mim}\right]\left[\mathrm{BF}_{4}\right]$ and the ILs-based nanofluids containing different carbon nanomaterials at the mass fractions of $0.005 \%$ and $0.01 \%$ as a function of temperature [52]. Reproduced with permission from [Zhang], [Renew. Energy]; published by [Elsevier], 2016.

Experimental investigation of the specific heat of the composition of graphene (GE) and [HMIM][BF4] was conducted by Liu et al. [50] for two different concentrations of GE $(0.03$ and $0.06 \mathrm{wt} \%)$ as well as for a wide temperature range of $25^{\circ} \mathrm{C}$ to $215^{\circ} \mathrm{C}$. The specific heat showed a sinusoidal behavior with the temperature's increment regardless of the mass fraction of nanoparticles as shown in Figure 6. It can also be seen that for higher concentrations of GE, the specific heat reduced significantly compared to the base fluid. The specific heat of the ILs-based nanofluids containing 0.03 and $0.06 \mathrm{wt} \%$ GE decreased by approximately $1.5 \%$ and $3 \%$, respectively, at each tested temperature compared with the base ILs. Similarly, Wang et al. [53] reported $0.93 \%$ reduction of specific heat at $20^{\circ} \mathrm{C}$, and $1.14 \%$ reduction at $80{ }^{\circ} \mathrm{C}$ for the $0.03 \%$ loading of $\mathrm{GE}$ in $\left[\mathrm{C}_{6} \mathrm{im}\right]\left[\mathrm{BF}_{4}\right]$ compared to the base ILs. Moreover, the authors claimed that the specific heat of the MWCNTs-dispersed ILs-based nanofluids was higher than that of the GE-dispersed IL at the same concentration, and for all considered temperature ranges as shown in Figure 7. 


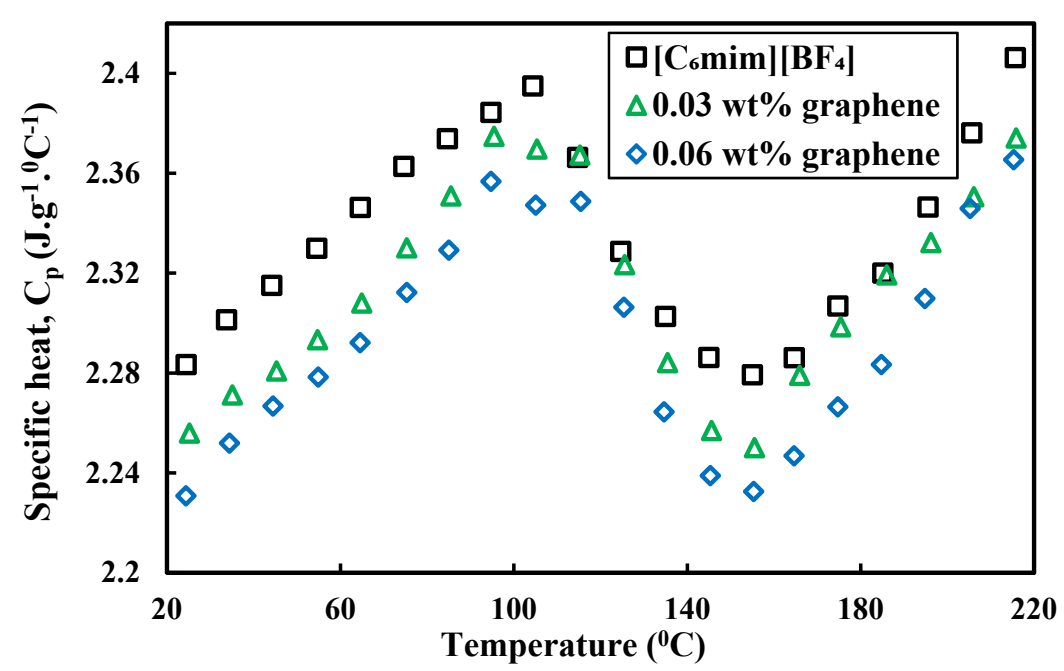

Figure 6. Specific heat of $\left[\mathrm{C}_{6} \mathrm{mim}\right]\left[\mathrm{BF}_{4}\right]$ and GE-dispersed IL [50]. Reproduced with permission from [Liu], [Renew. Energy]; published by [Elsevier], 2014.

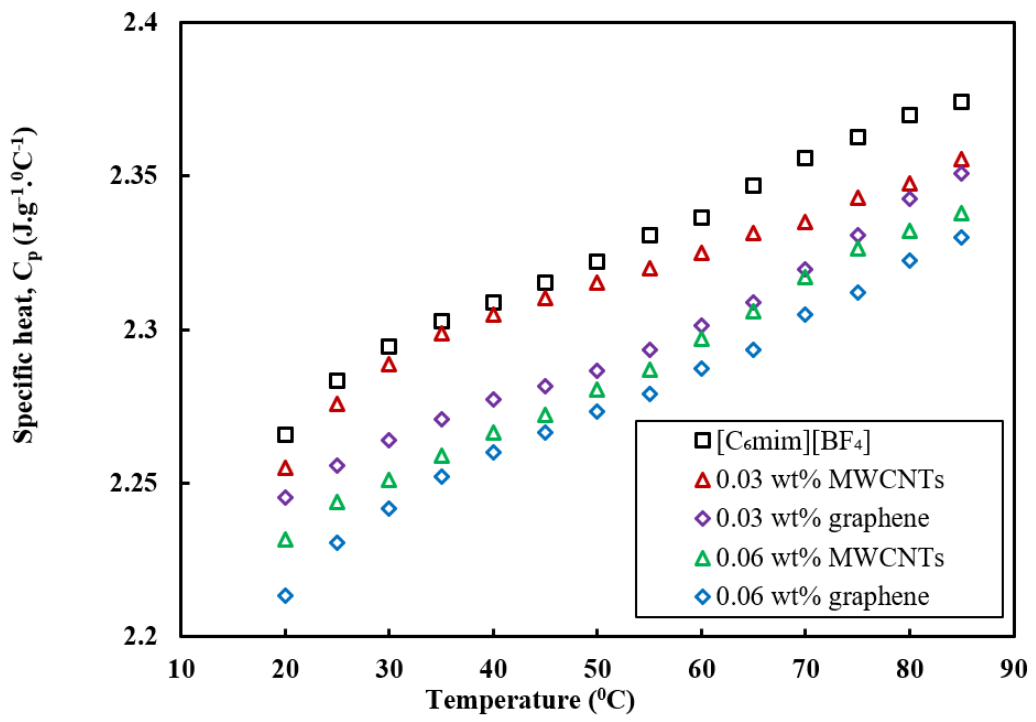

Figure 7. $\left[\mathrm{C}_{6} \mathrm{mim}\right]\left[\mathrm{BF}_{4}\right]$ and MWCNT, GE-dispersed IL [53] as a function of temperature. Reproduced with permission from F Wang, Nanoscale research letters; published by [Springer], 2012.

Recently, Chen et al. [54] experimentally studied the thermophysical properties of the $\mathrm{SiC}$ enhanced $\left[\mathrm{C}_{6} \mathrm{mim}\right]\left[\mathrm{BF}_{4}\right]$ ILs for three different concentrations of $\mathrm{SiC}$ within a temperature range of $0-80^{\circ} \mathrm{C}$. The authors reported the opposite behavior of the specific heat than the previous authors [50,53]. The results depicted an almost linear increment in specific heat, with temperature behaving independently of the weight \% of the $\mathrm{SiC}$, and it was seen that the addition of $\mathrm{SiC}$ nanoparticles enhanced the specific heat of base fluids. For example, a maximum 5\% enhancement of specific heat was observed for $0.06 \mathrm{wt} \% \mathrm{SiC}$ ionanofluids at $25{ }^{\circ} \mathrm{C}$ compared with the base fluid. This could be explained by the comparatively higher specific heat of the $\mathrm{SiC}$ nanoparticles than the usualcarbonbased additives.

Specific heat capacity of ILs-based nanofluids comprised of $\left[\mathrm{C}_{4} \mathrm{mim}\right]\left[\mathrm{PF}_{6}\right]$ and MWCTs as a function of temperature and concentration was studied by Castro et al. [55]. The author found that that the enhancement ratio of MWCNT-ionanofluids is more than 1 , from room temperature to $115^{\circ} \mathrm{C}$. Moreover, regardless of the weight \% of the MWCNTs, the enhancement ratio reached a peak value at a certain temperature range of $60-110^{\circ} \mathrm{C}$. The authors did not provide a reason to explain this unusual result. 
Paul et al. [56] studied the effects of $\mathrm{Al}_{2} \mathrm{O}_{3}$ nanoparticles on the specific heat of the $\left[\mathrm{C}_{4} \mathrm{mim}\right]\left[\mathrm{NTf}_{2}\right]$ and $\left[\mathrm{C}_{4}\right.$ mpyrr] $\left[\mathrm{NTf}_{2}\right]$ ILs. For both ILs-based nanofluids, the authors considered $1 \mathrm{wt} \%$ of nanoparticle. The results illustrated that, for both ILs-based nanofluids, the enhancement ratio was more than 1 within the experimental temperature range. In case of $\left[\mathrm{C}_{4} \mathrm{mim}\right]\left[\mathrm{NTf}_{2}\right] \mathrm{IL}$, a sharp increase in the specific heat ratio was evident (see Figure 8) at temperatures of less than $50{ }^{\circ} \mathrm{C}$. Afterwards, the enhancement ratio remains almost constant within a wide temperature range of $70-220^{\circ} \mathrm{C}$, and finally, a gradual reduction was reported at higher temperatures. However, for $\left[\mathrm{C}_{4} \mathrm{mpyrr}\right]\left[\mathrm{NTf}_{2}\right] \mathrm{IL}$, the enhancement ratio reached a peak value of 1.264 at $75{ }^{\circ} \mathrm{C}$, followed by an almost linear reduction with temperature. Moreover, from the Figure 8 , it can be seen that for almost all the temperature range, the specific heat enhancement ratio of the $\left[\mathrm{C}_{4} \mathrm{mim}\right]\left[\mathrm{NTf}_{2}\right]$ based nanofluids was higher compared to the $\left[\mathrm{C}_{4}\right.$ mpyrr] $\left[\mathrm{NTf}_{2}\right]$ based nanofluids. The authors also concluded that theoretical model always under-predicted the enhancement ratio of nanoparticleenhanced ILs. Using a group method data handling technique, Sadi [87] reported similar behavior in specific heat of ILs-based nanofluids comprised of $\mathrm{Al}_{2} \mathrm{O}_{3}$ nanoparticles and $\left[\mathrm{C}_{4} \mathrm{mim}\right]\left[\mathrm{NTf}_{2}\right]$ ILs.

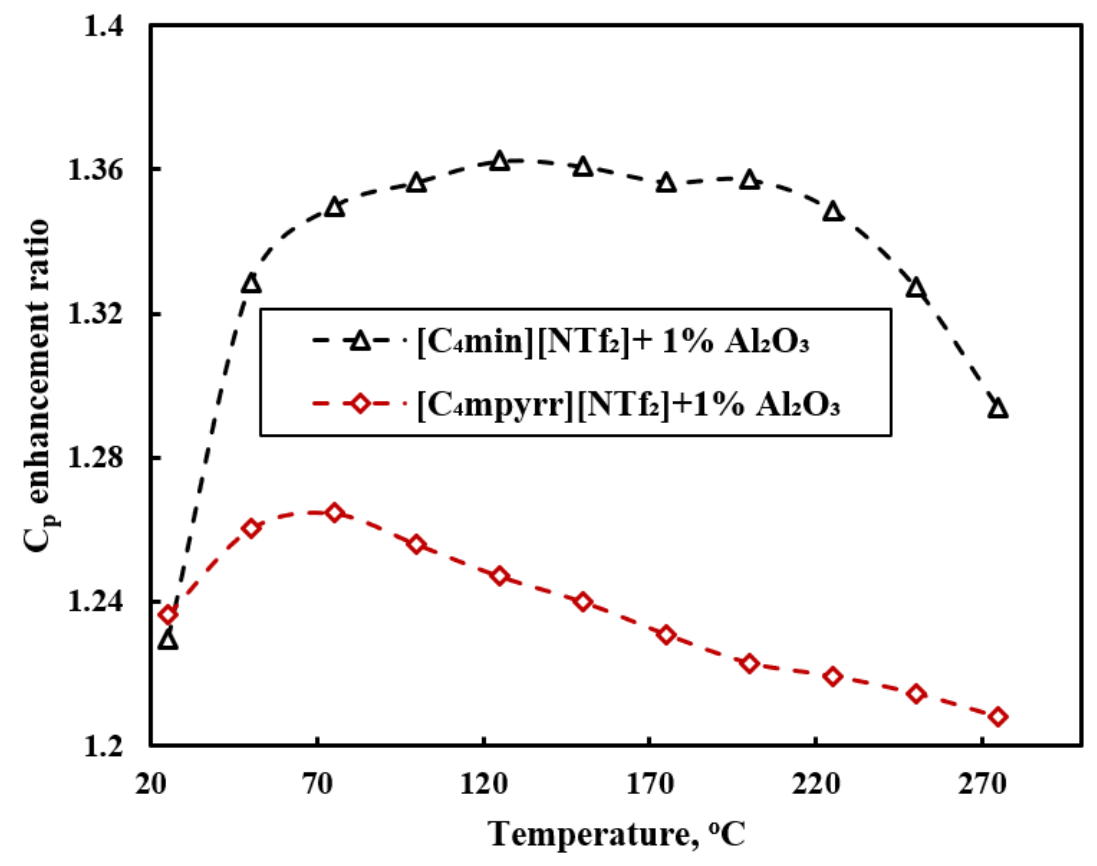

Figure 8. Heat capacity enhancement ratio of NEILs vs. temperature [56]. Reproduced with permission from [Paul], [Procedia Eng.]; published by [Elsevier], 2013.

The effects of MWCNT, boron nitride (BN), and graphite (G) nanoparticles and their concentrations on the specific heat of different ILs such as $\left[\mathrm{C}_{4} \mathrm{C}_{1} \mathrm{Im}\right][\mathrm{Dca}],\left[\mathrm{C}_{4} \mathrm{C}_{1} \mathrm{Pyrr}\right]\left[\mathrm{NTf}_{2}\right]$, and $\left[\mathrm{C}_{6} \mathrm{C}_{1} \mathrm{Im}\right]\left[\mathrm{PF}_{6}\right]$ were experimentally studied by Oster et al. [57] at a constant pressure of $0.1 \mathrm{MPa}$. Oster et al. [57] studied the heat capacity of ILs-based nanofluids with MWCNTs, boron nitride (BN), and graphite nanoparticles, and found that a maximum of $12-28 \%$ enhancement in specific heat was achieved for graphite nanoparticles, whereas a minimum of a $5-13 \%$ increment was reported for the MWCNTs. This behavior can be attributed to the size, shape, surface area of the nanoparticle, and to the generated interfacial nanolayers of nanoparticles with the ILs molecules. Moreover, the authors also concluded that the enhancement of the specific heat primarily depended on the nanoparticle itself rather than ionic liquid type.

\subsection{Thermal Conductivity}

Recently, ionic liquids and their composition with nanoparticles (ILs-based nanofluids) have attained great attention from the heat transfer community as potential HTFs, 
especially for solar energy system such as concentrating solar power (CSP). Therefore, characterization of thermal conductivity plays a crucial role to determine the viability of ILs-based nanofluids as HTFs.

The effect of surface state or the size of gold nanoparticles (Au NPs), as well as dispersion conditions on the thermal conductivity of $\left[\mathrm{C}_{4} \mathrm{mim}\right]\left[\mathrm{PF}_{6}\right]$ nanofluids, were experimentally studied by Wang et al. [58]. The authors considered a constant volume fraction $(0.00102 \mathrm{vol} . \%)$ of the nanoparticle for all sizes of the Au NPs, and for all of the temperature range $\left(33\right.$ to $\left.81^{\circ} \mathrm{C}\right)$. The author found that at low temperature $\left(33^{\circ} \mathrm{C}\right)$, the enhancement of the thermal conductivity is very minimal. However, at higher temperature $\left(43^{\circ} \mathrm{C}\right.$ and $70^{\circ} \mathrm{C}$ ), a larger enhancement in thermal conductivity was reported. Interestingly, the authors observed a peak enhancement in the thermal conductivity at $18.4 \mathrm{~nm}$. To explain this behavior, the authors considered that the phenomenon may be related to the synergistic effect of clustering and Brownian motion as a result of dispersion condition. Micro-convection caused by Brownian motion and interface thermal resistance was also considered by the authors. Moreover, at higher temperatures $\left(81^{\circ} \mathrm{C}\right)$, the enhancement ratio showed an inverse behavior with the particle size, which indicated that the micro-convection induced by Brownian motion begins to play a dominant role in the heat transport processes at higher temperature.

The effect of volumetric fractions of Au NPs along with $5 \mathrm{mM}$ of CTABr stabilizer as a function of temperature for the $\left[\mathrm{C}_{4} \mathrm{mim}\right]\left[\mathrm{PF}_{6}\right]$ ILs was also studied by the same group [59]. The author found that at low temperature $\left(<53{ }^{\circ} \mathrm{C}\right)$, the enhancement of thermal conductivity was very negligible regardless of the Au NPs concentration. On the contrary, a very sharp increment was evident at high temperatures $\left(>60^{\circ} \mathrm{C}\right)$, exhibiting a non-linear increment with temperature. A maximum of $13.1 \%$ increment in thermal conductivity was evident for a volumetric concentration of $1.02 \times 10^{-3} \% \mathrm{Au}$ NPs. This phenomenon could be attributed to reduced viscosity of the nanofluids which accelerate the Brownian motion of the Au NPs, which eventually increases the micro-convection and consequently enhances thermal transport capabilities of the ILs-based nanofluids at high temperatures and concentrations of the nanoparticle.

Fox et al. [60] investigated the effect of the shape of alumina nanoparticles as well as various carbonaceous materials, such as stacked graphene nanofiber (SGNF), MWCNTs, and SWCNTs on the thermal conductivity of the $\left[\mathrm{C}_{4} \mathrm{mmim}\right]\left[\mathrm{TNf}_{2}\right]$ ILs-based nanofluids as a function of temperature. From Figure 9, we can observe that for the base ILs, temperature had very negligible effect on the thermal conductivity, and had a constant value of $\sim 0.126 \mathrm{~W} \cdot \mathrm{m}^{-1} \cdot \mathrm{K}^{-1}$ which is $\sim 22 \%$ lower than the water. From the figure it can also be seen that only MWCNTs and both shape of the alumina nanoparticle exhibited enhancement in thermal conductivity, whereas SGNF and SWCNTs showed opposite effect. At low temperatures $\left(<30^{\circ} \mathrm{C}\right)$, MWCNTs depicted a maximum $4 \%$ increment in thermal conductivity and afterwards decreased drastically with temperature. Similar behavior was also observed in case of SWCNT. Moreover, at relatively higher temperatures $\left(>45^{\circ} \mathrm{C}\right)$, whisker $\mathrm{Al}_{2} \mathrm{O}_{3}$ nanoparticle showed significant increment in thermal conductivity of ILs-based nanofluids than MWCNTs. It is worth noting that the shape of the alumina nanomaterial has a significant effect on the thermal conductivity with temperature, but the effect is much more dramatic for the whisker-shaped nanoparticles. Although the authors did not provide the clear mechanism for enhanced thermal conductivity of ILs-based nanofluids, they did identify Brownian motion of the nanoparticles, liquid stacking at the particle/liquid interface, inherent means of heat transport within the nanoparticles, nanoparticle clustering, and particle surface chemistry as the possible reason of the specific trend of the thermal conductivity. 


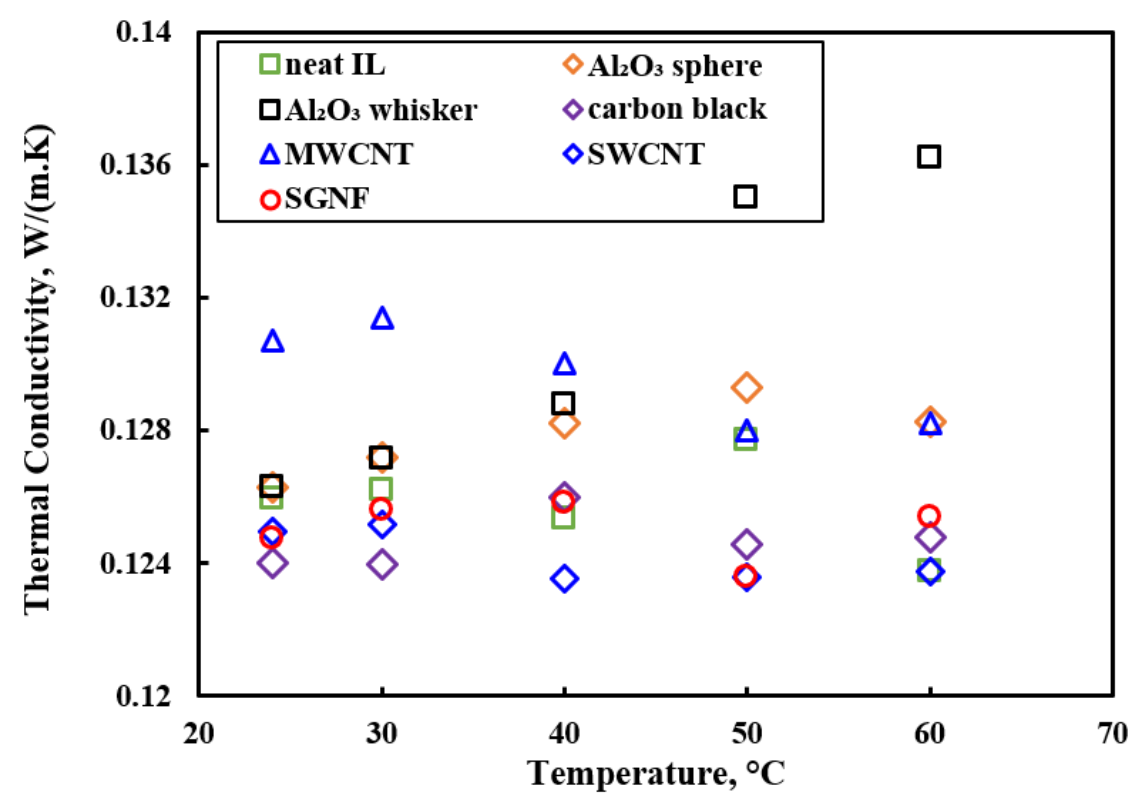

Figure 9. Effect of temperature on the thermal conductivity of different ILs-based nanofluids [60]. Reproduced with permission from [Foxr], [Energy Fuels]; published by [ACS], 2013.

Nieto de Castro et al. [61] experimentally investigated the thermal conductivity of ILs-based nanofluids prepared by dispersing $0.01 \mathrm{wt} \%$ of MWCNTs into $\left[\mathrm{C}_{6} \mathrm{mim}\right]\left[\mathrm{BF}_{4}\right],\left[\mathrm{C}_{4} \mathrm{mim}\right]\left[\mathrm{PF}_{6}\right]$, $\left[\mathrm{C}_{6} \mathrm{mim}\right]\left[\mathrm{PF}_{6}\right],\left[\mathrm{C}_{4} \mathrm{mim}\right]\left[\mathrm{CF}_{3} \mathrm{SO}_{3}\right]$, and $\left[\mathrm{C}_{4} \mathrm{mpyrr}\right]\left[\left(\mathrm{CF}_{3} \mathrm{SO}_{2}\right)_{2} \mathrm{~N}\right]$ ILs for a wide range of temperatures $\left(20-80^{\circ} \mathrm{C}\right)$ and at a constant pressure of $0.1 \mathrm{MPa}$. From Figure 10, it can be seen that most of the ILs-based nanofluids exhibited negligible dependency on temperature variation. For example, a $\sim 3.4 \%, 1.8 \%$, and $5 \%$ increment in thermal conductivity was reported for $\left[\mathrm{C}_{4} \mathrm{mim}\right]\left[\mathrm{PF}_{6}\right]$, $\left[\mathrm{C}_{6} \mathrm{mim}\right]\left[\mathrm{PF}_{6}\right]$, and $\left[\mathrm{C}_{4} \mathrm{mpyrr}\right]\left[\left(\mathrm{CF}_{3} \mathrm{SO}_{2}\right)_{2} \mathrm{~N}\right] \mathrm{ILs}$, respectively, for the whole temperature range. However, nanofluids based on $\left[\mathrm{C}_{6} \mathrm{mim}\right]\left[\mathrm{BF}_{4}\right]$ and $\left[\mathrm{C}_{4} \mathrm{mim}\right]-\left[\mathrm{CF}_{3} \mathrm{SO}_{3}\right]$ showed a temperature dependent enhancement in thermal conductivity, and a maximum increment of $\sim 9 \%$ and $7 \%$ were claimed by the authors at a temperature of $80^{\circ} \mathrm{C}$. From the figure, it can also be seen that nanofluids containing [PF6]-based ILs have the smallest enhancement in thermal conductivity, while nanofluids based on $\left[\mathrm{C}_{6} \mathrm{mim}\right]\left[\mathrm{BF}_{4}\right]$ have the largest enhancement. The authors claimed that the particle surface chemistry and the structure of the interphase nanoparticle/fluid were responsible for the enhancement in thermal conductivity of the ILs-based nanofluids.

Figure 11 depicts the effect of concentration of the GE and MWCNTs nanoparticle on the thermal conductivity of $\left[\mathrm{C}_{6} \mathrm{mim}\right]\left[\mathrm{BF}_{4}\right]$ ILs as a function of temperature, as studied by Wang et al. [53]. Linear increment in thermal conductivity with temperature of both base ILs and their nanofluids was evident. From the figure, it can also be seen that for both ILs-based nanofluids, thermal conductivity increased with the mass fraction of the nanoparticle at any specific temperature. This is because of the higher thermal conductivity of the nanoparticles compared to the base fluid. The authors also revealed that at the same concentration of nanoparticles, the thermal conductivity of the GE-dispersed IL was higher than the thermal conductivity of the MWCNTs-dispersed IL. This could be attributed to the extraordinary high thermal conductivity of GE and Brownian motion of nanoparticles at the molecular and nanoscale levels. The reported maximum increment in thermal conductivity of GE and MWCNT based ILs were $18.6 \%$ and $13.2 \%$, respectively. 


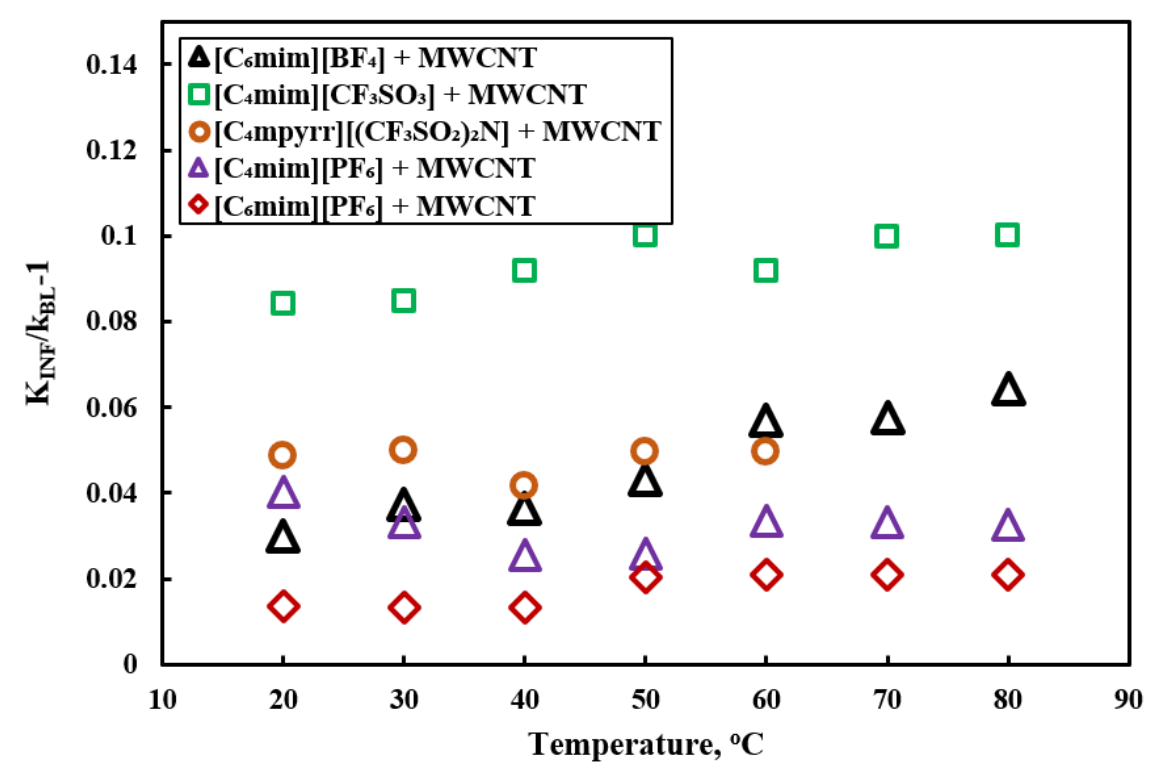

Figure 10. Comparison between MWCNTs-dispersed ILs as a function of temperature [61]. Reproduced with permission from [Nieto de Castro], [J. Chem. Eng. Data]; published by [ACS], 2010.

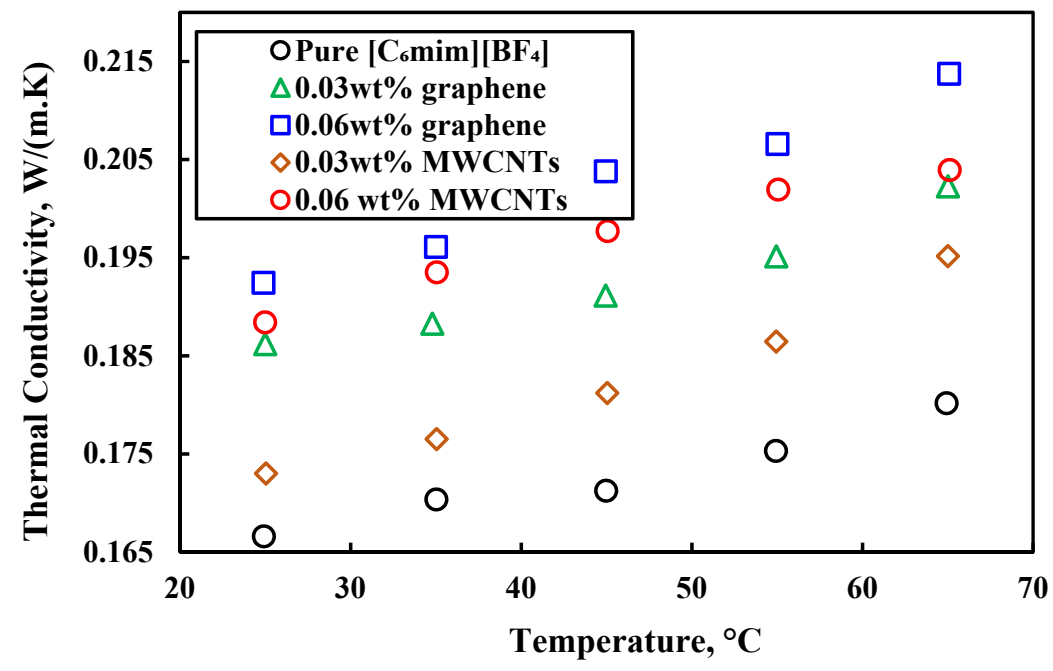

Figure 11. Effect of Graphene and MWCNT concentration on the thermal conductivity of $\left[\mathrm{C}_{6} \mathrm{mim}\right]\left[\mathrm{BF}_{4}\right]$ IL [53]. Reproduced with permission from F Wang, Nanoscale research letters; published by [Springer], 2012.

Thermal conductivity of four different ILs-based nanofluids, comprised of $\left[\mathrm{C}_{4} \mathrm{mim}\right]\left[\mathrm{NTf}_{2}\right]$, $\left[\mathrm{C}_{4} \mathrm{mmim}\right]\left[\mathrm{NTf}_{2}\right],\left[\mathrm{C}_{4}\right.$ mpyrr] $\left[\mathrm{NTf}_{2}\right]$, and $\left[\mathrm{N}_{4111}\right]\left[\mathrm{NTf}_{2}\right]$ ILs and $\mathrm{Al}_{2} \mathrm{O}_{3}$ nanoparticles as a function of dispersion concentration, were experimentally studied by Paul et al. [62]. The authors considered three different weight percentages of the nanoparticles $(0.5,1.0$, and $2.5 \%)$ and conducted experiments for a wide range of temperatures. Figure 12 depicts the enhancement of thermal conductivity for ILs-based nanofluids as a function of temperature. The authors reported a maximum $9 \%$ increment in the thermal conductivity for $\left[\mathrm{C}_{4} \mathrm{mmim}\right]\left[\mathrm{NTf} \mathrm{f}_{2}\right]$, as well as for the highest concentration of the $\mathrm{Al}_{2} \mathrm{O}_{3}$ nanoparticle along with a weak temperature dependency. They predicted possible mechanisms of thermal conductivity and enhancement of traditional nanofluids to be the Brownian motion of nanoparticles, the nature of heat transport to the nanoparticles [88], interfacial layer thickness [76,89], and the effect of nanoparticle clustering [90]. The same group studied the effect of the shape (spherical and whiskers) of $\mathrm{Al}_{2} \mathrm{O}_{3}$ nanoparticle dispersed in $\left[\mathrm{C}_{4} \mathrm{mpyrr}\right]\left[\mathrm{NTf}_{2}\right]$ ILs as a function of concentration and temperature [84]. Regardless of the concentration and temperature, higher thermal conduc- 
tivity was observed for whiskers nanoparticles when compared to spherical. For example, a maximum $\sim 11 \%$ and $\sim 14 \%$ enhancement in thermal conductivity was observed for $2.5 \mathrm{wt} \%$ of spherical and whiskers ILs-based nanofluids, respectively, at $70{ }^{\circ} \mathrm{C}$. The authors identified the higher aspect ratio of the whiskers shaped nanoparticle compared to the spherical shaped nanoparticles as a plausible reason along with other thermal conductivity enhancement mechanism as stated earlier.

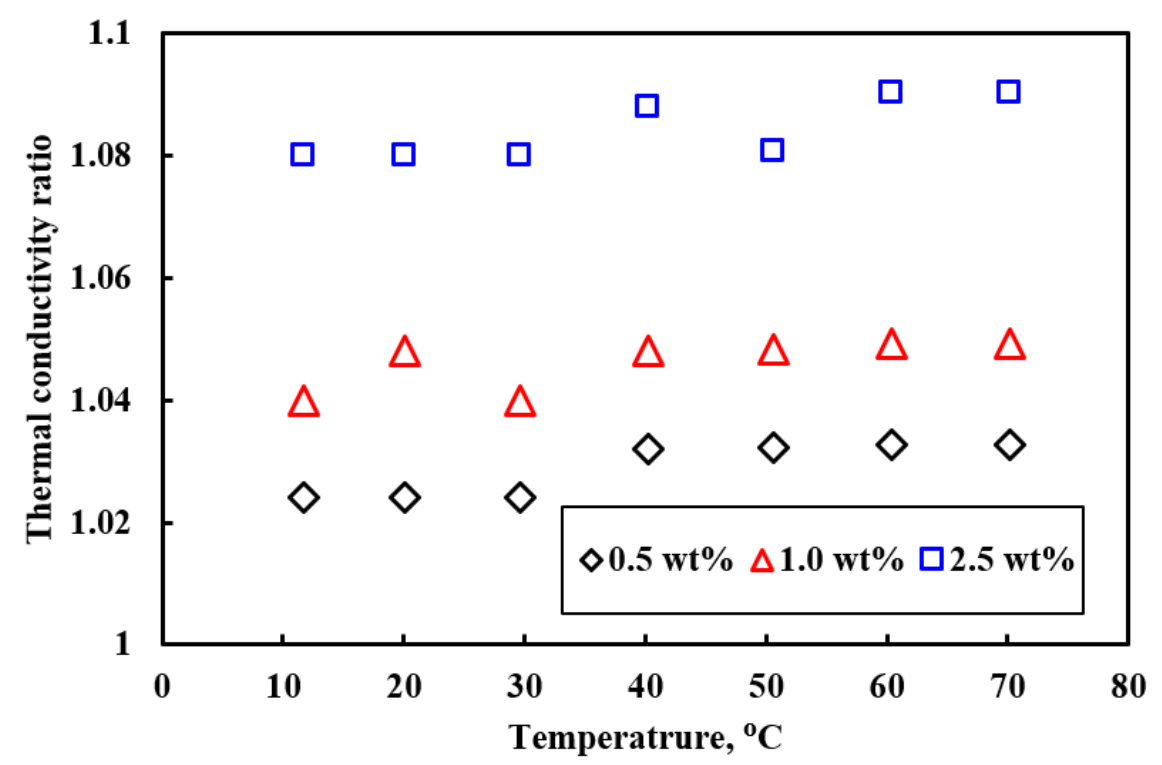

Figure 12. Thermal conductivity ratio of $\mathrm{Al}_{2} \mathrm{O}_{3}$ nanoparticles enhanced[C $\mathrm{C}_{4}$ mmim][NTf $\left.\mathrm{N}_{2}\right]$ IL[62]. Reproduced with permission from [Paul], [. Appl. Therm. Eng.]; published by [Elsevier], 2017.

Franca et al. [63] reported the thermal conductivity behavior of four different nanofluids based on $\left[\mathrm{C}_{2} \mathrm{mim}\right][\mathrm{SCN}],\left[\mathrm{C}_{4} \mathrm{mim}\right][\mathrm{SCN}],\left[\mathrm{C}_{2} \mathrm{mim}\right]\left[\mathrm{C}(\mathrm{CN})_{3}\right]$, and $\left[\mathrm{C}_{4} \mathrm{mim}\right]\left[\mathrm{C}(\mathrm{CN})_{3}\right]$, with 0.5 and $1 \%$ mass fraction of MWCNTs and compared the results with the base fluid at pressure $0.1 \mathrm{MPa}$ and in the temperature range of $20-70^{\circ} \mathrm{C}$. From Figures 13 and 14, it can be seen that at higher temperatures, the thermal conductivity of $\mathrm{C}_{2} \mathrm{mim}^{+}$ionanofluids is higher than the thermal conductivity of $\mathrm{C}_{4} \mathrm{mim}^{+}$ionanofluids regardless of the concentration. Proportional enhancement in thermal conductivity was evident for $\left[\mathrm{C}_{2} \mathrm{mim}\right][\mathrm{SCN}]$, and $\left[\mathrm{C}_{4} \mathrm{mim}\right][\mathrm{SCN}]$ ionanofluids (see Figure 13) while non-linear increment in thermal conductivity was reported with temperature. The authors reported a maximum 32.3 and $18.7 \%$ increment in thermal conductivity for $1 \mathrm{w} / \mathrm{w} \%$ of MWCNTs-enhanced $\left[\mathrm{C}_{2} \mathrm{mim}\right][\mathrm{SCN}]$, and $\left[\mathrm{C}_{4} \mathrm{mim}\right][\mathrm{SCN}] \mathrm{ILs}$, respectively. Similar behavior was evident for $\left[\mathrm{C}_{2} \mathrm{mim}\right]\left[\mathrm{C}(\mathrm{CN})_{3}\right]$, and $\left[\mathrm{C}_{4} \mathrm{mim}\right]\left[\mathrm{C}(\mathrm{CN})_{3}\right]$ ionanofluids, respectively, within a temperature range of $20-57^{\circ} \mathrm{C}$. However, at higher temperatures $\left(>57^{\circ} \mathrm{C}\right)$, the enhancement in thermal conductivity exhibited a negative slope.

To increase the dispersion stability of the GE nanoparticle in $\left[\mathrm{C}_{6} \mathrm{mim}\right]\left[\mathrm{BF}_{4}\right] \mathrm{IL}$, Liu et al. [64] modified the $\mathrm{GE}$ nanoparticle using $\mathrm{SOCl}_{2}$ reagent and studied the thermophysical properties of the modified GE (MGE) and $\left[\mathrm{C}_{6} \mathrm{mim}\right]\left[\mathrm{BF}_{4}\right]$ mixtures for a wide range of temperatures $\left(20-145^{\circ} \mathrm{C}\right)$. The authors considered three different concentrations of MGE, 0.01, 0.03, and $0.05 \mathrm{wt} \%$, and compared their thermal conductivity with pure $\left[\mathrm{C}_{6} \mathrm{mim}\right]\left[\mathrm{BF}_{4}\right]$ and $0.01 \mathrm{wt} \%$ of $\mathrm{GE} /\left[\mathrm{C}_{6} \mathrm{mim}\right]\left[\mathrm{BF}_{4}\right]$ mixture. In the case of $\mathrm{MGE} /\left[\mathrm{C}_{6} \mathrm{mim}\right]\left[\mathrm{BF}_{4}\right]$ mixture, a significant increment in thermal conductivity was evident within the whole temperature range. For example, in case of 0.01 and $0.05 \mathrm{wt} \%$ dispersion of $\mathrm{MGE}$, the thermal conductivity of $\left[\mathrm{C}_{6} \mathrm{mim}\right]\left[\mathrm{BF}_{4}\right]$ increased by $\sim 5$ and $10 \%$, respectively. However, for the $0.01 \% \mathrm{GE} /\left[\mathrm{C}_{6} \mathrm{mim}\right]\left[\mathrm{BF}_{4}\right]$ mixture, the thermal conductivity increased by $6.2 \%$ which was slightly higher than the thermal conductivity enhanced using $0.01 \mathrm{wt} \%$ of MGE. This is because of the grafting of the molecular chain on the surfaces of the nanosheets. 


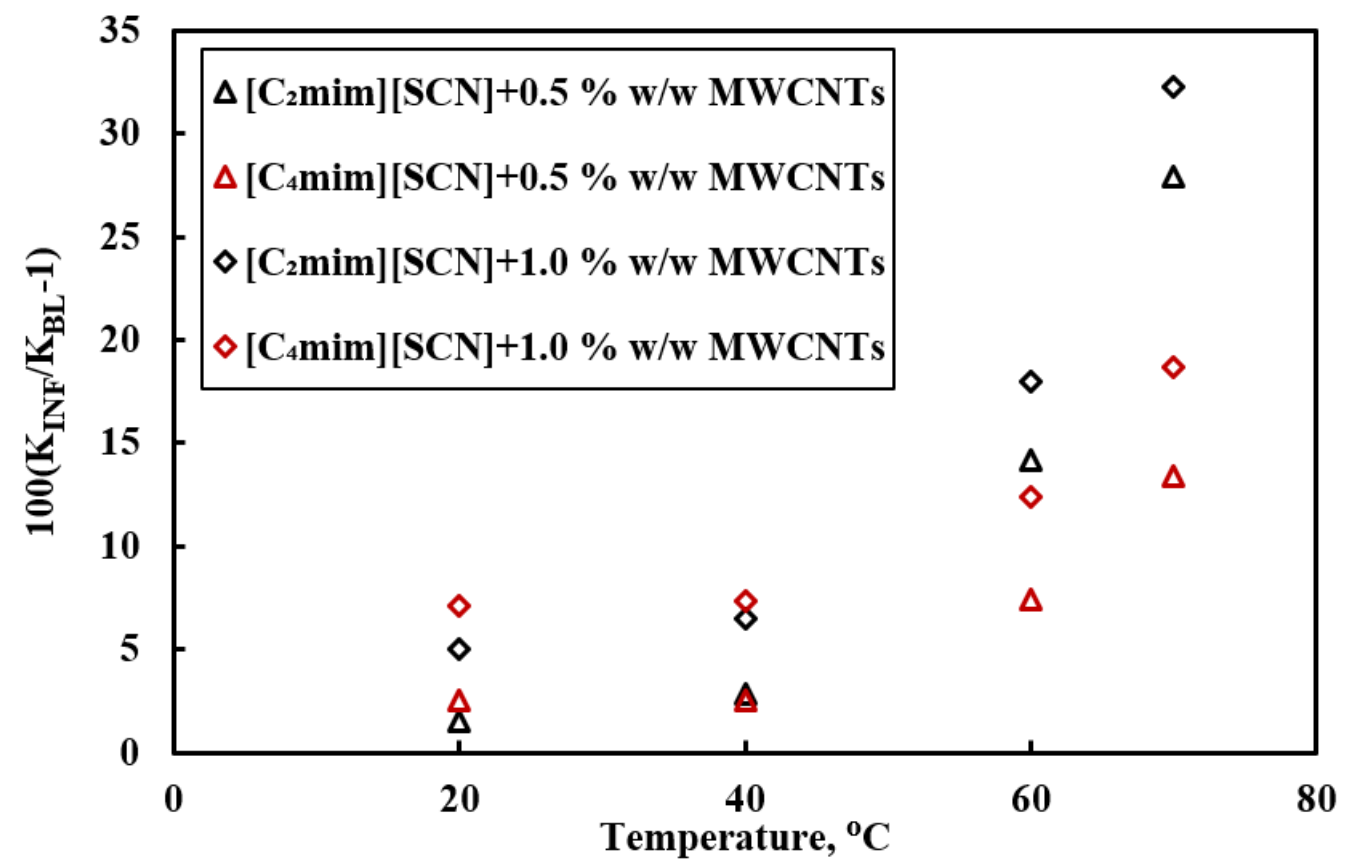

Figure 13. Enhancement ratio of the thermal conductivity of MWCNTs-enhanced ILs as a function of nanoparticle concentration and temperature with [SCN] anion [63]. Reproduced with permission from [França], [Ind. Eng. Chem. Res.]; published by [ACS], 2018.

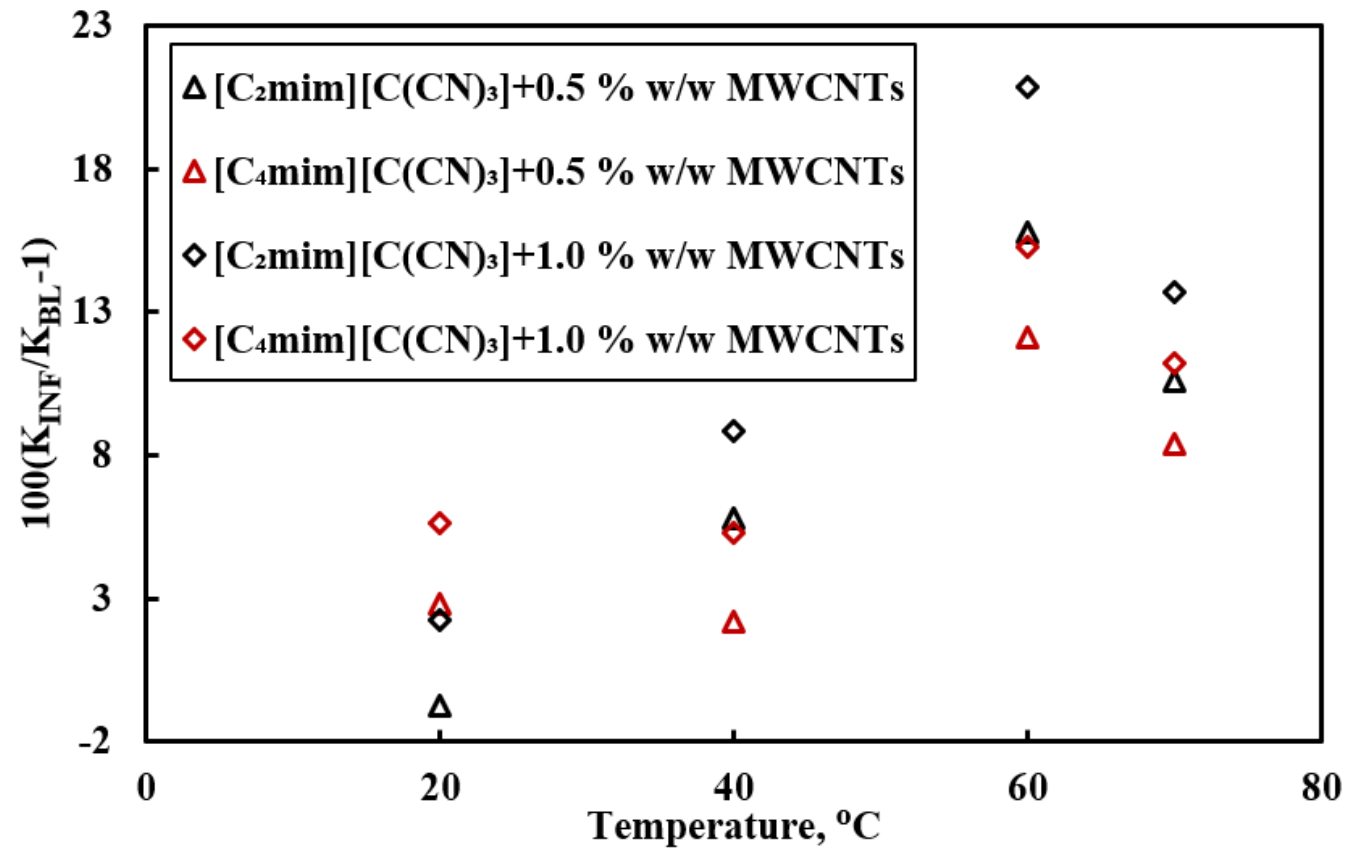

Figure 14. Enhancement ratio of the thermal conductivity of MWCNTs-enhanced ILs as a function of nanoparticle concentration and temperature with $\mathrm{C}(\mathrm{CN})_{3}$ anion [63]. Reproduced with permission from [França], [Ind. Eng. Chem. Res.]; published by [ACS], 2018.

The effects of functionalized multi-wall carbon nanotube (F-MWCNTs) and pristine multi-wall carbon nanotube (P-MWCNTs) along with CATB on the thermal conductivity of $\left[\mathrm{C}_{4} \mathrm{mim}\right]\left[\mathrm{PF}_{6}\right]$ IL were studied by Wang et al. [65] as a function of concentration and for a temperature range of $25-45{ }^{\circ} \mathrm{C}$. At low temperatures $\left(25\right.$ and $\left.35{ }^{\circ} \mathrm{C}\right)$, F-MWCNTs $/\left[\mathrm{C}_{4} \mathrm{mim}\right]\left[\mathrm{PF}_{6}\right]$ ionanofluid showed a constant value $(\sim 1)$ of the thermal conductivity ratio, regardless of the concentration of the nanoparticle, since base liquid dom- 
inates the thermal conduction of the ionanofluid at low temperatures. It was also seen that at $35^{\circ} \mathrm{C}$, the thermal conductivity ratio was less than $25^{\circ} \mathrm{C}$, because of the tiny microstructure variation of MWCNTs. Moreover, at $45^{\circ} \mathrm{C}$ and $50{ }^{\circ} \mathrm{C}$, the thermal conductivity ratio reached a peak value at a concentration of $\sim 0.1 \mathrm{wt} \%$ which could be attributed to the topologically connected network of F-MWCNTs. The authors referred this concentration as percolation concentration. However, after the percolation concentration, aggregation of the F-MWCNTs reduced the conductivity ratio. In case of P-MWCNTs, the ratio of thermal conductivity showed a similar trend as F-MWCNTs at lower concentrations $(0.2 \mathrm{wt} \%)$, except highest enhancement in thermal conductivity, was achieved at $45{ }^{\circ} \mathrm{C}$ instead of $50{ }^{\circ} \mathrm{C}$. It is worth mentioning that after a concentration of $0.2 \mathrm{wt} \%$, thermal conductivity ratio increased almost linearly with the increase of concentration of P-MWCNTs.

\subsection{Viscosity}

Since high viscous fluids require high pumping power, in the case of choosing an appropriate HTF, viscosity plays a detrimental role. To date, numerous experimental and numerical studies have been performed to characterize the viscosity of different ILs and ILs-based nanofluids. For example, Chen et al. [54] studied the viscous properties of pure $\left[\mathrm{C}_{6} \mathrm{mim}\right]\left[\mathrm{BF}_{4}\right]$ and $\mathrm{SiC}$ dispersed ILs as a function $\mathrm{SiC}$ nanoparticles concentration within a temperature range of $25-65^{\circ} \mathrm{C}$. From Figure 15 , it can be clearly observed that the viscosity of ILs and all considered ILs-based nanofluids decreases non-linearly as temperature increases. Previous studies also demonstrated the similar behavior of viscosity with temperature [91,92]. Moreover, the viscosity of ILs-based nanofluids increased with the $\mathrm{SiC}$ loading for the whole temperature range, which can be attributed to the nanoparticles' aggregation. For example, in the case of $0.06 \mathrm{wt} \%$ of $\mathrm{SiC}$ loaded $\mathrm{IL}$, the viscosity increased by nearly $15.6 \%$ at $25{ }^{\circ} \mathrm{C}$. A similar effect of nanoparticles loading on viscosity of ILs was also reported by Saidur et al. and Zyla et al. $[93,94]$.

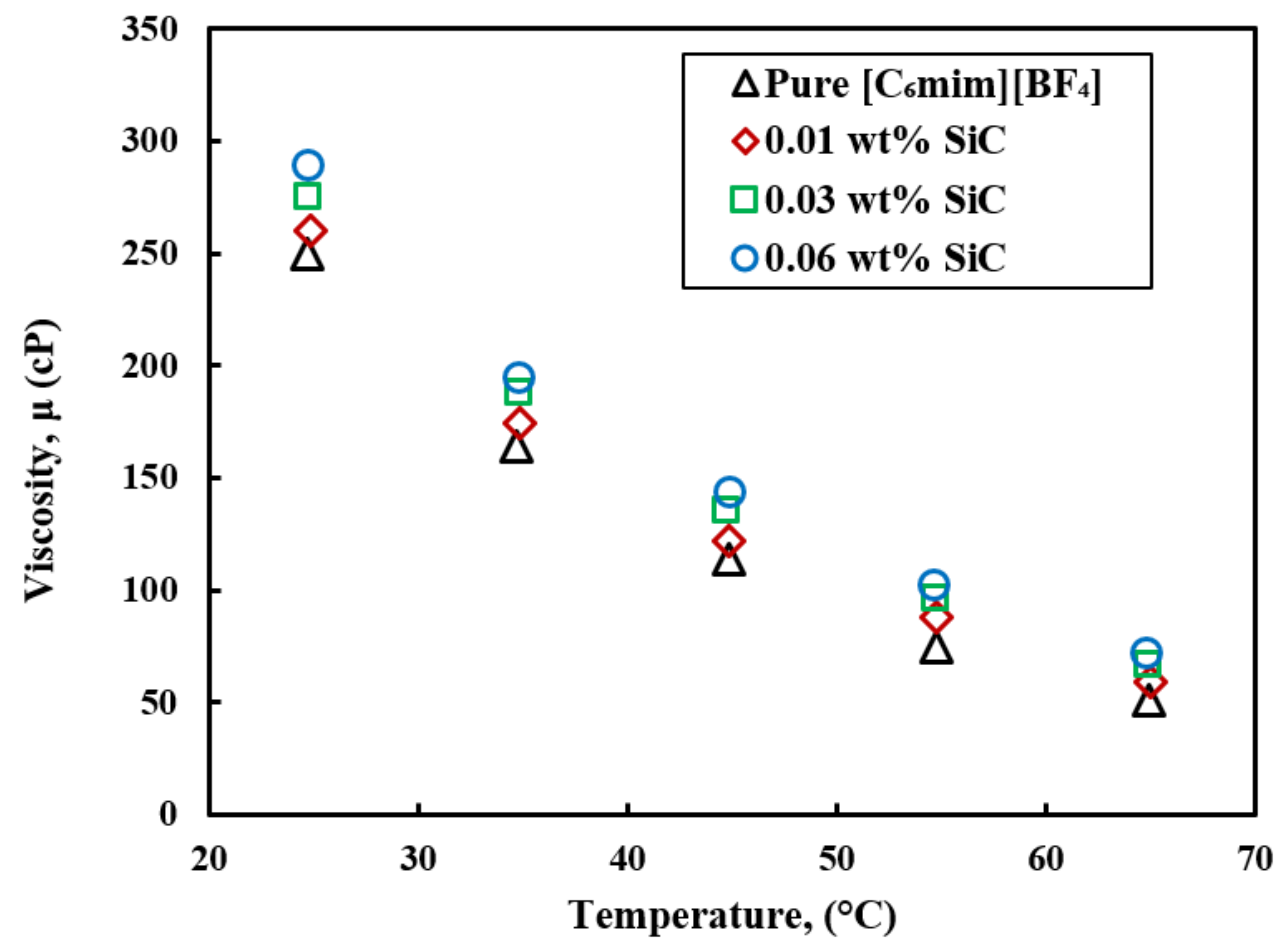

Figure 15. Viscosity of ILs-based nanofluids ( $\mathrm{SiC}$ nanoparticles) as a function of temperature [54]. Reproduced with permission from [Chen], [. Sol. Energy Mater. Sol. Cells]; published by [Elsevier], 2017.

A detailed analysis of the viscous properties of nanoparticle-enhanced $\left[\mathrm{C}_{4} \mathrm{mmim}\right]\left[\mathrm{NTf}_{2}\right]$ IL was performed by Fox et al. [60]. The authors considered ten different nanoparticles, $\mathrm{SiO}_{2}$, 
whiskers $\mathrm{Al}_{2} \mathrm{O}_{3}$, spherical $\mathrm{Al}_{2} \mathrm{O}_{3}, \mathrm{Au}, \mathrm{ZnO}, \mathrm{CuO}, \mathrm{Fe}_{2} \mathrm{O}_{3}$, SGNF, MWCNTs, and carbob back (CB), and compared their relative effects on the viscosity of the base ILs at $25^{\circ} \mathrm{C}$ and at $0.5 \mathrm{wt} \%$, loading of all nanoparticles. Negligible increment $(<6 \%)$ in viscosity was recorded for all considered nanoparticles, except for MWCNTs and CB. A maximum $\sim 10.44 \%$ increment in viscosity was recorded for MWCNTs-enhanced ILs, whereas for CB, viscosity increased by $\sim 50.6 \%$ compared to pure IL. The authors identified a high pore volume and surface area of $\mathrm{CB}$ nanoparticles as a possible reason for the viscosity's increment. The effect of the loading $\%$ of the spherical $\mathrm{Al}_{2} \mathrm{O}_{3}$ nanoparticle was also studied by the same group for a wide range of temperatures $\left(25-300{ }^{\circ} \mathrm{C}\right)$. A negligible effect, $0.5 \%$ loading of the nanoparticle, is evident for all considered temperature ranges. Conversely, in the case of $2.5 \%$ loading of the $\mathrm{Al}_{2} \mathrm{O}_{3}$, a significant increment in viscosity was recorded at lower temperatures (see Figure 16). For example, at $2.5 \mathrm{wt} \%$ of the $\mathrm{Al}_{2} \mathrm{O}_{3}$ nanoparticle, a $\sim 40 \%$ increment in viscosity is evident compared to $0.5 \mathrm{wt} \%$ and pure IL at $25^{\circ} \mathrm{C}$. Interestingly at higher temperatures $\left(300{ }^{\circ} \mathrm{C}\right)$, the nanoparticle-enhanced IL showed almost the same viscosity as pure IL regardless of the nanoparticle concentration.

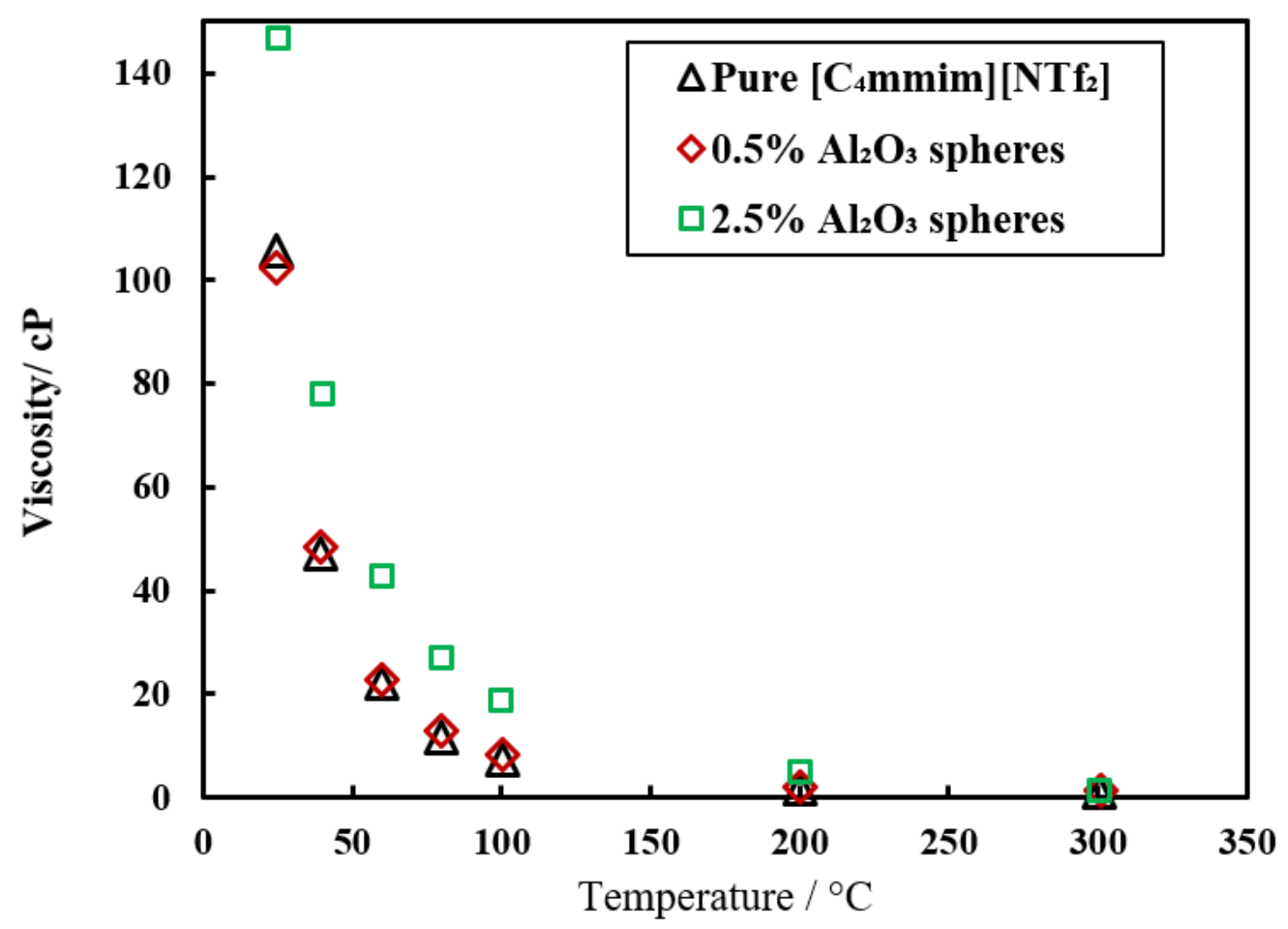

Figure 16. Effect of the spherical $\mathrm{Al}_{2} \mathrm{O}_{3}$ nanoparticle on $\left[\mathrm{C}_{4}\right.$ mmim] $\left[\mathrm{NTf}_{2}\right]$ IL viscosity as a function of temperature [60]. Reproduced with permission from [Foxr], [Energy Fuels]; published by [ACS], 2013.

Wang et al. [53] experimentally studied the viscosity of GE and $\mathrm{MWCNT}_{\mathrm{S}}$-dispersed $\left[\mathrm{C}_{6} \mathrm{mim}\right]\left[\mathrm{BF}_{4}\right] \mathrm{IL}$ as a function of nanoparticle concentration and temperature. From Figure 17, it can be seen that for all considered ionanofluids, viscosity reduces dramatically as temperature increases. The authors also reported significant reduction of viscosity of GE and MWCNTs in dispersed ionanofluids, especially at low temperature. In the case of $0.03 \mathrm{wt} \%$ of MWCNTs and at $25{ }^{\circ} \mathrm{C}$, viscosity reduced by $\sim 23 \%$ compared to the $\left[\mathrm{C}_{6} \mathrm{mim}\right]\left[\mathrm{BF}_{4}\right]$, whereas $\sim 12 \%$ reduction in viscosity is evident for $0.03 \mathrm{wt} \%$ of GE at same temperature. This behavior of viscosity could be attributed to the self-lubrication of GE and MWCNTs. On the contrary, at high temperature, all ionanofluids showed almost same viscosity as pure $\left[\mathrm{C}_{6} \mathrm{mim}\right]\left[\mathrm{BF}_{4}\right]$ regardless of the nanoparticle types and concentration. Unfortunately, the authors could not identify the mechanism of the viscosity at high temperatures but their findings were also similar to Fox et al. [60]. 


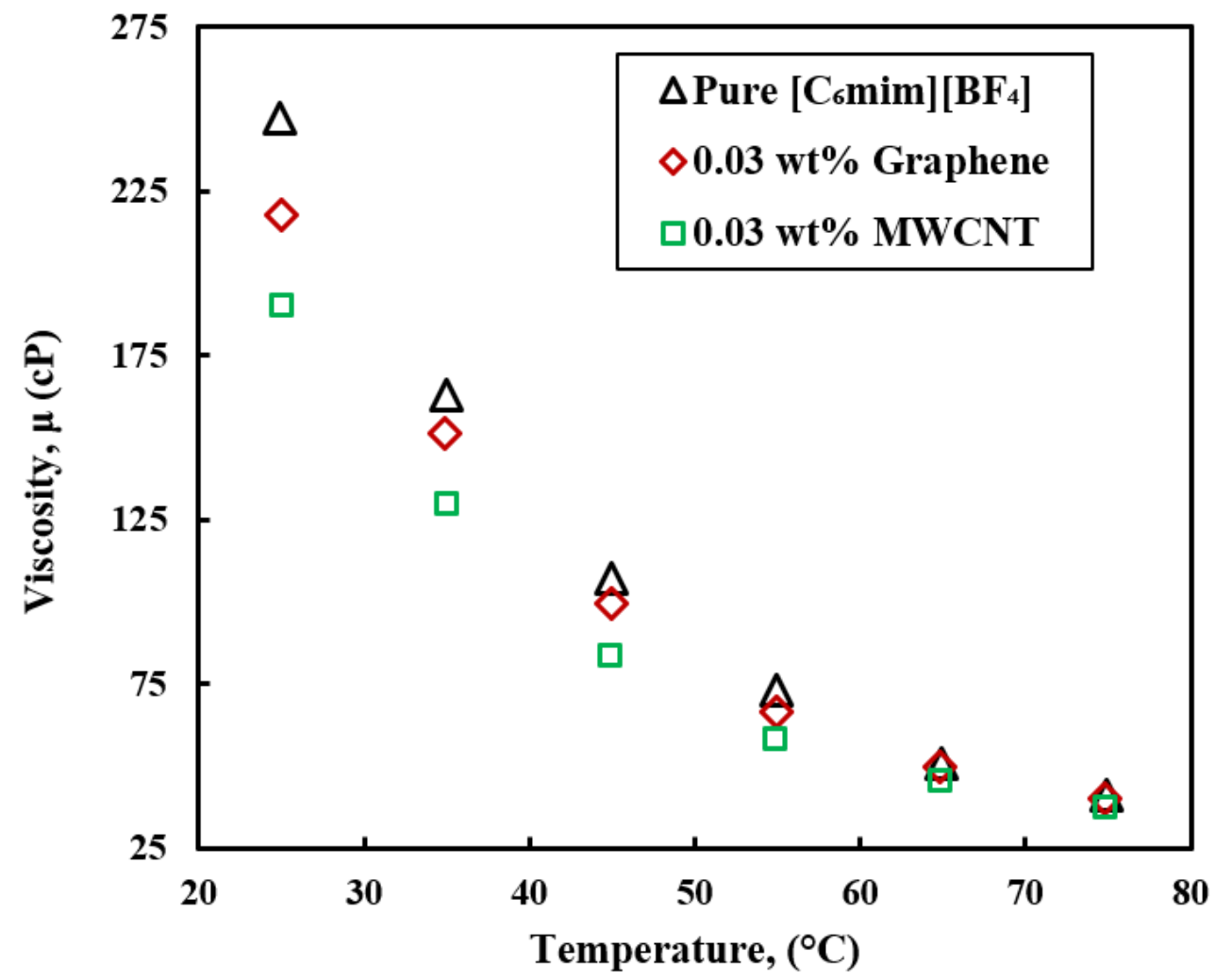

Figure 17. Effect of GE and MWCNTs nanoparticle on the viscosity of $\left[\mathrm{C}_{6} \mathrm{mim}\right]\left[\mathrm{BF}_{4}\right]$ as a function of temperature[53]. Reproduced with permission from F Wang, Nanoscale research letters; published by [Springer], 2012.

Non-Newtonian shear thinning effect of $\left.\left[\left(\mathrm{C}_{6}\right)_{3} \mathrm{PC}_{14}\right)\right][\mathrm{Phosph}]$ and $\left.\left[\left(\mathrm{C}_{6}\right)_{3} \mathrm{PC}_{14}\right)\right]\left[\mathrm{NTf}_{2}\right]$ as a function of temperature and shear rate were reported by Ferreira et al. [66]. The authors attributed this to the breaking and disruption of the nanoparticle aggregation as a possible reason of the shear thinning effect at higher shear rates. Since intermolecular interactions including $\mathrm{H}$-bonding, dispersive and coulombic interactions reduces at elevated temperatures, shear thinning effects shifted to lower shear rates. Moreover, viscosity of the $\left.\left[\left(\mathrm{C}_{6}\right)_{3} \mathrm{PC}_{14}\right)\right][\mathrm{Phosph}] \mathrm{IL}$ was decreased by $\sim 82 \%$ by adding only $0.1 \mathrm{wt} \%$ of MWCNT at room temperature. On the contrary, in the case of $\left.\left[\left(\mathrm{C}_{6}\right)_{3} \mathrm{PC}_{14}\right)\right]\left[\mathrm{NTf}_{2}\right] \mathrm{IL}$, the viscosity reduction was much smaller when compared to $\left.\left[\left(\mathrm{C}_{6}\right)_{3} \mathrm{PC}_{14}\right)\right][\mathrm{Phosph}]$. This could be attributed to the strong interaction between phosphinate anion and the CNTs surface. Similar conclusions were also drawn by Wang et al. [95] for $\left[\mathrm{C}_{12} \mathrm{C}_{12} \mathrm{im}\right] \mathrm{ILs}$.

The rheological behavior and shear viscosity of F-MWCNTs-enhanced $\left[\mathrm{C}_{4} \mathrm{mim}\right]\left[\mathrm{PF}_{6}\right]$ ILs was studied by Wang et al. [67] at different nanoparticle concentrations. At low concentrations of F-MWCNTs $(\leq 0.04 \mathrm{wt} \%)$, shear thinning effect was evident at a lower shear rate $\left(\leq 1 \mathrm{~s}^{-1}\right)$ while ionanofluids exhibited the behavior of Newtonian liquids at a high shear rate. A similar shear thinning effect was also reported by Neo et al. [68] for F-MWCNT enhanced PMII ionic liquids. However, at higher loading concentration of F-MWCNTs $(\sim 0.06-0.1 \mathrm{wt} \%)$, an enhanced shear thinning effect was evident in a wide shear rate range compared to lower concentrations of nanoparticles. This can be attributed to the transient network which was formed through nanotube-nanotube and nanotubematrix interactions at higher concentrations. The shear thinning behavior also reported by Paul et al. [49] where viscosity decreases with the shear rate and shear thinning behavior, is more significant for higher concentrations of nanoparticles (see Figure 18). 


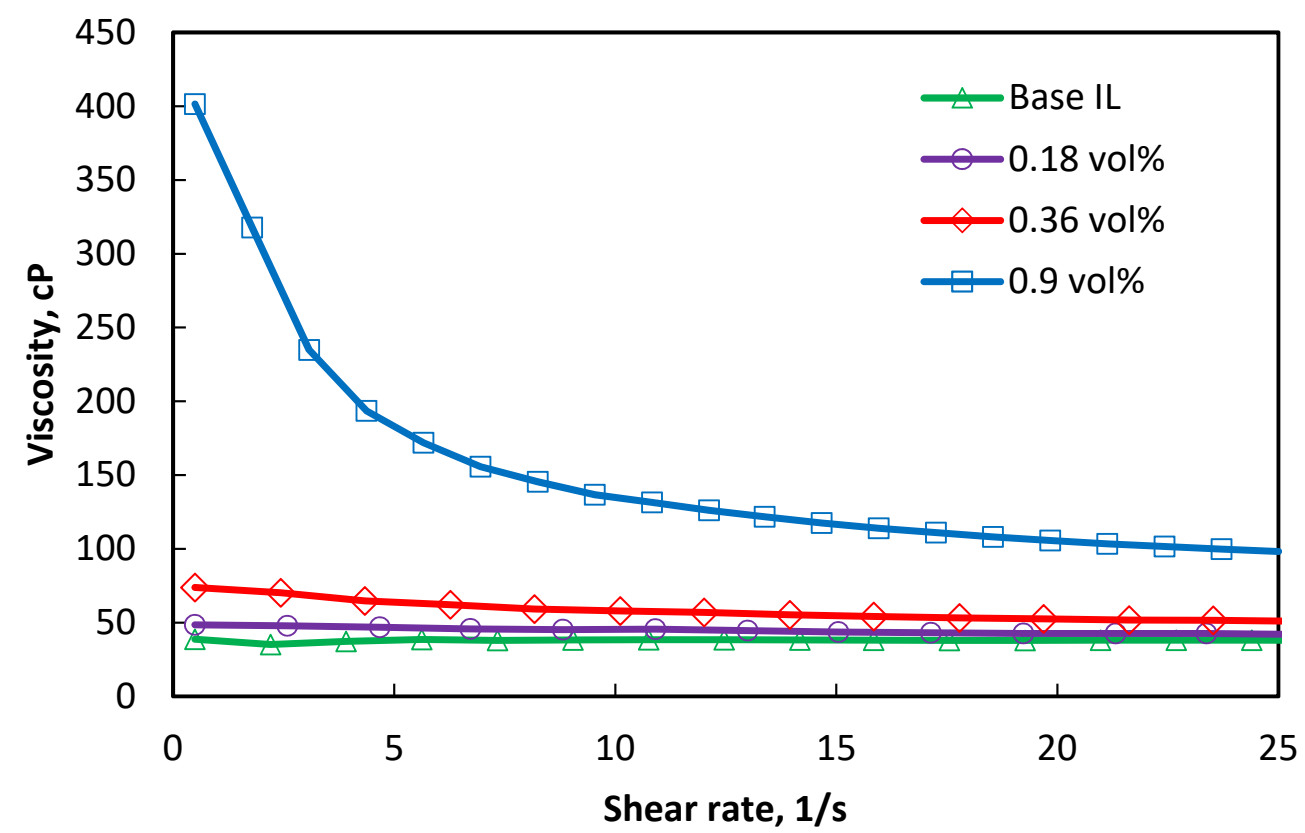

Figure 18. Rheological behavior of $\left[\mathrm{C}_{4}\right.$ mim] $\left[\mathrm{NTf}_{2}\right]$ ILs and $\mathrm{Al}_{2} \mathrm{O}_{3}$ nanoparticles enhanced nanofluids at $25^{\circ} \mathrm{C}$ [49]. Reproduced with permission from [Paul], [Int. J. Heat Mass Transf.]; published by [Elsevier], 2015.

Paul et al. [84] experimentally studied the effect of temperature, concentration, and shape of $\mathrm{Al}_{2} \mathrm{O}_{3}$ nanoparticles on the shear viscosity of $\left[\mathrm{C}_{4}\right.$ mpyrr] $\left[\mathrm{NTf}_{2}\right]$ ILs. The authors considered two different shapes for the nanoparticles, spherical and whiskers. From Figure 19a,b, it can be observed that the shear viscosity of ionanofluids increased significantly compared to base IL at room temperature, and this tendency increased with the concentration of the nanoparticles. Following this, the viscosity of all considered ionanofluids reduced non-linearly with temperature, and at elevated temperatures $\left(>77^{\circ} \mathrm{C}\right)$, a negligible effect of nanoparticle shape and concentration was recorded. Moreover, spherical shaped nanoparticles exhibited higher viscosity compared to the whiskers shaped nanoparticle at any particular nanoparticle concentration and temperature. For example, at room temperature and $2.5 \mathrm{wt} \%$ of $\mathrm{Al}_{2} \mathrm{O}_{3}$ nanoparticle loading, spherical shaped nanoparticles showed a viscosity value of $\sim 400 \mathrm{cP}$, while whiskers shaped nanoparticle showed a viscosity of $\sim 350 \mathrm{cP}$. The authors claimed a bigger cluster diameter of the spherical particles compared to whiskers particle cluster diameter as the possible reason of the higher viscosity of spherical shaped nanoparticles as discussed by Fox et al. [60]. 


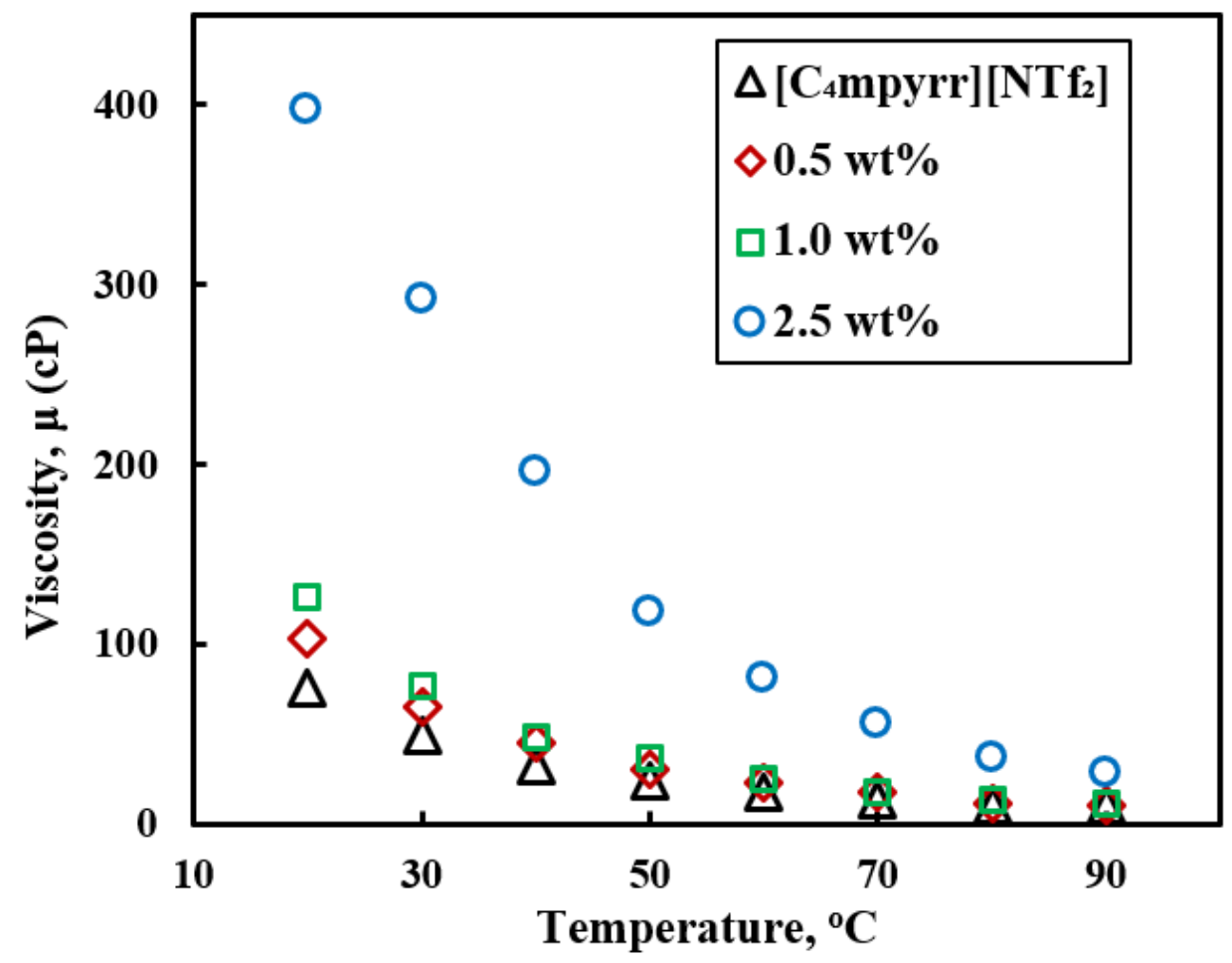

(a)

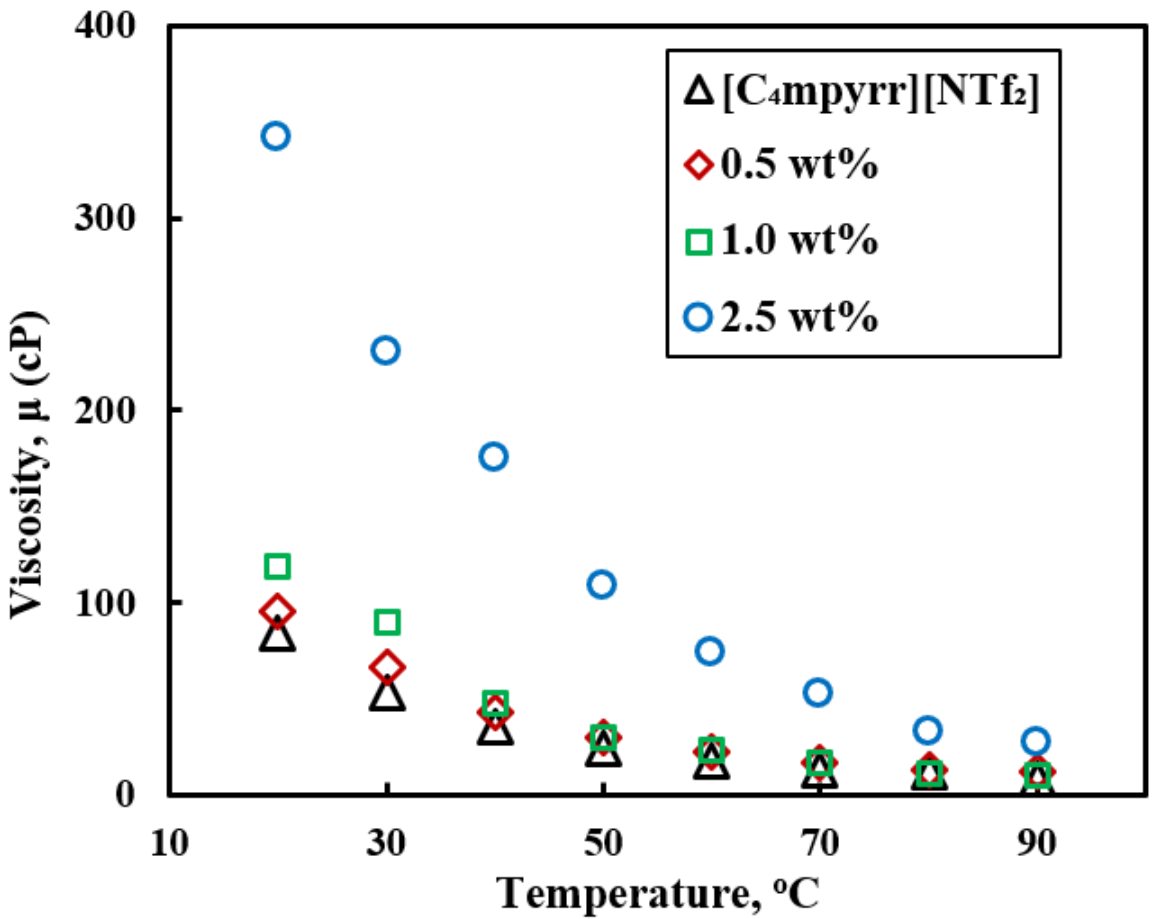

(b)

Figure 19. Effect of (a) spherical, and (b) whiskers shaped $\mathrm{Al}_{2} \mathrm{O}_{3}$ nanoparticle on viscosity of $\left[\mathrm{C}_{4}\right.$ mpyrr][NTf ${ }_{2}$ IL [84]. Reproduced with permission from [Paul], [Int. J. Heat Mass Transf.]; published by [Elsevier], 2015.

\section{Overall Comparison of Thermophysical Properties}

As discussed in Section 3, different ILs and ILs-based nanofluids combinations come with their own advantages and disadvantages. For example, ionanofluids may have significantly higher thermal conductivity but suffer from notably high viscosity/pumping 
power. Moreover, the selection of ILs-based nanofluids depends on the application specific operating conditions, such as temperature, pressure, available pumping capacity, heat source quality, etc. In order to guide readers to select appropriate ionanofluids, the three best ILs and nanofluids combinations for individual properties have been summarized in Table 8. It is worth noting that researchers studied very large combinations of ILs and ILs-based nanofluids under numerous operating conditions, i.e., temperature, nanofluid concentrations, etc. It is next to impossible to compare the thermophysical properties of ILs-based nanofluid under any common constraints. Therefore, we have selected the three best ILs-based nanofluids regardless of the operating conditions. For example, in case of density and viscosity, the three lowest reported combinations have been selected from the literature. On the contrary, in case of thermal conductivity and specific heat, the three highest reported values have been summarized. Highlighted properties in the Table 8 are considered as the best combination of thermophysical properties of ILs-based nanofluids.

Table 8. Summary of thermophysical properties of ILs-based nanofluids.

\begin{tabular}{|c|c|c|c|c|}
\hline & Property & IL-Based Nanofluids & $\begin{array}{c}\text { Temperature Range } \\
\left({ }^{\circ} \mathrm{C}\right)\end{array}$ & Ref. \\
\hline \multirow[t]{6}{*}{ Low } & \multirow{3}{*}{ Density } & {$\left[\mathrm{C}_{6} \mathrm{mim}\right]\left[\mathrm{BF}_{4}\right]+0.06 \mathrm{wt} \%$ graphene } & $30-210$ & [50] \\
\hline & & {$\left[\mathrm{C}_{2} \mathrm{mim}\right][\mathrm{DEP}]+1 \mathrm{wt} \% \mathrm{MWCNT}$} & $25-50$ & [47] \\
\hline & & {$\left[\mathrm{C}_{6} \mathrm{mim}\right]\left[\mathrm{BF}_{4}\right]+0.06 \mathrm{wt} \% \mathrm{SiC}$} & $25-65$ & [54] \\
\hline & \multirow{3}{*}{ Viscosity } & {$\left[\mathrm{C}_{4} \mathrm{mmim}\right]\left[\mathrm{NTf}_{2}\right]+2.5 \mathrm{wt} \% \mathrm{Al}_{2} \mathrm{O}_{3}$} & $25-300$ & [60] \\
\hline & & {$\left[\mathrm{C}_{6} \mathrm{mim}\right]\left[\mathrm{BF}_{4}\right]+0.06 \mathrm{wt} \%$ graphene } & $25-215$ & [50] \\
\hline & & {$\left[\mathrm{C}_{4} \mathrm{mim}\right]\left[\mathrm{BF}_{4}\right]+0.01 \mathrm{wt} \%$ graphene } & $25-150$ & [52] \\
\hline \multirow{3}{*}{ High } & \multirow{3}{*}{ Thermal conductivity } & {$\left[\mathrm{C}_{2} \operatorname{mim}\right][\mathrm{DEP}]+2 \mathrm{wt} \% \mathrm{SWCNT}$} & $30-80$ & [48] \\
\hline & & {$\left[\mathrm{C}_{4} \mathrm{mmim}^{\mathrm{m}}\right]\left[\mathrm{NTf}_{2}\right]+2.5 \mathrm{wt} \%$} & $25-60$ & [60] \\
\hline & & {$\left[\mathrm{C}_{4} \mathrm{mim}\right]\left[\mathrm{NTf}_{2}\right]+2.5 \mathrm{wt} \% \mathrm{Al}_{2} \mathrm{O}_{3}$} & $10-70$ & [62] \\
\hline \multirow{3}{*}{ Low } & \multirow{3}{*}{ Specific heat } & {$\left[\mathrm{C}_{4} \mathrm{mpyrr}\right]\left[\mathrm{NTf}_{2}\right]+2.5 \mathrm{wt} \% \mathrm{Al}_{2} \mathrm{O}_{3}$} & $25-340$ & [84] \\
\hline & & {$\left[\mathrm{C}_{4} \mathrm{mmim}\right]\left[\mathrm{NTf}_{2}\right]+2.5 \mathrm{wt} \% \mathrm{Al}_{2} \mathrm{O}_{3}$} & $25-340$ & [62] \\
\hline & & {$\left[\mathrm{C}_{6} \mathrm{mim}\right]\left[\mathrm{BF}_{4}\right]+0.06 \mathrm{wt} \% \mathrm{SiC}$} & $0-80$ & [54] \\
\hline
\end{tabular}

\section{Thermal Performance of Ionic Liquids-Based Nanofluids}

ILs-based nanofluids are mainly proposed for direct solar collector and concentrated solar collector as HTFs because of their higher thermal stability compared to other HTFs. Therefore, it is crucial to characterize the thermal performance of different ILs-based nanofluids to further enhance their effectiveness as HTFs to meet the ever-growing global energy demands. Unfortunately, very few studies have been done to characterize the thermal performance of the ILs-based nanofluids for both natural and forced convections.

\subsection{Natural Convection}

To date, very few studies of natural convection of ILs-based nanofluids have been reported [84,96,97]. For example, Paul et al. [84] experimentally studied the natural convection heat transfer characteristics of base $\left[\mathrm{C}_{4}\right.$ mpyrr] $\left[\mathrm{NTf}_{2}\right]$ ILs and ILs-based $\mathrm{Al}_{2} \mathrm{O}_{3}$ nanofluids. Figure 20 shows the schematic of their used natural convection experimental setup and corresponding experimental conditions of their investigations. 


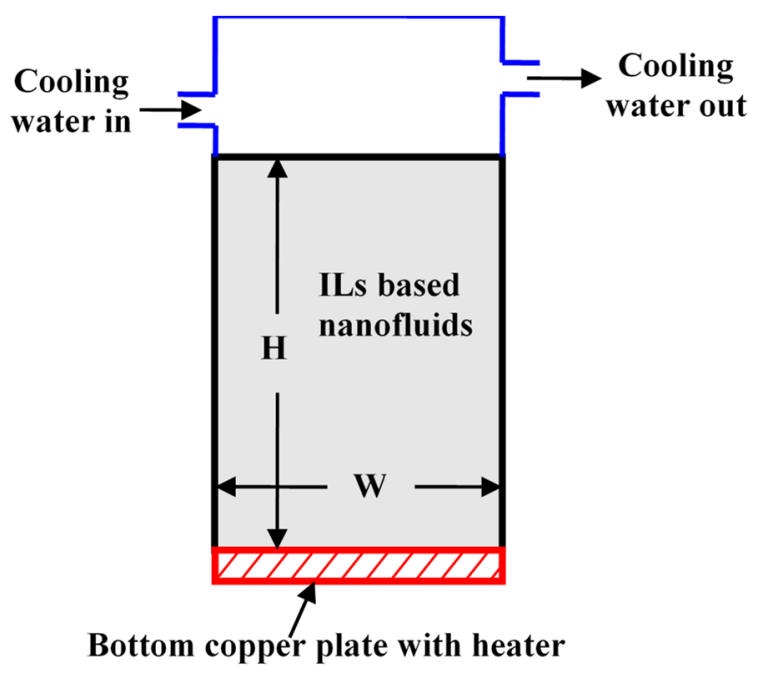

Figure 20. Schematic of experimental cavity [84]. Reproduced with permission from [Paul], [Int. J. Heat Mass Transf.]; published by [Elsevier], 2015.

Figure 21 shows the natural convection behavior of the ILs-based nanofluids containing spherical $\mathrm{Al}_{2} \mathrm{O}_{3}$ nanoparticles. From the figure, it is evident that the ILs based nanofluids have a lower Nusselt number $(\mathrm{Nu})$ compared to the base ILs, and at any Rayleigh number $(R a), N u$ decreases with nanoparticle concentration. The authors stated that the degradation of heat transfer mostly came from the enhanced viscosity of ILs-based nanofluids. Agglomeration and sedimentation of nanoparticles may play a role in creating extra resistance, and hence, reduce the $\mathrm{Nu}$ of ILs-based nanofluids compared to base ILs. Paul el al. [96] also performed a numerical investigation of ILs-based nanofluids $\left(\mathrm{Al}_{2} \mathrm{O}_{3}\right.$ nanoparticles and $\left[\mathrm{C}_{4} \mathrm{mpyrr}\right]\left[\mathrm{NTf}_{2}\right]$ ILs) in bottom wall heated enclosures. The authors found a poor heat transfer behavior of ILs-based nanofluids compared to the base ILs, but the degradation percentages were not same as in the experimental study. This is because nanoparticle sedimentation was not considered in the numerical study.

Alina et al. [97] conducted a numerical investigation to evaluate the natural convection of $\left[\mathrm{C}_{4} \mathrm{mim}\right]\left[\mathrm{NTf}_{2}\right]$ ILs with the addition of small volume concentrations of $\mathrm{Al}_{2} \mathrm{O}_{3}$ nanoparticles. A square enclosure considering two heating situations; bottom heating and lateral heating of the enclosure, were used as a computational domain. The authors compared their results of ILs-based nanofluids with conventional water-based nanofluids and found that a low concentration of ILs-based nanofluids provide superior thermal performance when compared to the water-based nanofluids, however, at higher volume concentrations, ILs provided lower $\mathrm{Nu}$ compared to the water-based nanofluids. Moreover, the authors also proposed two correlations for $\mathrm{N} u$ as a function of both $\mathrm{Ra}$ and $\phi$, for the two studied cases, in the range of $104 \leq R a \leq 106$ and $0 \% \leq \phi \leq 2.5 \%$, as shown below:

Hot element at the bottom wall:

$$
N u=81.663 \phi+0.555(R a-4614.793)^{0.226}-3710.366 \phi^{2}
$$

Hot element at the left wall:

$$
N u=116.173 \phi+0.484 R a^{0.245}-5001.894 \phi^{2}
$$




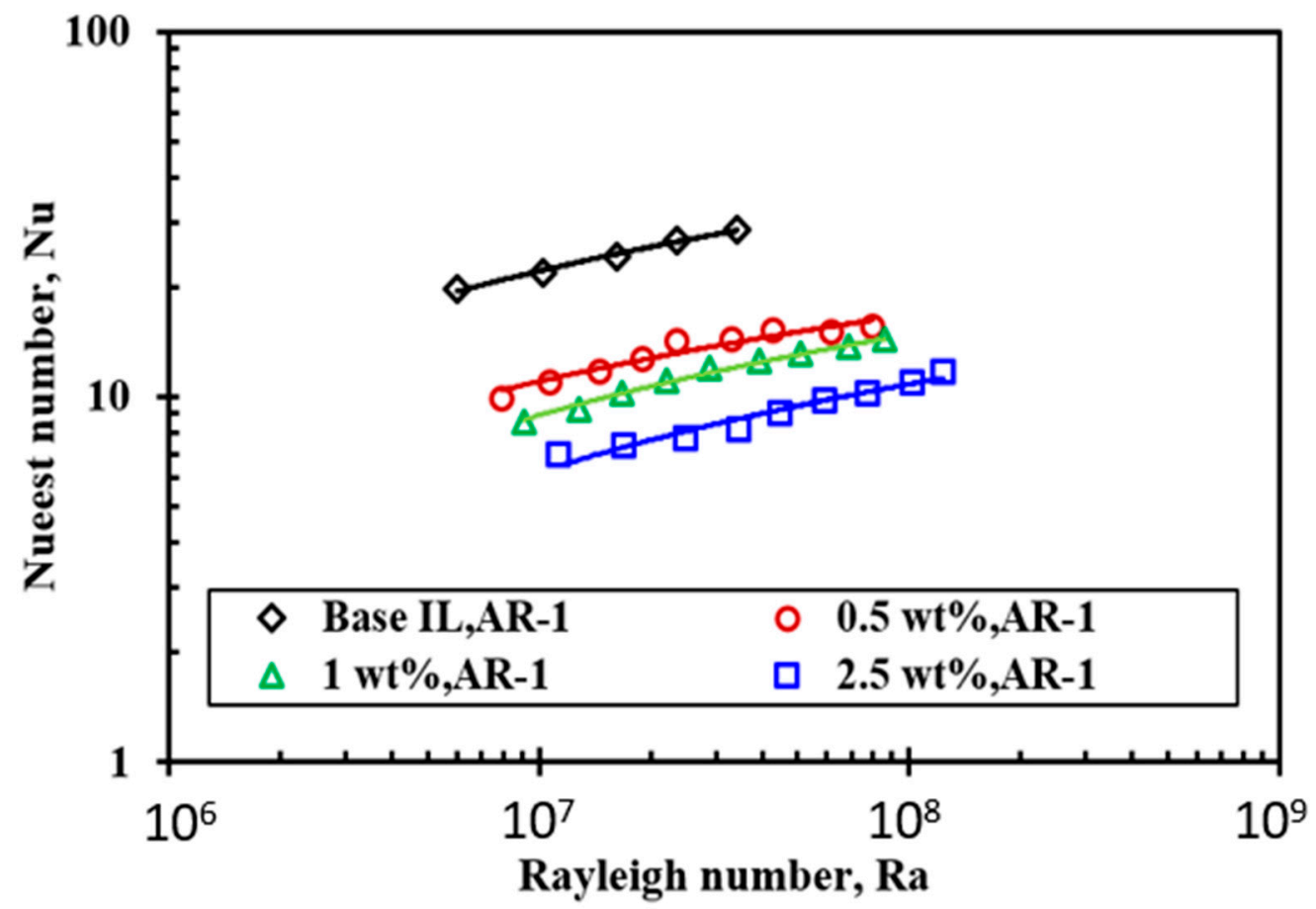

Figure 21. Natural convection heat transfer behavior of $\left[\mathrm{C}_{4} \mathrm{mpyrr}_{[}\right]\left[\mathrm{NTF}_{2}\right] \mathrm{IL}$ and ILs-based nanofluids [84]. Reproduced with permission from [Paul], [Int. J. Heat Mass Transf.]; published by [Elsevier], 2015.

\subsection{Forced Convection}

To the best of the author's knowledge, to date there has only been one experimental study of forced convection for ILs-based nanofluids, conducted by Paul el al. [49]. Figure 22 represents the schematic of the experimental setup, which consists of a pump, test section, heat exchanger, collection tank, and pressure transducer. The inner and outer diameter of the stainless-steel test sections were 3.86 and $6.35 \mathrm{~mm}$, respectively.

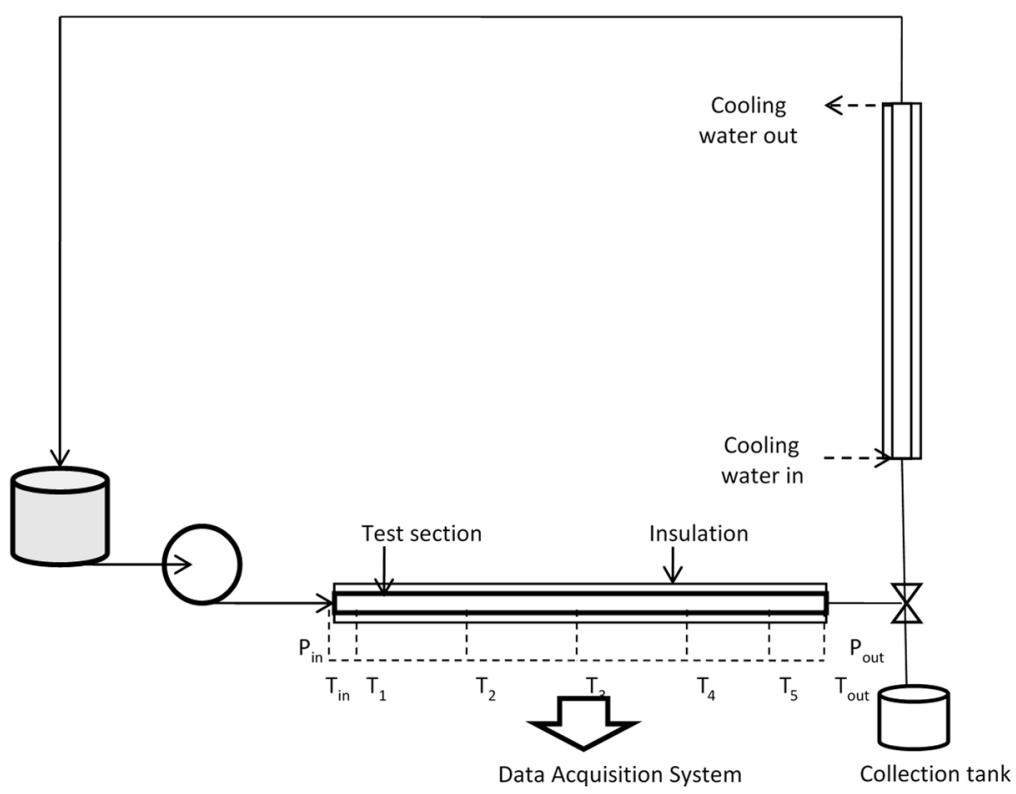

Figure 22. Schematic of the forced convection study loop [49]. Reproduced with permission from [Paul], [Int. J. Heat Mass Transf.]; published by [Elsevier], 2015. 
Figure 23 represents the heat transfer coefficient enhancement of ILs base nanofluid over the base ILs as a function of Reynolds number $(R e)$. It is clear from the figure that the heat transfer coefficient increases with nanoparticle concentration and $R e$. The maximum enhancement of heat transfer coefficient was $27 \%$ for laminar flow. The enhancement of heat transfer coefficient was due to the higher thermal conductivity of ILs-based nanofluids and ions to nanoparticles interaction.

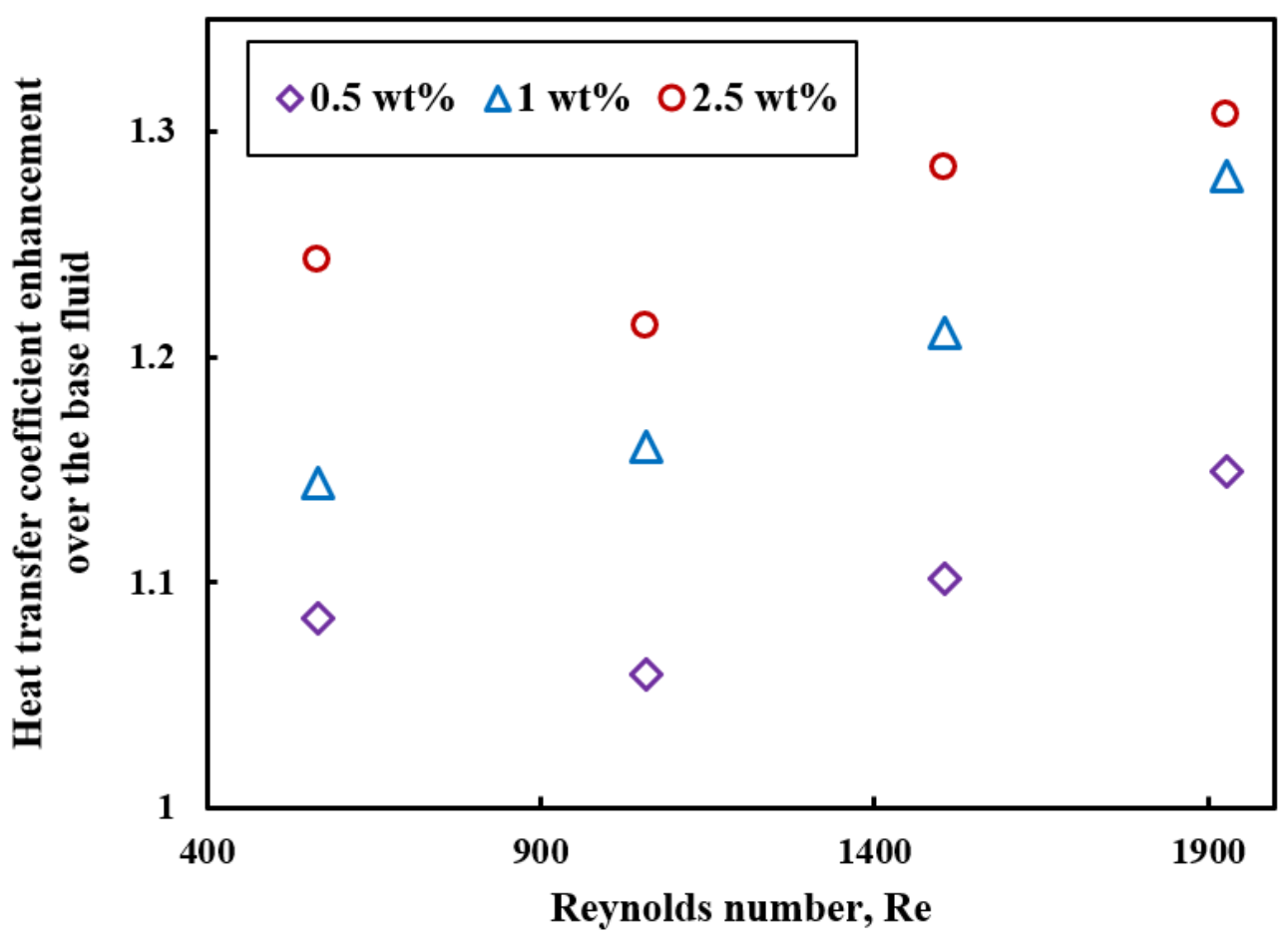

Figure 23. Forced convective heat transfer coefficient enhancement of ILs based nanofluids as a function of Reynolds number $(x / d=75.65)$ in laminar flow regime [49]. Reproduced with permission from [Paul], [Int. J. Heat Mass Transf.]; published by [Elsevier], 2015.

Paul et al. [98] conducted a numerical investigation of $\left[\mathrm{C}_{4} \mathrm{mim}\right]\left[\mathrm{NTf}_{2}\right]$ ILs-based nanofluids in a circular tube using Continuum and Eulerian based two-phase model. ILs-based nanofluids were considered as a mixture averaged single fluid in the Continuum model, however, the Eulerian based model emphasized the interaction between the nanoparticles and the base fluid. The results indicated that the Eulerian model better predicts the experimental results compared to the Continuum model. Authors also proposed an empirical model (Equation (4)) for the heat transfer behavior ILs-based nanofluids under laminar flow conditions and compared this with the experimental results (see Figure 24).

$$
N u_{N F}=30.768 \varphi^{0.1135} \operatorname{Re}^{0.3378} \operatorname{Pr}^{-0.136}\left(\frac{d}{x}\right)^{0.3713}
$$

Chereches et al. [99] performed a numerical investigation of ILs-based nanofluids comprised of $\left[\mathrm{C}_{4}\right.$ mpyrr][ $\left.\mathrm{NTf}_{2}\right]$ and $\left[\mathrm{C}_{4}\right.$ mim] $\left[\mathrm{NTf}_{2}\right]$ ILs as well as $\mathrm{Al}_{2} \mathrm{O}_{3}$ nanoparticles. The study was performed in laminar and turbulent flow regimes in a heated tube with constant heat flux. The results showed that ILs-based nanofluids have a higher heat transfer coefficient compared to the base ILs, and the thermal conductivity enhancement is one of the driving factors for the enhanced thermal performance of ILs-based nanofluids. Finally, the authors proposed a heat transfer correlation (see Equation. (5)) for ILs-based nanofluids in a laminar flow regime.

$$
N u=4.15 \operatorname{Re}^{0.09} \operatorname{Pr}^{0.195}\left(1-\varphi-200 \varphi^{2}\right)
$$


Minea et al. [100] also performed another numerical investigation of forced convection in a laminar flow region with several ILs and $\mathrm{Al}_{2} \mathrm{O}_{3}$, MWCNTs, and graphene nanoparticles, and reported a 1.7-12.1\% enhancement of heat transfer coefficients based on the type of base ILs.

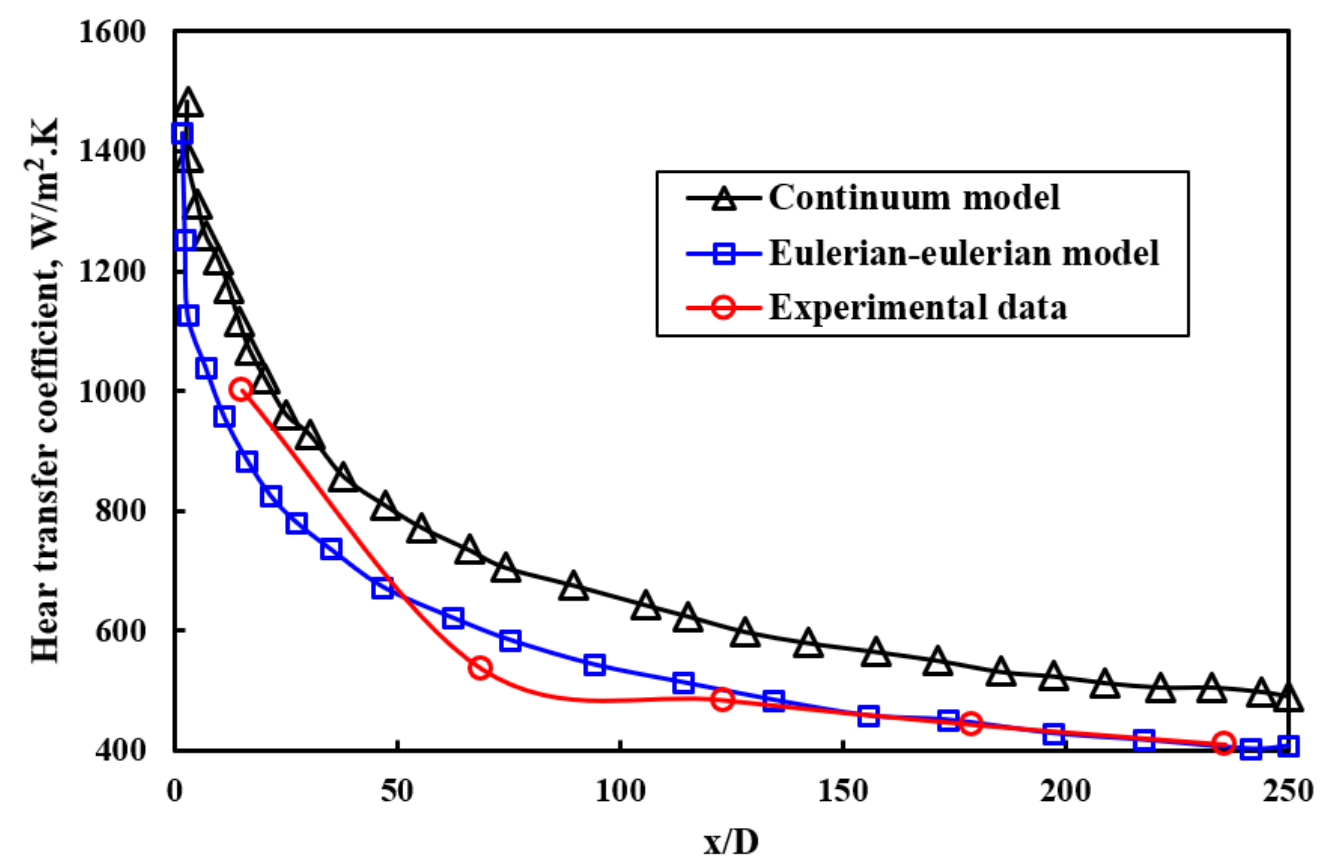

Figure 24. Comparison of two different numerical models (Eulerian vs. Continuum) for heat transfer coefficients with respect to experimental data $\left(R_{e D}=1505\right)\left(\left(\left[\mathrm{C}_{4} \mathrm{mim}\right]\left[\mathrm{NTf}_{2}\right] \mathrm{IL}\right.\right.$ and $0.36 \mathrm{vol} \% \mathrm{Al}_{2} \mathrm{O}_{3}$ nanopartcles) [98]. Reproduced with permission from [Paul], [Int. J. Heat Mass Transf.]; published by [Elsevier], 2019.

\section{Conclusions and Recommendations}

This paper summarized the recent development of ionic liquids (ILs)-based nanofluids as heat transfer fluids for solar thermal applications. The summaries are included the detailed synthesis procedure, measurement techniques, theoretical and empirical correlation, thermophysical properties (density, viscosity, thermal conductivity, and specific heat) and thermal performance (natural and forced convection). The following conclusions can be drawn from the extensive review of ILs-based nanofluids:

1. Only limited investigations of densities of ILs-based nanofluids exist. The density of ILs-based nanofluids increases compared to base ILs, as it adds highly denser nanoparticles in the base fluid. The density slightly decreases with an increase in temperature.

2. Specific heat of ILs-based nanofluids shows scattered behavior with different nanoparticles. Graphene and single walled carbon nanotubes (SWCNTs)-based nanofluids show a lower specific heat compared to the base ILs. Multiwalled carbon nanotubes (MWCNTs)-based nanofluids show detraction and enhancement in heat capacity. All of the $\mathrm{SiC}$ and $\mathrm{Al}_{2} \mathrm{O}_{3}$ nanoparticles-based nanofluids studies reported enhancement in heat capacity compared to base ILs. Enhancement in specific heat was explained by the clustering of nanoparticles and interfacial layer of ILs into nanoparticles. However, there is no clear explanation for the scattered behavior of specific heat of ILs-based nanofluids.

3. Extensive experimental investigation of the heat capacity of ILs-based nanofluids is required to better understand the detraction or enhancement in behavior of specific heat, since specific heat is one of the most important thermophysical properties for any heat storage medium. 
4. All of the studies showed enhancement in the thermal conductivity of ILs-based nanofluids compared to base ILs, and thermal conductivity increased with nanoparticle concentrations. Enhancement in thermal conductivity was explained by the interfacial layer of base ILs into the nanoparticles, and interaction between ions and nanoparticles. However, extensive studies are required to explain the phenomenon of enhanced thermal conductivity of ILs-based nanofluids.

5. All of the studies report shear thinning behavior of ILs-based nanofluids. Graphene and multiwalled carbon nanotubes (MWCNTs) show lower viscosity of ILs-based nanofluids compared to the base ILs. $\mathrm{SiC}$ and $\mathrm{Al}_{2} \mathrm{O}_{3}$ nanoparticles shows much higher viscosity of nanofluids compared to the base fluid and viscosity increases with nanoparticles concentrations. Although ILs-based nanofluids show enhanced viscosity compared to the based fluid, at high temperatures $\left(\geq 300^{\circ} \mathrm{C}\right)$ the viscosity of base ILs and ILs-based nanofluids are very low, which is beneficial as a heat transfer fluid. Enhancement in viscosity can be explained by clustering and agglomeration of nanoparticles in the ILs-based nanofluids, and those were evident with optical microscopic image and dynamic light scattering (DLS).

6. Natural convection (bottom plate heated condition) of ILs-based nanofluids shows lower heat transfer performance compared to the base ILs, because of higher viscosity and possible sedimentation of nanoparticles. However, for sidewise heating, lower concentrations of ILs-based nanofluids show a higher heat transfer coefficient compared to water-based nanofluids.

7. ILs-based nanofluids show an enhanced heat transfer coefficient in forced convection in experimental and numerical studies, and heat transfer coefficient increases with nanoparticles concentrations. One possible reason for the enhanced thermal performance of ILs-based nanofluids is high thermal conductivity, nanoparticles migration, and interactions between ion and nanoparticles. However, rigorous experimental and numerical studies are needed to explain the exact mechanism of heat transfer coefficient enhancement in ILs-based nanofluids.

\section{Future Directions}

1. Experimental measurements, empirical correlations, and conventional numerical techniques are often insufficient to explain the effect of nanoparticles on base ionic liquids. Therefore, first-principle methods, such as density functional theory (DFT) or molecular dynamics (MD) simulation tools, can be used to accurately characterize the effect of nanoparticles size, shape, and concentration on ILs-based nanofluids properties.

2. Machine learning based artificial intelligence can be utilized to characterize thermophysical properties and the thermal performance of new ILs-based nanofluids with minimal computational cost. However, machine learning tools need to be chosen wisely based on the available training data and computational resources. Molecular dynamics simulation results can be fed as training and validation data set in the machine learning/deep learning model.

3. Thermophysical properties and thermal performance of ILs-based nanofluids need to be characterized at the appropriate operating conditions, i.e., high temperature of a solar thermal power plant.

4. Overall thermal performance of ILs-based nanofluids need to be experimentally benchmarked for full-scale solar thermal power systems considering different geographical locations around the globe.

Author Contributions: Conceptualization: T.C.P., A.T., R.M., A.K.M.M.M., and A.S.S.; writingoriginal draft preparation: T.C.P., A.T., R.M., A.S.S.; review and editing: T.C.P., A.T.; supervision: J.A.K., T.C.P. All authors have read and agreed to the published version of the manuscript.

Funding: This research received no external funding.

Institutional Review Board Statement: Not applicable. 
Informed Consent Statement: Not applicable.

Data Availability Statement: Not applicable.

Acknowledgments: The financial support of this project is from Vice-President of Research, University of South Carolina under the Advanced Support for Innovative Research Excellence (ASPIRE I) program (Grant\# 17110-18-47784). The authors would like to thank Nishat Tabassum and Tahsin Tabassum at University of South Carolina for their valuable contributions for data pre-processing.

Conflicts of Interest: The authors declare no conflict of interest.

\section{Nomenclature}

$\begin{array}{lll}k & \text { Thermal conductivity } & {[\mathrm{W} / \mathrm{m} \cdot \mathrm{K}]} \\ c_{p} & \text { Heat capacity } & {[\mathrm{J} / \mathrm{g} \cdot \mathrm{K}]} \\ D & \text { Fractal index } & {[\sim]} \\ h & \text { Interfacial layer thickness } & {[\mathrm{nm}]} \\ a & \text { Average radius } & {[\mathrm{nm}]} \\ N u & \text { Nusselt number } & {[\sim]} \\ R a & \text { Rayleigh number } & {[\sim]} \\ P r & \text { Prandtl number } & {[\sim]} \\ d & \text { diameter } & {[\mathrm{m}]} \\ \mathrm{x} & \text { axial distance } & {[\mathrm{m}]} \\ \mathrm{Greek} \text { Symbols } & & \\ \gamma, \gamma_{1} & \text { Constant } & {[\sim]} \\ \rho & \text { Density } & {\left[\mathrm{kg} / \mathrm{m}^{3}\right]} \\ \mu & \text { Dynamic viscosity } & {[\mathrm{centipoise}]} \\ \phi & \text { Nanoparticle volume fraction } & {[\sim]} \\ \phi_{a} & \text { Effective volume fraction of aggregates } & {[\sim]} \\ \text { Subscripts } & & \\ I N F & \text { Ionic liquids-based nanofluids } & \\ B L & \text { Base liquid } & \\ \mathrm{n} & \text { Nanoparticle } & \\ a & \text { Aggregate } & \\ l r & \text { Interfacial layer } & \\ \mathrm{MWCNTs} & \text { Multiwalled carbon nanotubes } \\ \text { SWCNTs } & \text { Singlewalled carbon nanotubes } & \\ & & \end{array}$

\section{References}

1. Timilsina, G.R.; Kurdgelashvili, L.; Narbel, P.A. Solar energy: Markets, economics and policies. Renew. Sustain. Energy Rev. 2012, 16, 449-465. [CrossRef]

2. Kalogirou, S.A. Solar thermal collectors and applications. Prog. Energy Combust. Sci. 2004, 30, 231-295. [CrossRef]

3. Moens, L.; Blake, D.M.; Rudnicki, D.L.; Hale, M.J. Advanced Thermal Storage Fluids for Solar Parabolic trough Systems. J. Sol. Energy Eng. 2003, 125, 112. [CrossRef]

4. Rogers, R.D.; Seddon, K.R. Ionic Liquids-Solvents of the Future? Science 2003, 302, 792-793. [CrossRef]

5. Kubisa, P. Application of ionic liquids as solvents for polymerization processes. Prog. Polym. Sci. 2004, 29, 3-12. [CrossRef]

6. Wishart, J.F. Energy applications of ionic liquids. Energy Environ. Sci. 2009, 2, 956-961. [CrossRef]

7. Singh, P.; Kumari, K.; Katyal, A.; Kalra, R.; Chandra, R. Copper nanoparticles in ionic liquid: An easy and efficient catalyst for selective carba-Michael addition reaction. Catal. Lett. 2009, 127, 119-125. [CrossRef]

8. Reddy, R.G. Novel applications of ionic liquids in materials processing. J. Phys. Conf. Ser. 2009, 165, 012076. [CrossRef]

9. Jiménez, A.E.; Bermúdez, M.D. Ionic liquids as lubricants of titanium-steel contact. Part 3. Ti6Al4V lubricated with imidazolium ionic liquids with different alkyl chain lengths. Tribol. Lett. 2010, 40, 237-246. [CrossRef]

10. Web of Sciences. Available online: https://apps.webofknowledge.com/WOS_GeneralSearch_input.do?product=WOS\&search_ mode=GeneralSearch\&SID=2D1U9uF2bR6AJmsAz4a\&preferencesSaved= (accessed on 11 June 2020).

11. Ngo, H.L.; LeCompte, K.; Hargens, L.; McEwen, A.B. Thermal properties of imidazolium ionic liquids. Thermochim. Acta 2000, 357-358, 97-102. [CrossRef]

12. Yamanaka, N.; Kawano, R.; Kubo, W.; Masaki, N.; Kitamura, T.; Wada, Y.; Watanabe, M.; Yanagida, S. Dye-sensitized TiO2 solar cells using imidazolium-type ionic liquid crystal systems as effective electrolytes. J. Phys. Chem. B 2007, 111, 4763-4769. [CrossRef] [PubMed] 
13. Murray, S.M.; Zimlich, T.K.; Mirjafari, A.; O’Brien, R.A.; Davis, J.H.; West, K.N. Thermophysical properties of imidazolium-based lipidic ionic liquids. J. Chem. Eng. Data 2013, 58, 1516-1522. [CrossRef]

14. Pereiro, A.B.; Veiga, H.I.; Esperança, J.M.; Rodríguez, A. Effect of temperature on the physical properties of two ionic liquids. J. Chem. Thermodyn. 2009, 41, 1419-1423. [CrossRef]

15. Ge, R.; Hardacre, C.; Nancarrow, P.; Rooney, D.W. Thermal conductivities of ionic liquids over the temperature range from $293 \mathrm{~K}$ to 353 K. J. Chem. Eng. Data 2007, 53, 1819-1823. [CrossRef]

16. Paul, T.C.; Morshed, A.K.M.M.; Fox, E.B.; Visser, A.E.; Bridges, N.J.; Khan, J.A. Buoyancy driven heat transfer behavior of $\left[\mathrm{C}_{4} \mathrm{mim}\right]\left[\mathrm{NTf}_{2}\right]$ ionic liquid: An experimental study. Appl. Therm. Eng. 2014, 66, 534-540. [CrossRef]

17. Paul, T.C.; Morshed, A.; Fox, E.B.; Visser, A.E.; Bridges, N.J.; Khan, J.A. Thermal performance of ionic liquids for solar thermal applications. Exp. Therm. Fluid Sci. 2014, 59, 88-95. [CrossRef]

18. Shah, R.K. Thermal entry length solutions for the circular tube and parallel plates. In Proceedings of the 3rd National Heat and Mass Transfer Conference, Bombay, India, 11-13 December 1975; Indian Institute of Technology: Bombay, India, 1975 ; Volume 1. Paper No. HMT-11-75.

19. Gnielinski, V. New equations for heat and mass transfer in the turbulent flow in pipes and channels. Int. J. Chem. Eng. 1976, 16, 359-368.

20. Chen, H.; He, Y.; Zhu, J.; Alias, H.; Ding, Y.; Nancarrow, P.; Hardacre, C.; Rooney, D.; Tan, C. Rheological and heat transfer behaviour of the ionic liquid, [C4mim][NTf2]. Int. J. Heat Fluid Flow 2008, 29, 149-155. [CrossRef]

21. He, G.D.; Fang, X.M.; Xu, T.; Zhang, Z.G.; Gao, X.N. Forced convective heat transfer and flow characteristics of ionic liquid as a new heat transfer fluid inside smooth and microfin tubes. Int. J. Heat Mass Transf. 2015, 91, 170-177. [CrossRef]

22. Wang, W.; Wu, Z.; Zhang, Y.; Li, B.; Sundén, B. Thermophysical properties and convection heat transfer behavior of ionic liquid $\left[\mathrm{C}_{4} \mathrm{mim}\right]\left[\mathrm{NTf}_{2}\right]$ at medium temperature in helically corrugated tubes. Appl. Therm. Eng. 2018, 142, 457-465. [CrossRef]

23. Wadekar, V.V. Ionic liquids as heat transfer fluids-An assessment using industrial exchanger geometries. Appl. Therm. Eng. 2017, 111, 1581-1587. [CrossRef]

24. Wong, K.V.; De Leon, O. Applications of Nanofluids: Current and Future. Adv. Mech. Eng. 2010, 2, 1-12. [CrossRef]

25. Esfe, M.H.; Saedodin, S.; Mahian, O.; Wongwises, S. Thermal conductivity of Al2O3/water nanofluids: Measurement, correlation, sensitivity analysis, and comparisons with literature reports. J. Therm. Anal. Calorim. 2014, 117, 675-681. [CrossRef]

26. Sundar, L.S.; Singh, M.K.; Sousa, A.C. Investigation of thermal conductivity and viscosity of Fe3O4 nanofluid for heat transfer applications. Int. Commun. Heat Mass Transf. 2013, 44, 7-14. [CrossRef]

27. Duangthongsuk, W.; Wongwises, S. Measurement of temperature-dependent thermal conductivity and viscosity of TiO2-water nanofluids. Exp. Therm. Fluid Sci. 2009, 33, 706-714. [CrossRef]

28. Rudyak, V.Y.; Minakov, A.V. Thermophysical properties of nanofluids. Eur. Phys. J. E 2018, 41, 1-12. [CrossRef]

29. Philip, J.; Shima, P.D. Thermal properties of nanofluids. Adv. Colloid Interface Sci. 2012, 183-184, 30-45. [CrossRef]

30. Asirvatham, L.G.; Raja, B.; Lal, D.M.; Wongwises, S. Convective heat transfer of nanofluids with correlations. Particuology 2011, 9 , 626-631. [CrossRef]

31. Das, S.K.; Choi, S.U.S.; Patel, H.E. Heat transfer in nanofluids-A review. Heat Transf. Eng. 2006, 27, 3-19. [CrossRef]

32. Fard, M.H.; Esfahany, M.N.; Talaie, M. Numerical study of convective heat transfer of nanofluids in a circular tube two-phase model versus single-phase model. Int. Commun. Heat Mass Transf. 2010, 37, 91-97. [CrossRef]

33. Moghadassi, A.; Ghomi, E.; Parvizian, F. A numerical study of water based Al2O3 and Al2O3-Cu hybrid nanofluid effect on forced convective heat transfer. Int. J. Therm. Sci. 2015, 92, 50-57. [CrossRef]

34. Putra, N.; Roetzel, W.; Das, S.K. Natural convection of nano-fluids. Heat Mass Transf. 2003, 39, 775-784. [CrossRef]

35. Haddad, Z.; Abu-Nada, E.; Oztop, H.F.; Mataoui, A. Natural convection in nanofluids: Are the thermophoresis and Brownian motion effects significant in nanofluid heat transfer enhancement? Int. J. Therm. Sci. 2012, 57, 152-162. [CrossRef]

36. Bridges, N.J.; Visser, A.E.; Fox, E.B. Potential of Nanoparticle-Enhanced Ionic Liquids (NEILs) as Advanced Heat-Transfer Fluids. Energy Fuels 2011, 25, 4862-4864. [CrossRef]

37. Wittmar, A.; Ruiz-Abad, D.; Ulbricht, M. Dispersions of silica nanoparticles in ionic liquids investigated with advanced rheology. J. Nanoparticle Res. 2012, 14, 1-10. [CrossRef]

38. Francìa, J.M.P.; Vieira, S.I.C.; Lourencìo, M.J.V.; Murshed, S.M.S.; de Castro, C.A.N. Thermal conductivity of [C4mim][(CF3SO 2) $2 \mathrm{~N}]$ and [C2mim][EtSO4] and their ionanofluids with carbon nanotubes: Experiment and theory. J. Chem. Eng. Data 2013, 58, 467-476. [CrossRef]

39. Atashrouz, S.; Mozaffarian, M.; Pazuki, G. Modeling the Thermal Conductivity of Ionic Liquids and Ionanofluids Based on a Group Method of Data Handling and Modified Maxwell Model. Ind. Eng. Chem. Res. 2015, 54, 8600-8610. [CrossRef]

40. Chereches, E.I.; Minea, A.A. A Study on Few Thermophysical Properties of Ionanofluids; IAPE: Oxford, UK, 2019; ISBN 978-1-912532-05-6.

41. Chereches, I.E.; Chereches, M.; Minea, A.A. A study on specific heat of nanoparticle enhanced fluids. IOP Conf. Ser. Mater. Sci. Eng. 2019, 485, 012006. [CrossRef]

42. Alizadeh, J.; Moraveji, M.K. An experimental evaluation on thermophysical properties of functionalized graphene nanoplatelets ionanofluids. Int. Commun. Heat Mass Transf. 2018, 98, 31-40. [CrossRef]

43. Joseph, A.; Fal, J.; Żyła, G.; Mathew, S. Nanostructuring of 1-butyl-4-methylpyridinium chloride in ionic liquid-iron oxide nanofluids. J. Therm. Anal. Calorim. 2019, 135, 1373-1380. [CrossRef] 
44. Pamies, R.; Avilés, M.D.; Arias-Pardilla, J.; Carrión, F.J.; Sanes, J.; Bermúdez, M.D. Rheological study of new dispersions of carbon nanotubes in the ionic liquid 1-ethyl-3-methylimidazolium dicyanamide. J. Mol. Liq. 2019, 278, 368-375. [CrossRef]

45. Zhang, F.-F.; Zheng, F.-F.; Wu, X.-H.; Yin, Y.-L.; Chen, G. Variations of thermophysical properties and heat transfer performance of nanoparticle-enhanced ionic liquids. R. Soc. Open Sci. 2019, 6, 182040. [CrossRef] [PubMed]

46. Yu, W.; Xie, H. A Review on Nanofluids: Preparation, Stability Mechanisms, and Applications. J. Nanomater. 2011, 2012, 1-17. [CrossRef]

47. Xie, H.; Zhao, Z.; Zhao, J.; Gao, H. Measurement of thermal conductivity, viscosity and density of ionic liquid [EMIM][DEP]-based nanofluids. Chin. J. Chem. Eng. 2016, 24, 331-338. [CrossRef]

48. Li, C.; Zhao, Z.; Zhang, X.; Li, T. Simulation and Experimental Study on Thermal Conductivity of [EMIM][DEP] + H2O + SWCNTs Nanofluids as a New Working Pairs. Int. J. Thermophys. 2018, 39, 41. [CrossRef]

49. Paul, T.C.; Morshed, A.; Fox, E.B.; Khan, J.A. Thermal performance of Al2O3 Nanoparticle Enhanced Ionic Liquids (NEILs) for Concentrated Solar Power (CSP) applications. Int. J. Heat Mass Transf. 2015, 85, 585-594. [CrossRef]

50. Liu, J.; Wang, F.; Zhang, L.; Fang, X.; Zhang, Z. Thermodynamic properties and thermal stability of ionic liquid-based nanofluids containing graphene as advanced heat transfer fluids for medium-to-high-temperature applications. Renew. Energy 2014, 63, 519-523. [CrossRef]

51. Shevelyova, M.P.; Paulechka, Y.U.; Kabo, G.J.; Blokhin, A.V.; Kabo, A.G.; Gubarevich, T.M. Physicochemical Properties of Imidazolium-Based Ionic Nanofluids: Density, Heat Capacity, and Enthalpy of Formation. J. Phys. Chem. C 2013, 117, 4782-4790. [CrossRef]

52. Zhang, L.; Chen, L.; Liu, J.; Fang, X.; Zhang, Z. Effect of morphology of carbon nanomaterials on thermo-physical characteristics, optical properties and photo-thermal conversion performance of nanofluids. Renew. Energy 2016, 99, 888-897. [CrossRef]

53. Wang, F.; Han, L.; Zhang, Z.; Fang, X.; Shi, J.; Ma, W. Surfactant-free ionic liquid-based nanofluids with remarkable thermal conductivity enhancement at very low loading of graphene. Nanoscale Res. Lett. 2012, 7, 314. [CrossRef]

54. Chen, W.; Zou, C.; Li, X. An investigation into the thermophysical and optical properties of SiC/ionic liquid nanofluid for direct absorption solar collector. Sol. Energy Mater. Sol. Cells 2017, 163, 157-163. [CrossRef]

55. Nieto de Castro, C.A.; Murshed, S.; Lourenço, M.; Santos, F.; Lopes, M.; França, J. Enhanced thermal conductivity and specific heat capacity of carbon nanotubes ionanofluids. Int. J. Therm. Sci. 2012, 62, 34-39. [CrossRef]

56. Paul, T.C.; Morshed, A.M.; Khan, J.A. Nanoparticle Enhanced Ionic Liquids (NEILS) as Working Fluid for the Next Generation Solar Collector. Procedia Eng. 2013, 56, 631-636. [CrossRef]

57. Oster, K.; Hardacre, C.; Jacquemin, J.; Ribeiro, A.; Elsinawi, A. Understanding the heat capacity enhancement in ionic liquid-based nanofluids (ionanofluids). J. Mol. Liq. 2018, 253, 326-339. [CrossRef]

58. Wang, B.; Wang, X.; Lou, W.; Hao, J. Ionic liquid-based stable nanofluids containing gold nanoparticles. J. Colloid Interface Sci. 2011, 362, 5-14. [CrossRef]

59. Wang, B.; Wang, X.; Lou, W.; Hao, J. Gold-ionic liquid nanofluids with preferably tribological properties and thermal conductivity. Nanoscale Res. Lett. 2011, 6, 259. [CrossRef]

60. Fox, E.B.; Visser, A.E.; Bridges, N.J.; Amoroso, J.W. Thermophysical Properties of Nanoparticle-Enhanced Ionic Liquids (NEILs) Heat-Transfer Fluids. Energy Fuels 2013, 27, 3385-3393. [CrossRef]

61. Nieto de Castro, C.A.; Lourenc,o, M.J.V.; Ribeiro, A.P.C.; Langa, E.; Vieira, S.I.C. Thermal Properties of Ionic Liquids and IoNanofluids of Imidazolium and Pyrrolidinium Liquids. J. Chem. Eng. Data 2010, 55, 653-661. [CrossRef]

62. Paul, T.C.; Morshed, A.; Fox, E.B.; Khan, J.A. Enhanced thermophysical properties of NEILs as heat transfer fluids for solar thermal applications. Appl. Therm. Eng. 2017, 110, 1-9. [CrossRef]

63. França, J.M.P.M.; Lourenço, M.J.V.; Murshed, S.M.S.; Pádua, A.A.H.; De Castro, C.A.N. Thermal Conductivity of Ionic Liquids and IoNanofluids and Their Feasibility as Heat Transfer Fluids. Ind. Eng. Chem. Res. 2018, 57, 6516-6529. [CrossRef]

64. Liu, J.; Xu, C.; Chen, L.; Fang, X.; Zhang, Z. Preparation and photo-thermal conversion performance of modified graphene/ionic liquid nanofluids with excellent dispersion stability. Sol. Energy Mater. Sol. Cells 2017, 170, 219-232. [CrossRef]

65. Wang, B.; Hao, J.; Li, Q.; Li, H. New insights into thermal conduction mechanisms of multi-walled carbon nanotube/ionic liquid suspensions. Int. J. Therm. Sci. 2014, 83, 89-95. [CrossRef]

66. Ferreira, A.; Simões, P.; Fonseca, M.; Oliveira, M.; Trino, A. Transport and thermal properties of quaternary phosphonium ionic liquids and IoNanofluids. J. Chem. Thermodyn. 2013, 64, 80-92. [CrossRef]

67. Wang, B.; Wang, X.; Lou, W.; Hao, J. Rheological and Tribological Properties of Ionic Liquid-Based Nanofluids Containing Functionalized Multi-Walled Carbon Nanotubes. J. Phys. Chem. C 2010, 114, 8749-8754. [CrossRef]

68. Neo, C.Y.; Ouyang, J. Functionalized carbon nanotube-induced viscosity reduction of an ionic liquid and performance improvement of dye-sensitized solar cells. Electrochim. Acta 2012, 85, 1-8. [CrossRef]

69. Ho, C.; Liu, W.; Chang, Y.; Lin, C. Natural convection heat transfer of alumina-water nanofluid in vertical square enclosures: An experimental study. Int. J. Therm. Sci. 2010, 49, 1345-1353. [CrossRef]

70. Maxwell, J.C. Treatise on Electricity and Magnetism, 3rd ed.; Clarendon Press: Oxford, UK, 1891.

71. Jorjani, S.; Mozaffarian, M.; Pazuki, G. A novel Nanodiamond based IoNanofluid: Experimental and mathematical study of thermal properties. J. Mol. Liq. 2018, 271, 211-219. [CrossRef]

72. Hamilton, R.L.; Crosser, O.K. Thermal Conductivity of Heterogeneous Two-Component Systems. Ind. Eng. Chem. Fundam. 1962, 1,187-191. [CrossRef] 
73. Oster, K.; Hardacre, C.; Jacquemin, J.; Ribeiro, A.P.C.; ElSinawi, A. Thermal Conductivity Enhancement Phenomena in Ionic Liquid-Based Nanofluids (Ionanofluids). Aust. J. Chem. 2019, 72, 21. [CrossRef]

74. Bruggeman, D.A.G. Dielektrizitätskonstanten und Leitfähigkeiten der Mischkörper aus About Wiley Online Library Privacy Policy Terms of Use. Ann. Phys. 1935, 416, 636-664. [CrossRef]

75. Chen, H.; Ding, Y.; He, Y.; Tan, C. Rheological behaviour of ethylene glycol based titania nanofluids. Chem. Phys. Lett. 2007, 444, 333-337. [CrossRef]

76. Leong, K.; Yang, C.; Murshed, S. A model for the thermal conductivity of nanofluids-The effect of interfacial layer. J. Nanoparticle Res. 2006, 8, 245-254. [CrossRef]

77. Einstein, A. Eine neue Bestimmung der Moleküldimensionen. Ann. Phys. 1906, 324, 289-306. [CrossRef]

78. Brinkman, H.C. The Viscosity of Concentrated Suspensions and Solutions. J. Chem. Phys. 1952, 20, 571. [CrossRef]

79. Batchelor, G.K. The effect of Brownian motion on the bulk stress in a suspension of spherical particles. J. Fluid Mech. 1977, 83, 97-117. [CrossRef]

80. Nielsen, L.E. A Generalized Equation for the Elastic Moduli of Composite Materials. A Gen. Equ. Elastic Modul. Compos. Mater. 1970, 41, 4626-4627. [CrossRef]

81. Krieger, M.; Dougherty, T.J. A Mechanism for Non-Newtonian Flow in Suspensions of Rigid Spheres. Trans. Soc. Rheol. 1959, 3, 137-152. [CrossRef]

82. Pak, B.C.; Cho, Y.I. Hydrodynamic and Heat Transfer Study of Dispersed Fluids with Submicron Metallic Oxide Particles. Exp. Heat Transf. 1998, 11, 151-170. [CrossRef]

83. Xuan, Y.; Roetzel, W. Conceptions for heat transfer correlation of nanofluids. Int. J. Heat Mass Transf. 2000, 43, 3701-3707. [CrossRef]

84. Paul, T.C.; Morshed, A.; Fox, E.B.; Khan, J.A. Experimental investigation of natural convection heat transfer of Al2O3 Nanoparticle Enhanced Ionic Liquids (NEILs). Int. J. Heat Mass Transf. 2015, 83, 753-761. [CrossRef]

85. Cherecheş, E.I.; Pradob, J.I.; Cherecheş, M.; Minea, A.A.; Lugo, L. Experimental study on thermophysical properties of alumina nanoparticle enhanced ionic liquids. J. Mol. Liq. 2019, 291, 111332. [CrossRef]

86. Patil, V.S.; Cera-Manjarres, A.; Salavera, D.; Rode, C.V.; Patil, K.R.; De Castro, C.A.N.; Coronas, A. Ru-Imidazolium Halide IoNanofluids: Synthesis, Structural, Morphological and Thermophysical Properties. J. Nanofluids 2016, 5, 191-208. [CrossRef]

87. Sadi, M. Determination of heat capacity of ionic liquid based nanofluids using group method of data handling technique. Heat Mass Transf. 2017, 54, 49-57. [CrossRef]

88. Jang, S.P.; Choi, S.U.S. Role of Brownian motion in the enhanced thermal conductivity of nanofluids. Appl. Phys. Lett. 2004, 84, 4316-4318. [CrossRef]

89. Murshed, S.; Leong, K.; Yang, C. Enhanced thermal conductivity of TiO2—Water based nanofluids. Int. J. Therm. Sci. 2005, 44, 367-373. [CrossRef]

90. Li, H.; Wang, L.; He, Y.; Hu, Y.; Zhu, J.; Jiang, B. Experimental investigation of thermal conductivity and viscosity of ethylene glycol based ZnO nanofluids. Appl. Therm. Eng. 2015, 88, 363-368. [CrossRef]

91. Buongiorno, J.; Venerus, D.C.; Prabhat, N.; McKrell, T.J.; Townsend, J.; Christianson, R.J.; Tolmachev, Y.V.; Keblinski, P.; Hu, L.-W.; Alvarado, J.L.; et al. A benchmark study on the thermal conductivity of nanofluids. J. Appl. Phys. 2009, 106, 094312. [CrossRef]

92. Kole, M.; Dey, T.K. Thermal conductivity and viscosity of Al2O3nanofluid based on car engine coolant. J. Phys. D Appl. Phys. 2010, 43. [CrossRef]

93. Saidur, R.; Leong, K.; Mohammed, H. A review on applications and challenges of nanofluids. Renew. Sustain. Energy Rev. 2011, 15, 1646-1668. [CrossRef]

94. Zyła, G.; Fal, J.; Gizowska, M.; Witek, A.; Cholewa, M. Dynamic viscosity of aluminum oxide-ethylene glycol (Al $\left.{ }_{2} \mathrm{O}_{3}-\mathrm{EG}\right)$ nanofluids. Acta Phys. Pol. A 2015, 128, 240-242. [CrossRef]

95. Wang, X.; Heinemann, F.W.; Yang, M.; Melcher, B.U.; Fekete, M.; Mudring, A.-V.; Wasserscheid, P.; Meyer, K. A new class of double alkyl-substituted, liquid crystalline imidazolium ionic liquids-A unique combination of structural features, viscosity effects, and thermal properties. Chem. Commun. 2009, 7405-7407. [CrossRef]

96. Paul, T.C.; Morshed, A.K.M.M.; Khan, J.A. Numerical investigation of natural convection of nanoparticle enhanced ionic liquids (NEILs) in enclosure heated from below. In Proceedings of the International Conference of Mechanical Engineering ICME 2015, Dhaka, Bangladesh, 18-20 December 2015; Volume 1754. AIP Conference Proceedings.

97. Minea, A.-A.; El-Maghlany, W.M. Natural convection heat transfer utilizing ionic nanofluids with temperature-dependent thermophysical properties. Chem. Eng. Sci. 2017, 174, 13-24. [CrossRef]

98. Paul, T.C.; Mahamud, R.; Khan, J.A. Multiphase modeling approach for ionic liquids (ILs) based nanofluids: Improving the performance of heat transfer fluids (HTFs). Appl. Therm. Eng. 2019, 149, 165-172. [CrossRef]

99. Chereches, E.I.; Sharma, K.V.; Minea, A.A. A numerical approach in describing ionanofluids behavior in laminar and turbulent flow. Contin. Mech. Thermodyn. 2018, 30, 657-666. [CrossRef]

100. Minea, A.A.; Murshed, S.M.S. A review on development of ionic liquid based nanofluids and their heat transfer behavior. Renew. Sustain. Energy Rev. 2018, 91, 584-599. [CrossRef] 